\title{
ESTRATÉGIAS DE SELEÇÃO EM SOJA COM BASE NA AVALIAÇÃO EM VÁRIOS ANOS
}

\section{LUÍS CLÁUDIO PRADO}

Engenheiro agrônomo

Orientador: Prof. Dr. ISAIAS OLÍVIO GERALDI

Tese apresentada à Escola Superior de Agricultura "Luiz de Queiroz", Universidade de São Paulo, para obtenção do título de Doutor em Agronomia, Área de Concentração: Genética e Melhoramento de Plantas.

P I R A C I C A B A

Estado de São Paulo - Brasil

Abril - 1999 


\section{ERRATA}

\begin{tabular}{|c|c|c|c|c|}
\hline p. & item & linha & onde se lê & leia-se \\
\hline vi & Resumo & décima segunda & No primeiro método (I) & No primeiro método \\
\hline vi & Resumo & décima quarta & $\begin{array}{l}\text { genótipos... } \\
\text {..segundo método } \\
\text { linhagens... }\end{array}$ & $\begin{array}{l}\text { (Independente) os genótipos... } \\
\text {...segundo método (Seqüencial) as } \\
\text { linhagens... }\end{array}$ \\
\hline vii & Resumo & quarta & $\begin{array}{l}\text {...superiores pelo método II, } \\
\text { tanto... }\end{array}$ & $\begin{array}{l}\text {...superiores pelo método } \\
\text { Sequencial, tanto... }\end{array}$ \\
\hline viii & Summary & décima segunda & In the first scheme (I)... & $\begin{array}{l}\text { In the first scheme } \\
\text { (Independente)... }\end{array}$ \\
\hline vili & Summary & décima terceira & ...second scheme (II)... & ...second scheme (Sequencial)... \\
\hline $1 \mathrm{x}$ & Summary & segunda & ...method II for... & ...method Sequencial for... \\
\hline 3 & 2 & oitava & ...trabalhos e opiniőes de... & ...trabalhos e resultados de... \\
\hline 4 & 2.1 & décima terceira & ...dos Estados Unidos por... & $\begin{array}{l}\text {...dos Estados Unidos da América } \\
\text { por... }\end{array}$ \\
\hline 4 & 2.1 & vigésima sexta & $\ldots(1991 / 992) \ldots$ & $\ldots(1991 / 92) \ldots$ \\
\hline 5 & 2.1 & segunda & $\begin{array}{l}\text {...enfrenta grandes problemas } \\
\text { referentes à... }\end{array}$ & $\begin{array}{l}\text {...enfrenta um risco potencial } \\
\text { devido à... }\end{array}$ \\
\hline 5 & 2.2 .1 & vigésima segunda & Ela expressa... & $\begin{array}{l}\text { A herdabilidade no sentido restrito } \\
\text { expressa... }\end{array}$ \\
\hline 6 & 2.2 .1 & nona & ...selecionadas sobre um... & ...selecionadas sob um... \\
\hline 6 & 2.2 .1 & décima sexta & $\begin{array}{l}\text {..população, } \\
\text { cruzamentos... }\end{array}$ & $\begin{array}{l}\text {...população, realização } \mathrm{de} \\
\text { cruzamentos... }\end{array}$ \\
\hline 6 & 2.2 .1 & décima sétima & ...e utilizando ambientes... & ...e utilização de ambientes... \\
\hline 7 & 2.2 .1 & vigésima terceira & $\begin{array}{l}\text {...utilidade para obtenção da } \\
\text { estimação do progresso genético... }\end{array}$ & $\begin{array}{l}\text {...utilidade para obtenção do } \\
\text { progresso genético... }\end{array}$ \\
\hline 8. & 2.2 .2 & décima sexta & A seleção indireta também... & $\begin{array}{l}\text { A resposta à seleção indireta } \\
\text { também... }\end{array}$ \\
\hline 9 & 2.2 .2 & quinta & $\begin{array}{l}\text {...que foram } \\
\text { superiores... }\end{array}$ & $\begin{array}{l}\text {...que foram ligeiramente } \\
\text { superiores... }\end{array}$ \\
\hline 14 & 2.2 .3 & quarta & ...peso de cem sementes... & ...peso de 100 sementes... \\
\hline 14 & 2.2 .3 & nona & ...regressão conjunta... & ...regressão múltipla... \\
\hline 18 & 2.3 & primeira & ...população com $25 \%$... & $\begin{array}{l}\text {...população contendo ao redor de } \\
25 \%\end{array}$ \\
\hline 19 & 2.3 & sétima & ...soja do Paraná... & ...soja do Estado do Paraná... \\
\hline 19 & 2.4 & penúlinma & $\begin{array}{l}\text { Neste processo continuado de } \\
\text { peneiramento, a força... }\end{array}$ & Neste processo continuo a força... \\
\hline 22 & 2.4 & última & .... de grăos de em soja... & .... de gräos de soja... \\
\hline 31 & 3.3.3 & terceira & ...com as 17 linhagens... & ...com as 20 linhagens... \\
\hline 31 & 3.3 .4 & décima quinta & ...seguinte modelo: & ...seguinte modelo matemático: \\
\hline 32 & 3.3 .4 & décima & ...quadrados médios, & ...quadrados médios dos resíduos, \\
\hline 32 & 3.3.4 & décima sétima & ...é a méd & ...é o valor do... \\
\hline
\end{tabular}




\begin{tabular}{|c|c|c|c|}
\hline$p$. & item & linha & onde se lê \\
\hline 35 & 3.3 .5 & décima & $\hat{\mathbf{h}}_{\mathrm{x}}^{2}=\frac{\sigma_{\mathrm{L}}^{2}}{\sigma_{\mathrm{L}}^{2}+\frac{\sigma^{2}}{\mathrm{R}}}=\frac{\mathrm{Q}_{2}}{\mathrm{R}}$ \\
\hline 36 & 3.3 .5 & quarta & $\hat{\mathrm{h}}_{\mathrm{x}}^{2}=\frac{\sigma_{\mathrm{L}}^{2}}{\sigma_{\mathrm{L}}^{2}+\frac{\sigma_{\mathrm{LAA}}^{2}}{\mathrm{~A}}+\frac{\sigma^{2}}{R A}}=\frac{Q_{3}}{R A}$ \\
\hline 37 & 3.3 .6 & quinta & ...genética de linhagens, \\
\hline 38 & 3.3 .6 & décima quinta & $\begin{array}{l}\text {...estimativa do coefiente de } \\
\text { herdabilidade, }\end{array}$ \\
\hline 44 & 4.1 & décima segunda & ... ou a menor precisão... \\
\hline 45 & 4.3 & penúltima & $\begin{array}{l}\text { Uma população homozigótica } \\
\text { apresenta apenas um componente } \\
\text { da variância, a variância genética } \\
\text { aditiva. }\end{array}$ \\
\hline 46 & 4.3 .1 & antepenúltima & ...linhagens não apresentou... \\
\hline 50 e 51 & 4.3 .2 & página toda & $\mathrm{cm}^{2}$ \\
\hline 58 & 4.4 & vigésima terceira & $\begin{array}{l}\text { Portanto, para o caráter produção } \\
\text { de grãos, a... }\end{array}$ \\
\hline 62 & $5(a)$ & $\begin{array}{l}\text { terceira, quarta e } \\
\text { quinta }\end{array}$ & $\begin{array}{l}\text { Para ambos os caracteres ocorreu } \\
\text { interação entre genótipos e anos; } \\
\text { entretanto, esta foi bastante } \\
\text { pronunciada para a produção de } \\
\text { grãos e pouco pronunciada para a } \\
\text { altura das plantas na maturação. }\end{array}$ \\
\hline 62 & $5(\mathrm{e})$ & três últimas linhas & $\begin{array}{l}\text { O método de seleção Sequencial é } \\
\text { recomendado nos esquemas de } \\
\text { melhoramento em que a seleção é }\end{array}$ \\
\hline & & & $\begin{array}{l}\text { feita em várias etapas e os } \\
\text { genótipos estão fixados, como é o } \\
\text { caso de populaçð̃es homozigóticas } \\
\text { de espécies autógamas. }\end{array}$ \\
\hline
\end{tabular}

$\hat{h}_{\mathrm{x}}^{2}=\frac{\sigma_{\mathrm{L}}^{2}}{\sigma_{\mathrm{L}}^{2}+\frac{\sigma^{2}}{\mathrm{R}}}=\frac{\mathrm{Q}_{2}-\mathrm{Q}_{1}}{\mathrm{Q}_{2}}$
$\hat{\mathrm{h}}_{\mathrm{x}}^{2}=\frac{\sigma_{\mathrm{L}}^{2}}{\sigma_{\mathrm{L}}^{2}+\frac{\sigma_{\mathrm{LA}}^{2}}{\mathrm{~A}}+\frac{\sigma^{2}}{R A}}=\frac{Q_{3}-Q_{2}}{Q_{3}}$

...genética entre linhagens,

...valor paramétrico do

coefieciente de herdabilidade,

...ou a maior precisão...

Uma população homozigótica apresenta dois componente da variância, a variância genética aditiva e a variância epistática.

...linhagens não apresentaram...

(cm/parcela) ${ }^{2}$

Portanto, para o caráter altura das plantas na maturação, a...

(eliminar o período)

O método de seleção Seqüencial é recomendado nos esquemas de melhoramento em que a seleção é feita em várias etapas. 
Dados Internacionais de Catalogação na Publicaçāo (CIP)

DIVISÃO DE BIBLIOTECA E DOCUMENTAÇÃO - Campus "Luiz de Queiroz"/USP

\author{
Prado, Luis Cláudio \\ Estratégias de seleção em soja com base na avaliação em vários anos / Luis \\ Cláudio Prado. - - Piracicaba, 1999. \\ $92 \mathrm{p}$. \\ Tese (doutorado) - Escola Superior de Agricultura Luiz de Queiroz, 1999. \\ Bibliografia. \\ 1. Herdabilidade 2. Interação genótipico-ambiente 3. Melhoramento genético \\ vegetal 4 . Seleção genética 5 . Soja 6 . Variabilidade genética I. Título
}

CDD 633.34

"Permitida a cópia total ou parcial deste documento, desde que citada a fonte- $O$ Autor" 
Aos meus pais: Carlos Alberto Prado e Maria Lúcia Borges Prado

Irmãos: Carlos Alberto Prado Júnior e Luís Antônio Prado

Noiva: Fernanda Cerino Franco

Pessoas que trazem grande alegria à minha vida... 


\section{AGRADECIMENTOS}

- $\quad$ À Deus que me deu o dom da vida, força, fé e presença constante.

- Ao Prof. Dr. Isaias Olívio Geraldi pela amizade, orientação, confiança, apoio e colaboração neste trabalho.

- Ao CNPq pela bolsa de estudos fornecida no período de Março de 1995 a Fevereiro de 1998.

- $\quad$ À Fundação de Apoio à Pesquisa e Desenvolvimento do Oeste Baiano - Fundação BA pela colaboração na conclusão deste trabalho.

- Ao Prof. Dr. Natal Antonio Vello e equipe pelo apoio na condução dos trabalhos que geraram esta pesquisa.

- Aos professores do Departamento de Genética da ESALQ/USP, pelos ensinamentos e atenção.

- Aos funcionários do Laboratório de Soja, Fernandes Araújo e Gustavo Alexandre Perina; pelo apoio, amizade e dedicação na realização dos trabalhos de campo e laboratório.

- Às funcionárias da Biblioteca do Departamento de Genética da ESALQ, Silvana Marchizelli Gregório e Aparecida Elisabeth Santos da Silva pela atenção, amizade e presteza.

- Aos funcionários do Departamento de Genética que contribuúram para que este trabalho fosse completado. 
- Aos meus pais Carlos Alberto Prado e Maria Lúcia Borges Prado pelo carinho, paciência, estímulo e apoio indispensável, o qual tornou possível a realização deste curso.

- À minha noiva Fernanda Cerino Franco pela dedicação, apoio e, principalmente, paciência.

- A todos colegas do Curso de Pós-graduação que dividiram comigo alegrias e tristezas.

- Em especial, aos eternos amigos: Angela Félis de Almeida Lopes, Dario Rosa Mesquita Neto, Derly José Henriques da Silva, Francisco Pinheiro Lima Neto, Gilberto Ken-Iti Yokomizo, Leonardo Novaes Rossi, Luciana de Andrea Ribeiro, Luciana Santos Rodrigues, Maria Inês Fernandes Faraldo, Paulo Augusto Vianna Barroso, Rogério de Melo Costa Pinto e Rainério Meireles da Silva.

- À̀ todas pessoas que contribuíram para a realização deste trabalho. 


\section{ÍN D I C E}

Página

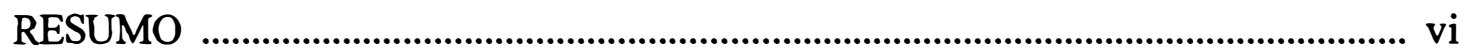

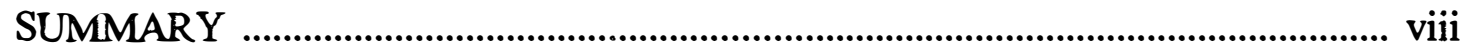

1. INTRODUÇÃO ....................................................................................... 1

2. REVISÃO DE LITERATURA …............................................................. 3

2. 1 Breve histórico da cultura da soja ................................................................ 3

2.2 Aspectos quantitativos ................................................................................ 5

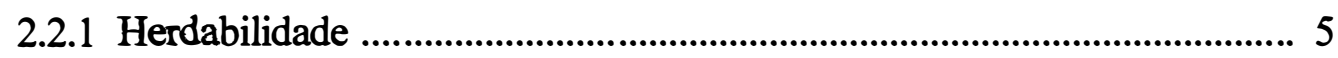

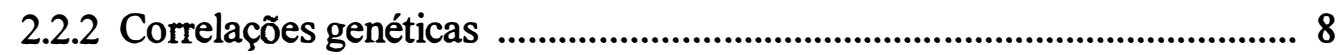

2.2.3 Interação genótipos $\mathrm{x}$ ambientes ………………................................. 11

2. 3 Melhoramento para produção de grãos ............................................................ 16

2. 4 Seleção baseada na avaliação de vários anos ................................................. 19

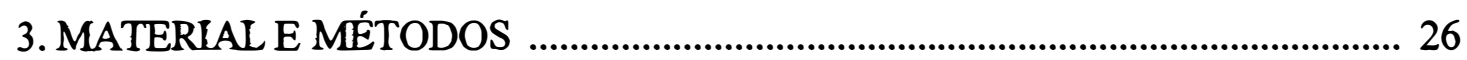

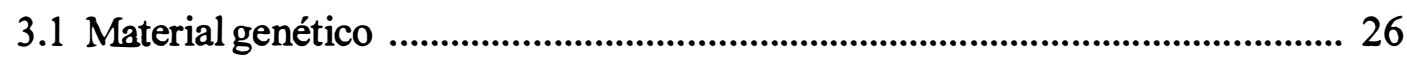

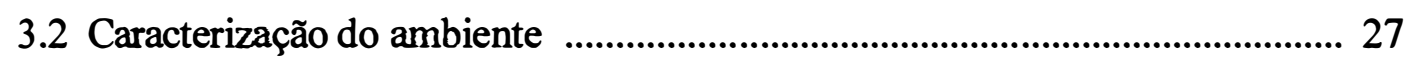

3.3 Execução experimental ................................................................................. 28

3.3.1 Delineamento e características do experimento .................................. 28

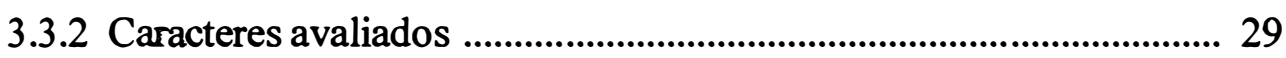

3.3.3 Métodos de seleção .................................................................... 30

3.3.4 Análises de variância ................................................................... 31

3.3.5 Estimativas dos componentes de variância e dos parâmetro

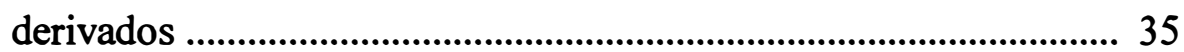

3.3.6 Intervalos de confiança associados aos parâmetros genéticos ........... 36

3.3.7 Resposta observada com seleção ...................................................... 39

4. RESULTADOS E DISCUSSÃO ..................................................................... 41

4.1 Análise geral dos dados ................................................................................. 41

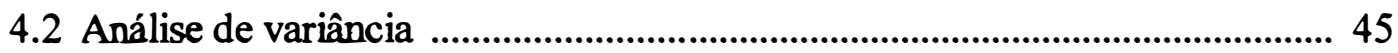

4.3 Análises genéticas ......................................................................................... 45

4.3.1 Produção de grãos ............................................................................. 46 
4.3.2 Altura das plantas na maturação ........................................................ 49

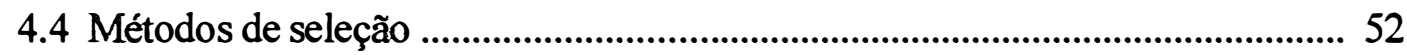

4.5 Considerações finais .................................................................................... 59

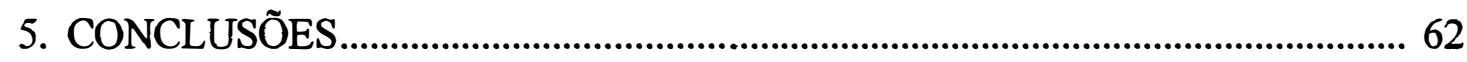

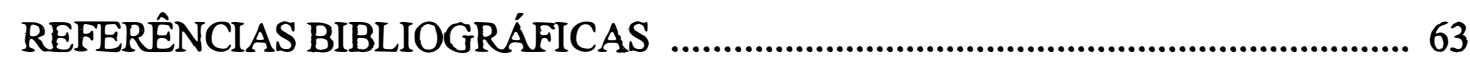

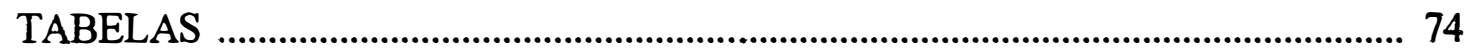




\title{
ESTRATÉGIAS DE SELEÇÃO EM SOJA COM BASE NA AVALIAÇÃO EM VÁRIOS ANOS
}

\author{
Autor: LUÍS CLÁUDIO PRADO \\ Orientador: Prof. Dr. ISAIAS OLÍVIO GERALDI
}

\section{RESUMO}

Os objetivos do presente trabalho compreendem a comparação de dois métodos de seleção em plantas autógamas, visando estabelecer estratégias que aumentem a eficiência da seleção quando esta é feita com populações homozigóticas. Isto porque a avaliação experimental dessas populações é feita em vários anos, e, desse modo, dispõe-se dos resultados da avaliação dos mesmos genótipos em vários anos.

Foram utilizadas quatro populações homozigóticas de soja oriundas de cruzamentos biparentais e conduzidas pelo método S.S.D. As quatro populações foram representadas por um número variável de linhagens, entre 78 e 100 . A avaliação foi feita em experimentos em blocos ao acaso com três repetições na área experimental do Departamento de Genética da ESALQ/USP em Piracicaba, SP, nos anos agrícolas de 1993/94, 1994/95 e 1995/96. Foram comparados dois métodos de seleção, onde a intensidade de seleção final para ambos foi de $15 \%$. No primeiro método (I) os genótipos foram selecionados com base somente na média do último ano de avaliação, enquanto que no segundo método (II) as linhagens foram selecionadas com base nas informações acumuladas dos anos de avaliação, a partir do segundo ano. Os genótipos selecionados pelos dois métodos foram avaliados no ano agrícola de 1997/98, em um experimento em blocos ao acaso com seis repetições. A eficiência de cada método foi medida pelo ganho observado com seleção em comparação com a média da população original e também com as médias de testemunhas comerciais. 
A análise estatístico genética dos dados da análise conjunta revelou a ocorrência de uma interação genótipos com anos bastante pronunciada para a produção de grãos, e menor para a altura das plantas na maturação. De maneira geral foi obtida uma frequência maior de genótipos superiores pelo método II, tanto para a produção de grãos quanto para a altura das plantas, indicando que este é mais eficiente. Esta eficiência porém foi mais acentuada nos cruzamentos onde a variabilidade genética e, consequentemente, os coeficientes de variação genético e de herdabilidade eram também menores. Estes resultados indicam que quando a seleção é feita em várias etapas e os genótipos já estão fixados, que é o que ocorre em espécies autógamas, a seleção a partir do segundo ano de avaliação deve ser feita com base nas informações acumuladas dos vários anos de avaliação. 


\title{
ALTERNATIVES FOR SELECTION IN SOYBEANS BASED ON SEVERAL YEARS OF EVALUATION
}

\author{
Author: LUÍS CLÁUDIO PRADO \\ Adviser: Prof. Dr. ISAIAS OLÍVIO GERALDI
}

\section{SUMMARY}

The objective of this work was the comparison of two schemes of selection in self-fertilizing species and to evaluate alternatives of selection schemes when it is based on homozygous populations. Generally, the experimental evaluation of the populations is carried out over several years, and consequently the results of the evaluation of the same genotypes in several years are available.

Four populations of soybeans derived from two-way crosses and advanced by the S.S.D method were used for this study. Each population was represented by a different number of inbred lines, varying from 78 to 100 . Evaluation of the populations was carried out in randomized complete block designs with three replications at Departament of Genetics, in Piracicaba, state of São Paulo, during the 1993/94, 1994/95 and 1995/96 growing seasons. Two schemes of selection were compared, where the final selection intensity for both was $15 \%$. In the first scheme (I) the selection was based only on the last year of evaluation, while in the second scheme (II) the selection was based on cumulative information across several years. The evaluation of the genotypes selected was carried out during the 1997/98 growing season in a randomized complete block design with six replications. The efficiency of both methods was evaluated by comparison of the selected genotypes with the base mean population and the controls.

Statistical and genetic analysis of experimental data in a combined analysis across the years showed a high genotype by year interaction for yield, but a 
lower effect for plant height. In general, the frequency of superior genotypes was obtained using the method II for yield and plant height, which indicated higher efficiency for this method. However, this efficiency was higher for populations where the genetic variability, and consequently the genetic variation and heritability coefficients, were smaller. General results indicated that for selection based on several steps and fixed genotypes, such as in self-fertilizing crops, selection should be based on cumulative information during several years. 


\section{INTRODUÇÃO}

A soja [Glycine $\max$ (L.) Merrill] é a mais importante oleaginosa cultivada no mundo e um dos principais produtos agrícolas para a economia nacional. $\mathrm{O}$ interesse pela cultura deve-se à quantidade nutricional de seus grãos, dada pelos conteúdos elevados de proteína e óleo, aproximadamente de $40 \%$ e $20 \%$, respectivamente, associado com a alta produtividade de grãos. Com a crescente carência alimentar pela qual passa o mundo, há a necessidade de se fornecer alimentos com alto teor protéico a baixo custo e de boa qualidade. A soja encaixa-se muito bem neste quadro, cuja proteína é utilizada principalmente para a formulação de concentrados para alimentação animal, e também, em vários produtos industriais para consumo humano.

Uma contribuição bastante significativa à agricultura tem sido dada pela pesquisa em genética e melhoramento de soja no Brasil. Os aumentos de produtividade e a expansão das fronteiras agrícolas, especialmente as áreas de cerrados (Miyasaka, 1982), são resultados inquestionáveis do benefício alcançado através da obtenção de genótipos produtivos e com grande adaptabilidade aos diferentes ambientes. $\mathrm{O}$ desenvolvimento de novos cultivares para as várias regiões de plantio de soja no país, constitui ainda uma prioridade dos programas de melhoramento, com o objetivo de fornecer aos agricultores dos diferentes ecossistemas do Brasil, as opções que melhor supram as suas necessidades.

Toledo \& Kiihl (1989) relatam que dentre os fatores limitantes ao incremento da produtividade e adaptabilidade da soja, destaca-se o pouco conhecimento dos mecanismos genéticos envolvidos no controle dos mesmos, bem como de seus componentes, causado pelas dificuldades em se realizar tais estudos. Essas dificuldades são inerentes à natureza da reprodução da soja. As metodologias desenvolvidas para a 
seleção de cruzamentos com alto potencial genético capaz de produzir populações superiores, eliminou a aleatoriedade na escolha dos materiais em relação aos caracteres quantitativos e contribuiu para tornar o melhoramento uma ciência com resultados esperados (Toledo, 1988).

Entretanto, métodos que aumentem a eficiência da seleção também devem ser investigados, visto que esta é a etapa mais demorada e mais cara em um programa de melhoramento genético. Dentro deste contexto, os objetivos deste trabalho são:

a) Avaliar a eficiência de dois métodos de seleção em soja, denominados de "Independente" e "Seqüencial" para a obtenção de genótipos superiores, em quatro populações homozigóticas de soja com graus variados de variabilidade genética para os caracteres produção de grãos e altura das plantas na maturação.

b) Relacionar os graus de eficiência destes dois métodos com as magnitudes das variâncias genéticas entre linhagens, variâncias da interação de linhagens com anos e coeficientes de herdabilidade. 


\section{REVISÃO DE LITERATURA}

Os trabalhos de melhoramento genético de qualquer espécie vegetal devem estar alicerçados no conhecimento detalhado de suas características botânicas e agronômicas e respectivos controles genéticos, bem como, principalmente, nas informações sobre a natureza e quantidade da variabilidade genética disponível para cada caráter de importância. Disso depende a escolha acertada de genitores e do método de seleção mais eficiente (Vernetti, 1983).

Nesta revisão são relatados quatro tópicos considerados essenciais para a abordagem do assunto em questão, lastreada por trabalhos e opiniões de diversos pesquisadores. Os tópicos são os seguintes: 1. Breve histórico da cultura da soja, abordando os aspectos botânicos, origem e a situação atual no Brasil e no mundo; 2. Aspectos quantitativos, ressaltando a herdabilidade, as correlações genéticas e a interação genótipos $\mathrm{x}$ ambientes, com ênfase na interação genótipos $\mathrm{x}$ anos; 3 . Melhoramento para produção de grãos, sem dúvida, o caráter de maior importância e, 4. Seleção baseada na avaliação em vários anos, tema básico deste trabalho.

\subsection{Breve histórico da cultura da soja}

A soja é uma planta autógama e anual, pertencente à família Leguminosae, subfamília Papilionoidae, tribo Phaseoleae, subtribo Phaseolinae (Glycinineae), gênero Glycine, subgênero Soja e a espécie cultivada, Glycine max (L.) Merrill, provavelmente é tetraplóide com comportamento meiótico de um diplóide normal, com $2 n=40$ cromossomos (Hadley \& Hymowitz, 1973). 
Com relação à sua origem, há ainda discordância quanto ao local exato do surgimento da soja cultivada; contudo existe um consenso que a área de origem está localizada na região leste da Ásia, e de acordo com Hymowitz (1970), a domesticação se deu por volta do século XI A.C., na região Nordeste da China. Na região centro-sul da China provavelmente localiza-se o centro primário e, na região da Manchúria, um centro secundário de diversidade genética da espécie. Li (1994), baseado em estudos arqueológicos, na atual distribuição da soja selvagem ( $G$. soja), na análise de isoenzimas e também em dados da literatura, sugeriu que a soja foi domesticada no Nordeste da China, indo desde o Noroeste de Hebei até o centro-sul do Noroeste Chinês.

Da Ásia, especificamente do Japão, a soja foi levada à Europa no século XVIII e, posteriormente, no início do século XIX, cultivares europeus foram levados à América do Norte e no fim desse mesmo século, à América do Sul (Bonetti, 1981). A soja foi introduzida no Brasil (Bahia) a partir dos Estados Unidos por Gustavo Dutra em 1882, onde encontrou condições favoráveis para seu desenvolvimento na região sul. Restrita aos estados do Rio Grande do Sul, Santa Catarina, Paraná e São Paulo, no final da década de 60 seu cultivo alcançou uma larga escala, modificando sua importância tanto no cenário nacional como no internacional. Hoje, graças aos programas de melhoramento genético, a soja é produzida do Rio Grande do Sul ao Maranhão e do Mato Grosso à Bahia (Kiihl \& Almeida, 1992).

Em termos mundiais, três países contribuem com $80 \%$ da produção da soja, sendo eles os Estados Unidos, o Brasil e a Argentina. A China tem se colocado em quarto lugar, porém a sua presença é inexpressiva no mercado econômico internacional, devido ao consumo interno de quase toda a sua produção (Miranda, 1994). Os Estados Unidos têm sua produção estabilizada ao redor dos 55 milhões de toneladas, a China, também tem estabilizado sua produção ao redor dos 12 milhões de toneladas, o Brasil, ao contrário, evoluiu de uma produção de 19,3 milhões (1991/992) para 31,4 milhões de toneladas (1997/98), isso se deve principalmente à ocupação de imensas áreas agricultáveis inexploradas (Embrapa, 1998). 
Atualmente, encontra-se muitas dificuldades em aumentar a produtividade de soja. Sabe-se que o seu cultivo no Brasil enfrenta grandes problemas referentes à limitada diversidade genética entre os cultivares com alta produtividade de grãos, tomando difícil a identificação de genótipos mais produtivos que não tenham ancestrais comuns (Hiromoto \& Vello, 1986). Baseado nisso, alguns programas de melhoramento da soja visam, principalmente, a ampliação da base genética como forma de sobrepujar patamares de produtividade e evitar o perigo de vulnerabilidade genética do germoplasma a adversidades como doenças, pragas e etc, bem como, estabelecer os melhores métodos de seleção de genótipos superiores.

\subsection{Aspectos quantitativos}

O estudo e entendimento dos caracteres quantitativos representam interesse primário para o melhorista. Os caracteres quantitativos têm sido estudados desde o início da genética em soja, com o objetivo de encontrar métodos mais eficientes de melhoramento e de seleção de linhagens superiores.

Estimativas da variância genética aditiva, do coeficiente de herdabilidade, do progresso esperado com seleção, das correlações genéticas entre caracteres de interesse, bem como, o conhecimento e entendimento da interação genótipos x ambientes, são importantes e utilizados efetivamente em programas de melhoramento de soja.

\subsubsection{Herdabilidade}

A herdabilidade de um caráter quantitativo é uma das mais importantes de suas propriedades. Ela expressa a proporção da variância total que é atribuída ao efeito médio dos genes. Portanto, a herdabilidade é usualmente definida como a parte da variância total ou fenotípica de um dado caráter, que é estritamente devida à variação genética. 
A herdabilidade é um dos parâmetros genéticos que mais contribui para o melhoramento genético, pois mede a confiabilidade do valor genotípico como indicador do valor reprodutivo. Devido a isso, a herdabilidade participa quase sempre de todas as fórmulas relacionadas com a predição de ganho genético dos diferentes métodos de melhoramento e também de inúmeras decisões práticas (Ramalho et al. 1993).

Hanson (1963) estabelece que a estimativa da herdabilidade tem duas finalidades no melhoramento genético: a primeira, indica com que facilidade diferentes características são selecionadas sobre um determinado método de seleção, e a segunda, visa a obtenção de estimativas com a finalidade de predizer ganhos com seleção. Dudley \& Moll (1969) relataram que cada estimativa de herdabilidade no melhoramento genético vegetal diz respeito especificamente à população de genótipos para a qual foi estimada. Também, cada estimativa refere-se ao conjunto particular de ambientes e condições experimentais na qual os genótipos foram testados. Dessa forma, a herdabilidade de uma certa característica não é imutável, podendo ser aumentada pela introdução de maior variação genética na população, realizando cruzamentos entre genitores bem contrastantes e utilizando ambientes mais uniformes (Lopes, 1996).

Os principais caracteres em soja apresentam altos coeficientes de herdabilidade, exceto a produção de grãos que apresenta valores de herdabilidade de menor magnitude. Para este caráter são citados a seguir, alguns exemplos: 0,35 (Johnson et al. 1955a), 0,37 (Pacova, 1992), variação de 0,16 a 0,73 (Shannon et al. 1972), variação de 0,03 a 0,58 (Brim, 1973 e Burton, 1987) e oscilação entre 0,62 ( $\left.\mathrm{F}_{6}\right)$ a $0,29\left(\mathrm{~F}_{7: 6}\right)$ (Gomes, 1995).

O coeficiente de herdabilidade do caráter teor de proteína foi estudado por Johnson et al. (1955a) e Kwon \& Torrie (1964) que encontraram valores iguais a 0,60 e 0,57 , respectivamente. Fehr \& Weber (1968) e Smith \& Weber (1968) obtiveram, valores ainda maiores, da ordem de 0,77 e 0,88 , respectivamente. Os altos valores de herdabilidade do caráter teor de proteína encontrados por Thorne \& Fehr (1970), em 
torno de 0,91 , sugerem que linhagens com altos teores de proteína podem ser selecionados a partir de populações envolvendo genitores exóticos.

O valor encontrado para o coeficiente de herdabilidade do caráter teor de óleo foi de 0,70 (Johnson et al. 1955a). Segundo os estudos realizados por Kwon \& Torrie (1964), Fehr \& Weber (1968), Smith \& Weber (1968) e Burton \& Brim (1981), os valores dos coeficientes de herdabilidade do teor de óleo oscilaram entre 0,28 e 0,89 .

Johnson \& Bernard (1963) organizaram uma tabela de herdabilidade de alguns caracteres, quando a unidade de seleção foram plantas $F_{2}$ e médias de $F_{4}$ ou linhas de gerações mais avançadas $\left(\bar{F}_{n}\right)$. A seguir, está apresentada a tabela adaptada:

\begin{tabular}{lcc}
\hline & \multicolumn{2}{c}{ Unidade de seleção } \\
\cline { 2 - 3 } Caráter & $\hat{h}^{2}\left(F_{2}\right)$ & $\hat{h}^{2}\left(F_{n}\right)^{(1)}$ \\
\hline Produção de grãos & 0,05 & 0,38 \\
Teor de proteína & 0,25 & 0,63 \\
Teor de óleo & 0,30 & 0,67 \\
\hline$(1): n \geq 4$ & &
\end{tabular}

${ }^{(1)}: n \geq 4$

As estimativas de herdabilidade dos caracteres altura de planta e número de dias para a maturação foram estudados por Brim (1973) e Burton (1987) que encontraram valores semelhantes, variando entre 0,66 a 0,90 e de 0,75 a 0,91 , respectivamente. Enquanto que, os valores obtidos por Chauhan \& Singh (1982), Freire Filho (1988), Lin \& Nelson (1988), Bonato (1989) e Gomes (1995) variaram de 0,37 a 0,99 para número de dias para a maturação. E, para o caráter altura de planta, os três primeiros autores obtiveram valores desta estimativa entre 0,31 e 0,92 .

As estimativas dos coeficientes de herdabilidade dos caracteres de interesse agronômico e/ou econômico em soja têm grande utilidade para obtenção da estimação do progresso genético esperado com seleção. Entretanto, até meados da década de 50, as estimativas de herdabilidade não estavam sendo utilizadas com esta finalidade (Johnson et al., 1955a). 


\subsubsection{Correlações genéticas}

A correlação genética é uma medida do grau de associação entre dois ou mais caracteres. O conhecimento das correlações entre os caracteres é de relevante importância no melhoramento genético de plantas, no sentido de aprimorar o material genético para um grupo de caracteres e não para caracteres isolados. Segundo Johnson et al. (1955b), o conhecimento das estimativas das correlações entre caracteres de importância agronômica e/ou econômica é fundamental tanto nas etapas de planejamento, como nas etapas de avaliação de programas de melhoramento, facilitando, dessa forma, a interpretação dos resultados e auxiliando na elaboração de programas mais eficientes no futuro.

Quando se pratica seleção em um caráter é importante saber como os demais são alterados indiretamente (Falconer, 1987). Pode-se, se a correlação entre dois caracteres for alta, selecionar um caráter e obter a resposta no outro, principalmente, se este segundo caráter apresentar dificuldade de seleção e/ou baixa herdabilidade. Essa seleção é dita indireta e pode levar a progressos mais rápidos no melhoramento (Cruz \& Regazzi, 1994). A seleção indireta também é denominada de resposta correlacionada à seleção.

As correlações genéticas de caracteres importantes no melhoramento de soja têm sido estimadas por inúmeros autores, entretanto, será dado atenção especial às correlações envolvendo o caráter produção de grãos, principalmente.

As estimativas das correlações genéticas entre os caracteres produção de grãos e teor de proteína apresentam, normalmente, valores negativos, indicando que a seleção para um caráter resulta no declínio do outro. Entretanto, os valores negativos desta correlação não têm sido muito consistentes. Johnson et al. (1955a), Kwon \& Torrie (1964) e Johnson \& Bernard (1963), encontraram correlação genética entre produção de grãos e teor de proteína da ordem de $-0,64,-0,58$ e $-0,20$, respectivamente. Holbrook et al. (1989) através de estudos realizados em diversas populações, encontraram uma variação de $-0,35$ a $-0,65$. 
Ao contrário do que normalmente ocorre, alguns autores mencionam a presença de correlação genética positiva entre produção de grãos e teor de proteína. Monteverde ${ }^{1}$, citado por Burton (1989), observou correlações iguais a 0,59, 0,50 e 0,33 entre estes caracteres, em três grupos de linhagens $F_{3}$ derivadas do cruzamento entre $o$ cultivar 'Roanoke' e três linhagens que foram relativamente superiores em produção de grãos e teor de proteína. Byth et al. (1969) e Simpson \& Wilcox, (1983) encontraram ampla variação da correlação genética entre estes dois caracteres, de 0,35 a $-0,55$ e de 0,54 a $-0,74$, respectivamente.

A ampla gama de correlações genéticas entre produção de grãos e teor de proteína, citadas na literatura, indica ser possível o desenvolvimento de cultivares com alto rendimento de grãos e com alto teor de proteína (Burton, 1984).

As correlações genéticas entre produção de grãos e teor de óleo, têm sido observadas como ligeiramente positivas ou nulas, indicando que a seleção para um caráter não interfere no desempenho do outro. Kwon \& Torrie (1964) encontraram para esta correlação um valor igual a 0,07, enquanto que, Byth et al. (1969) observaram uma variação da correlação genética entre 0,45 e $-0,03$.

A correlação genética entre teor de óleo e teor de proteína tem sido observada como negativa, por vários pesquisadores. Estimativas desta correlação foram encontradas com valores iguais a $-0,54$ (Hanson et al., 1961), -0,60 (Johnson \& Bernard, 1963), -0,66 (Kwon \& Torrie, 1964 e Miller \& Fehr, 1979), -0,80 (Hartwig, 1969). Lam-Sánchez et al. (1989), trabalhando no Brasil, encontraram valores negativos da ordem de $-0,24$. Outros autores encontraram uma ampla oscilação dos valores da correlação entre estes dois caracteres. Weiss et al. (1952), obtiveram variação das estimativas de $-0,26$ a $-0,74$, Johnson et al. (1955b) encontraram variação de $-0,48$ a $-0,70$, e Simpson \& Wilcox (1983) obtiveram valores entre -0,15 e -0,96.

1 MONTEVERDE, E. Phenotypic and genotypic correlations between yield, protein and oil contents and others caracters in soybean (Glycine max). Revista de Facultad de Agronomia, Universidad Central de Venezuela v.13, p.183-214. 1984. 
Shannon et al. (1972) estudaram seis populações de soja derivadas do cruzamento de quatro linhagens, sendo duas de alta produção de grãos (PG-1 e PG-2) e duas de alto teor de proteína (TP-1 e TP-2). Os valores das correlações genéticas entre os três caracteres de maior importância econômica, produção de grãos, teor de proteína e teor de óleo (TO) estão apresentadas no quadro a seguir. Entre outros aspectos, constatou-se que nas populações derivadas de alguns cruzamentos havia correlação genética positiva ou nula entre produção de grãos e teor de proteína, indicando a possibilidade de seleção de genótipos superiores para estes dois caracteres.

\begin{tabular}{lllccc}
\hline Populações & \multicolumn{3}{c}{ Correlações Genéticas } \\
\cline { 2 - 6 } & & PG X TP & PG X TO & TP X TO \\
\hline TP-1 & X & TP-2 & $-0,28$ & 0,24 & $-0,64$ \\
TP-1 & X & PG-1 & & & $-0,62$ \\
TP-1 & X & PG-2 & $-0,07$ & 0,07 & $-0,92$ \\
TP-2 & X & PG-1 & $-0,05$ & 0,21 & $-0,46$ \\
TP-2 & X & PG-2 & $-0,55$ & 0,08 & $-0,57$ \\
PG-1 & X & PG-2 & 0,61 & $-0,08$ & $-0,62$ \\
\hline
\end{tabular}

Sebern \& Lambert (1984) estudando duas gerações de endogamia $\left(\mathrm{F}_{4}\right.$ e $\mathrm{F}_{5}$ ) de duas populações de soja (A e B) oriundas de cruzamentos biparentais, obtiveram estimativas das correlações genéticas entre os três mais importantes caracteres da cultura da soja, sintetizadas no quadro abaixo. Os valores encontrados, indicam a dificuldade do desenvolvimento de um cultivar com alta produção de grãos e também, com alto teor de proteína, e o comportamento diferenciado nas populações com relação à estimativa das correlações entre produção de grãos e teor de óleo.

\begin{tabular}{cccc}
\hline \multirow{2}{*}{ População / Geração } & \multicolumn{3}{c}{ CORRELAÇÕES GENÉTICAS } \\
\cline { 2 - 4 } & PG X TP & PG X TO & TP X TO \\
\hline População A & & & \\
$\mathrm{F}_{4}$ & $-0,23$ & $-0,39$ & $-0,44$ \\
$\mathrm{~F}_{6}$ & $-0,58$ & $-0,02$ & $-0,18$
\end{tabular}

População B

$\begin{array}{llll}\mathrm{F}_{4} & -0,25 & 0,29 & -0,11 \\ \mathrm{~F}_{6} & -0,47 & 0,17 & -0,20\end{array}$


Estudos de correlações entre os caracteres produção de grãos e número de dias para a maturação, geralmente apresentaram estimativas de correlação genéticas positivas, de magnitude alta: 0,85 (Freire Filho, 1988); 0,86 (Santos, 1994); 0,72 (Prado, 1994); 0,86 (Gomes, 1995); 0,82 (Lopes, 1996).

Em relação aos caracteres produção de grãos e altura da planta na maturação, vários autores obtiveram estimativas de correlação genéticas positivas (Johnson et al. 1955b; Weber \& Morthy, 1952; Anand \& Torrie, 1963; Bays, 1975; Prado, 1994; Santos, 1994; Gomes, 1995; Lopes, 1996).

Em geral, há uma grande variação entre as estimativas de correlações genéticas entre os principais caracteres em soja; isso é importante porque mostra diferenciação entre o grau de associação dos caracteres de uma população para outra. É lógico que com o acúmulo de informações, tem-se um indicativo da direção e magnitude predominante da correlação entre os caracteres; contudo os coeficientes de correlação genética devem ser mensurados em cada população que está sendo estudada para poder proporcionar maior eficiência na seleção.

\subsubsection{Interação genótipos $\mathrm{x}$ ambientes}

Romagosa \& Fox (1994), definiram a interação genótipo x ambiente como a expressão genotípica diferencial através de diferentes ambientes. Esta expressão diferencial reduziria a associação entre os valores fenotípicos e genotípicos, e pode determinar que materiais selecionados como adequados para um ambiente podem não ser adequados em outros, forçando os melhoristas de plantas a examinar a adaptação genotípica dos materiais em cada ambiente. Segundo Allard \& Bradshaw (1964), os efeitos ambientais contribuem nas diferenças de comportamento observadas nos genótipos e podem ser divididos em duas categorias: (1) a que envolve fatores previsíveis e (2) a que envolve os fatores imprevisíveis. 
Variação previsível é devido àquelas condições passíveis de controle, ou seja, os efeitos obtidos devido a ambientes de casa de vegetação, câmaras de crescimento, efeito de irrigação, adubação, métodos de colheita empregados, além de qualquer outro fator no qual o pesquisador possa exercer controle. Os fatores que apresentam características permanentes durante o passar dos anos, também são considerados previsíveis, por exemplo, o fotoperíodo, o tipo de solo, o relevo, a presença de patógenos endêmicos em determinadas épocas do ano. As variações imprevisíveis compreendem as condições relacionadas geralmente a fatores climáticos, como pluviosidade atípica em alguns anos, oscilações de temperatura e qualquer outro fator que não se pode prever a sua ocorrência com segurança.

Fehr (1987), definiu uma série de prioridades referentes à interação genótipo $\mathrm{x}$ ambiente que deveriam ser consideradas pelos melhoristas: a) A necessidade de se desenvolver cultivares para fins específicos estaria determinada por um adequado entendimento da interação dos genótipos com os fatores ambientais previsíveis; b) $\mathrm{A}$ necessidade potencial de gerar um único cultivar adaptado às diferentes áreas geográficas requer um conhecimento exaustivo das interações genótipo x localidade. A importância desta interação pode determinar a necessidade de se subdividir uma ampla área geográfica em subáreas, com a finalidade de se testar novos genótipos e obter dados da performance dos mesmos que possam ser empregados pelos produtores; c) A efetiva disponibilidade de recursos para se testar ou avaliar genótipos através de diferentes localidades e anos deverá basear-se na importância relativa das interações genótipo $\mathrm{x}$ local, genótipo $\mathrm{x}$ ano e genótipo $\mathrm{x}$ local $\mathrm{x}$ ano, e d) As respostas dos genótipos em relação à variável nível de produtividade entre ambientes possibilita um entendimento de sua estabilidade. Isto permite determinar quais genótipos se comportam de forma mais adequada nos ambientes que apresentam flutuações nas condições de crescimento da cultura.

A medição da interação genótipo $x$ ambiente é importante para determinar uma estratégia ótima de melhoramento, com a finalidade de desenvolver genótipos específicos para determinados ambientes em particular. De forma geral, o 
termo genótipo $\mathrm{x}$ ambiente inclui tanto a variação espacial como a temporal, ou seja, pode compreender diferentes locais e diferentes períodos de tempo, tais como meses e anos (Gieco, 1997). O ambiente é um termo geral que inclui uma série de condições sob as quais as plantas crescem, e pode envolver sítios ou locais, anos, práticas culturais ou de manejo, ou a combinação de todos esses fatores. Comumente cada local e ano é considerado um ambiente diferente.

Existem caracteres em soja que, sem dúvida, interagem mais fortemente com as variações do ambiente. A seguir serão apresentados uma série de trabalhos que foram desenvolvidos em soja com a finalidade de avaliar as interações genótipos $\mathrm{x}$ anos e suas implicações nos esquemas seletivos.

Entre eles destacam-se os realizados por Erickson et al. (1982), os quais avaliaram 115 famílias $\mathrm{F}_{3}$ provenientes do cruzamento de Glycine max (L.) Merrill. x Glycine soja Sieb \& Zucc., com a finalidade de registrar os efeitos das interações genótipo $\mathrm{x}$ ambiente sobre o conteúdo de proteína das sementes. Os autores avaliaram 15 famílias $F_{3}$ em dois locais e dois anos, onde o componente de variância estimado para famílias foi altamente significativo $(p<0,01)$. As estimativas dos componentes de variância para as interações família $\mathrm{x}$ ano e família $\mathrm{x}$ local não foram significativas, enquanto que o componente família $\mathrm{x}$ localidade $\mathrm{x}$ ano foi significativo. Um trabalho similar foi conduzido por Xiangxun et al. (1992), onde os autores analisaram a variação do conteúdo de proteína e óleo ao longo dos anos e localidades em quatro cultivares de soja, em três anos de avaliação. Com relação aos caracteres estudados, os resultados da análise da variância demonstraram que os efeitos de cultivar, ano, localidade e a interação ano $\mathrm{x}$ localidade foram altamente significativos. Os autores também detectaram que o fator localidade teve um efeito maior que o fator ano sobre o conteúdo de proteína, óleo e proteína + óleo. Os componentes de variância devido ao efeito dos locais foram consistentemente maiores do que os observados para anos, desse modo esses caracteres apresentam uma interação significativa influenciando os resultados dos programas de seleção. 
Gupta et al. (1982a) estudando a interação genótipos x ambientes em soja, com análise de regressão individual para vários caracteres, encontraram interação significativa para a produção de sementes por planta, vagens formadas por planta, sementes por vagem, peso de cem sementes, número de dias para atingir a maturidade e número de dias para o início do florescimento. Para os componentes estruturais como altura da planta na maturidade, número de nós por planta, comprimento do internódio, comprimento do pecíolo e número de nós na haste principal, foram poucos os genótipos testados em que a interação não foi observada.

Realizando uma análise de regressão conjunta para a produção de sementes e seus componentes, Gupta et al. (1982b) observaram a ocorrência de interação significativa, também por este método, para todos os caracteres estudados, excetuandose apenas o comprimento da vagem e o número de sementes por vagem.

Outro aspecto de importância a ressaltar foi o fato de que numa série de trabalhos realizados em diversas culturas, não foram detectadas interações genótipos $\mathrm{x}$ locais, enquanto foram detectadas interações significativas genótipos $\mathrm{x}$ anos. Entre tais trabalhos podem ser relacionados os seguintes: Rasmusson \& Lambert (1961) trabalhando com cevada (Hordeum vulgare L.), verificaram que os componentes de variância estimados para genótipos $\mathrm{x}$ anos $\mathrm{e}$ genótipos $\mathrm{x}$ locais $\mathrm{x}$ anos foram significativos nos ensaios de produtividade, enquanto o componente genótipos $\mathrm{x}$ locais não foi significativo.

Elgersma (1990), estudou o caráter produtividade de sementes em nove cultivares de centeio perene (Lolium perenne L.), em um esquema de plantas espaçadas. A variação genotípica dentro de cultivares para os componentes da produtividade e outros caracteres de importância agronômica foram registrados em quatro ambientes e empregando clones como repetições. $\mathrm{O}$ autor detectou uma variação elevada dentro e entre cultivares para a maioria dos caracteres avaliados. Foram encontradas interações significativas cultivar $\mathrm{x}$ anos para a maioria dos caracteres, enquanto não foram detectadas interações significativas cultivar $\mathrm{x}$ locais. 
Yang \& Baker (1991) caracterizaram as interações genótipos $\mathrm{x}$ ambientes em cinco caracteres quantitativos de dois cruzamentos em trigo (Triticum aestivum $\mathrm{L}$.). A partir de cada uma das 48 famílias $F_{2}$ derivaram três linhas $F_{3}$, as quais foram avaliadas em $F_{5}$ (1986) e $F_{6}$ (1987), em um único local. Os autores empregaram um delineamento em parcelas subdivididas, avaliando os caracteres dias para florescimento, altura da planta, número de grãos por panícula, peso de grãos e resistência dos grãos à quebra. Eles detectaram variações significativas entre e dentro de famílias $F_{2}$ em ambos cruzamentos e para todos os caracteres avaliados. Foram também detectadas interações significativas famílias $\mathrm{x}$ anos para todos os caracteres exceto para resistência à quebra dos grãos no primeiro cruzamento, e para os caracteres dias para florescimento, grãos por panícula e resistência à quebra dos grãos, no segundo cruzamento. Também detectaram interações significativas linhagens $\mathrm{x}$ anos para $\mathrm{o}$ caráter resistência à quebra dos grãos, no segundo cruzamento.

No processo de melhoramento genético de plantas, a seleção deve estar livre da interação genótipos $\mathrm{x}$ anos, pois no caso de sua existência, há a possibilidade do melhor genótipo em um ano não apresentar o mesmo desempenho nos anos seguintes. Este fato influencia negativamente a avaliação e seleção de linhagens superiores; consequentemente, o ganho com seleção estará superestimado. Para a resolução deste problema, há a necessidade um método adequado de avaliação e seleção para se obter a melhor linhagem de um programa de cruzamentos. Nos últimos 40 anos, produziu-se cultivares com maior potencial genético de produção, adaptados às práticas culturais modernas, além de incorporação de resistência às pragas e doenças, com um aumento da qualidade das sementes; contudo esses sucessos do passado não fornecem necessariamente, provas conclusivas da eficiência dos procedimentos tradicionais de seleção no melhoramento genético atual (Brim, 1973). 


\subsection{Melhoramento para produção de grãos}

O melhoramento genético para a produção de uma cultura agrícola pela adoção de novos cultivares envolve três etapas básicas: a produção de populações segregantes e/ou novas linhagens, a seleção e avaliação para determinar a(s) melhor(es) linhagem(s) e, a multiplicação de sementes ou outras partes vegetativas para atender a demanda comercial (Finney, 1958).

O principal objetivo dos programas de melhoramento genético de soja têm sido o aumento da produtividade de grãos. Na busca desse objetivo, os programas têm desenvolvido cultivares com grande potencial genético, que são adaptados às modernas práticas culturais. Contudo, segundo Fehr (1987), o progresso genético diminuiu desde a época em que se iniciou a obtenção de cultivares por hibridação. Luedders (1977) observou que o primeiro ciclo de cultivares, a partir de cruzamentos, proporcionou maior ganho na produção do que os ciclos subsequentes. Esses resultados refletem a dificuldade em superar os progressos genéticos já obtidos com os cultivares que estão bem adaptados. Atingidas altas produtividades, torna-se mais difícil incrementar ganhos com a mesma velocidade. No Brasil, segundo Toledo et al. (1990), a ampliação do número de cultivares disponíveis nas áreas tradicionais de plantio alcança níveis de alta complexidade, devido à presença de cultivares bem adaptados e à multiplicidade de objetivos a atingir para substituí-los.

Um dos fatores que tem contribuído para a problemática envolvida na busca de materiais genéticos superiores é a quantidade limitada de diversidade genética entre cultivares com alta produtividade de grãos usados como genitores no melhoramento de soja. Assim, é crescente a dificuldade para identificar genótipos de alta produtividade que não tenham ancestrais comuns; consequentemente, tornando-se difícil a obtenção de ampla variabilidade genética nos cruzamentos destes materiais. St. Martin (1982) examinou as genealogias de 27 cultivares públicos dos grupos de maturação $00 \mathrm{a}$ IV que foram lançadas entre 1976 a 1980. O coeficiente de parentesco entre os cultivares variou de 0,06 a 0,76 com uma média de 0,25 . Ele concluiu que o melhoramento de soja 
tinha aumentado substancialmente a produtividade, no decorrer dos últimos 50 anos, à custa da perda de uma porção considerável da variabilidade genética originalmente disponível. De acordo com Fehr (1987), esta conclusão poderia ser aplicada igualmente aos cultivares de todos os grupos de maturação, não importando se eles eram de origem pública ou privada. Estudo semelhante foi feito por Vello et al. (1988) com 69 cultivares, cujos coeficientes de parentesco variaram de 0 a 1 . Com base na média geral dos 2.346 coeficientes de parentesco $(0,16)$, verificaram que o programa de melhoramento de soja no Brasil seria considerado como uma população de tamanho efetivo relativamente baixo ( $\mathrm{Ne}=11$ a 15$)$. Por outro lado, Hiromoto \& Vello (1986), traçaram as genealogias dos 74 cultivares de soja recomendados para cultivo no Brasil em 1983/84 e constataram que a base genética do germoplasma cultivado era estreita, sendo que apenas 11 ancestrais contribuíram, em conjunto, com $89 \%$ do conjunto gênico dos cultivares brasileiros. Esses autores enfatizaram a necessidade de se ampliar a base genética dos cultivares brasileiros de soja, com a finalidade de sobrepujar patamares de produtividade e evitar o perigo de vulnerabilidade genética dos cultivares.

Genótipos introduzidos estão sendo usados como genitores para o desenvolvimento de populações na tentativa de aumentar a diversidade genética dos cultivares. Vello et al. (1984) compararam populações de soja intercruzadas desenvolvidas a partir de 40 genótipos introduzidos e 40 cultivares de alta produção. Populações tendo $25 \%, 50 \%, 75 \%$ e $100 \%$ de genótipos introduzidos como genitores, tiveram a média de produtividade e a freqüência de segregantes com alta produtividade, mais baixas do que a população desenvolvida a partir de cultivares muito produtivos. Todas as quatro populações tendo genitores introduzidos mostraram aproximadamente 0 dobro da variabilidade genética para produtividade de grãos, comparativamente com a população sintetizada somente com genitores adaptados. A utilização de genótipos introduzidos não proporcionou aumentos na produtividade média populacional e nem na freqüência de linhagens superiores que suplantassem aqueles obtidos por cruzamentos entre cultivares bastante produtivos. Entretanto, aumentou consideravelmente a variabilidade genética para produção de grãos, indicando a importância da utilização da 
população com $25 \%$ de genótipo introduzido, que aumenta a variabilidade genética para o caráter em questão sem muito prejuízo da média.

Toledo et al. (1990) traçaram estratégias para a resolução dos problemas que os melhoristas de soja enfrentam na busca de eficiência. Estas estratégias envolvem, além da análise dos critérios de escolha dos genitores dos cruzamentos, a avaliação dos métodos de condução e seleção das populações segregantes e dos testes de linhagens, e o estudo do controle genético da produtividade de grãos e sua reação ao ambiente.

A seleção recorrente é um método de melhoramento que, em síntese, envolve a obtenção das progênies, sua avaliação e o intercruzamento apenas das melhores. Os genótipos selecionados de uma população são novamente intercruzados, possibilitando que uma combinação genotípica desejada venha a ocorrer via recombinação, incluindo-se quebra de blocos gênicos, além de permitir a presença de variabilidade em ciclos posteriores. Assim, através de ciclos de seleção sucessivos, aumenta-se a freqüência dos alelos favoráveis e a oportunidade de identificar linhagens puras contendo a maioria desses alelos. O referido método, que é mais comumente utilizado em plantas alógamas, tem sido empregado no melhoramento de populações de soja visando aumento da produtividade, mas os resultados obtidos ainda não são suficientes para se avaliar toda a sua potencialidade teórica. Sumamo \& Fehr (1982) observaram inconsistência na resposta, após três ciclos de seleção, entre os genótipos genitores dos ciclos de maturidade precoce, intermediário e tardio; ocorreu um aumento linear significativo na produtividade de aproximadamente $120 \mathrm{~kg} /$ ha por ciclo na média dos genótipos precoces, $24 \mathrm{~kg} / \mathrm{ha}$ por ciclo para os tardios, mas nenhuma mudança significativa na média da produtividade dos genótipos intermediários. Rose et al. (1992) obtiveram progresso satisfatório na avaliação do potencial da seleção recorrente para melhorar a produtividade de grãos numa população de soja; o ganho médio por ciclo foi de $128 \mathrm{~kg} / \mathrm{ha}$, ou 5,4\% da produtividade da população básica. Para Wilcox (1994), o método tem sido usado com sucesso limitado para aumentar a produtividade de grãos; contudo, tem proporcionado resultados promissores no desenvolvimento de linhagens 
precoces ou com alto teor de proteína nas sementes. Uma estratégia combinando preservação, ampliação e uso de germoplasma, com objetivo de associar a síntese de populações de soja com base genética ampla com a prática de seleção recorrente para caracteres de importância econômica, inclusive a produtividade de grãos, está sendo desenvolvida no Departamento de Genética da ESALQ/USP (Vello, 1992).

Toledo et al. (1990) avaliando o ganho do programa de melhoramento genético de soja do Paraná, concluiu que deverão ser atingidos índices de progressos superiores aos anteriormente obtidos, pela utilização de técnicas de genética quantitativa que analisem o desempenho das várias etapas do melhoramento e identifiquem aquelas passíveis de aperfeiçoamento. Esta conclusão deve ser válida para todos os programas de melhoramento de soja.

\section{4 Seleção baseada na avaliação em vários anos}

A soja é uma cultura que tem se expandindo para novas fronteiras agrícolas, aumentando sua área de plantio e desta forma gerando maiores divisas econômicas para o Brasil. Deste modo, estudos para potencializar ao máximo sua produtividade é de grande importância aos agricultores.

Buscando fornecer subsídios para a discussão sobre a eficiência do método de seleção baseada na avaliação em vários anos na recomendação de cultivares, fez-se necessário uma revisão bibliográfica. Entretanto, trabalhos desta natureza com linhagens homozigóticas não são comuns, já que o objetivo para o desenvolvimento de novos cultivares está no emprego do menor tempo possível, aliado ao mínimo gasto. Para atingir tal objetivo tem sido utilizada a seleção precoce.

Um indicativo do sucesso de um programa de melhoramento genético é a extensão pela qual seus produtos são descartados ou selecionados. Tanto na evolução como no melhoramento de plantas, as populações estão sendo constantemente, submetidas a crivos, pelos quais só passam os tipos superiores. Neste processo continuado de peneiramento, a força primordial é a seleção. Os principais métodos de 
seleção de linhagens em espécies autógamas dividem-se em dois grupos (1) seleção na fase de heterozigose e (2) seleção de linhagens homozigóticas (Allard, 1971).

Diferentes métodos de seleção foram propostos, em diversos trabalhos realizados, com o objetivo de melhorar o processo seletivo de linhagens superiores. Como exemplo, Cowen et al (1983) testaram cinco métodos diferentes de seleção em dez populações de aveia por três anos. Os resultados obtidos mostraram que a seleção truncada foi a mais eficiente para o aumento de produtividade; entretanto as linhagens tendiam a ser mais tardias e altas. Assim sendo, todos os métodos de seleção de linhagens superiores apresentam vantagens e desvantagens, tais como ampliação do custo programa ou o maior acúmulo de trabalho. Portanto, ainda não há o método ideal de seleção de linhagens superiores.

Os resultados da avaliação e seleção são determinados pelo tamanho e qualidade dos experimentos, assim como, pelas propriedades intrínsecas das linhagens. Em um experimento com baixo número de repetições e parcelas pequenas, eventualmente, uma linhagem muito boa e outra muito ruim podem não apresentar diferença significativa; provavelmente este problema não ocorra em um experimento com parcelas maiores e com maior número de repetições. É claro que, ocasionalmente, uma boa linhagem pode ser descartada e uma linhagem ruim pode ser selecionada devido aos erros experimentais que distorcem o verdadeiro ranqueamento das linhagens (Finney, 1958).

Com o objetivo de melhorar a eficiência de seleção, Finney (1958) propôs um esquema de seleção em várias etapas. O programa de melhoramento seria constituído inicialmente de $\mathrm{N}$ linhagens. Durante os $\mathrm{k}$ anos seguintes, estas seriam reduzidas para $\mathrm{n}$ linhagens. Desse modo, $\mathrm{n}=\pi \mathrm{N}$, onde $\pi$ é a intensidade total de seleção, determinada pelo melhorista; $\pi$ pode ser muito pequeno, mas nunca menor que $1 / \mathrm{N}$. A redução (seleção) seria realizada em $\mathrm{k}$ etapas, tendo por base os resultados dos experimentos. $\mathrm{O}$ processo proposto é feito de acordo com as etapas a seguir:

Etapa 1: No primeiro ano, todas as $\mathrm{N}$ linhagens são avaliadas; a porção $\mathrm{P}_{1}$ apresentando os melhores rendimentos é selecionada e o restante $\left(1-\mathrm{P}_{1}\right)$ é descartado. 
Etapa 2: No segundo ano, as $P_{1} N$ linhagens selecionadas são submetidas a uma nova avaliação experimental com um número maior de repetições; a porção $\mathrm{P}_{2}$ com os melhores rendimentos é selecionada e as demais são descartadas.

Este processo continua por $\mathrm{k}$ etapas, e de maneira geral tem-se:

Etapa $\mathrm{x}$ : No ano $\mathrm{x}$, as $\left(\mathrm{P}_{1} \mathrm{P}_{2} \ldots . \mathrm{P}_{\mathrm{x}-1}\right) \mathrm{N}$ linhagens remanescentes do ano $(\mathrm{x}-1)$ são submetidas a uma nova avaliação e a melhor porção $\mathrm{P}_{\mathrm{x}}$ é selecionada.

A fração de seleção $(\mathrm{P})$ ou porção selecionada anualmente é variável dependendo da fase do programa de melhoramento genético ou da qualidade dos experimentos. Nas fases iniciais, a intensidade de seleção deve ser menor e a seleção deve ser realizada para os caracteres de alta herdabilidade. Nesta fase, o número de linhagens é muito grande, é pequena a quantidade de semente de cada material e, consequentemente, a avaliação se dá em experimentos com poucas repetições e com parcelas pequenas, sendo menor a precisão experimental e menor a eficiência de seleção. Nas fases intermediárias e finais, a intensidade de seleção deve ser maior, pois nestas fases, a precisão experimental é melhor, devido o maior número de repetições e maior tamanho das parcelas e, repetição em vários locais. Portanto, a seleção anual da fração $\mathrm{P}$ pode ser variável, de modo que apenas $\mathrm{n}$ linhagens estejam ao final das $\mathrm{k}$ etapas de seleção, atendendo à intensidade de seleção $(\pi)$ proposta inicialmente. Portanto, a expressão fica assim:

$$
\mathrm{P}_{1} \mathrm{P}_{2} \mathrm{P}_{3} \ldots . . \mathrm{P}_{\mathrm{k}-1} \mathrm{P}_{\mathrm{k}}=\pi \text {, assim, }\left(\mathrm{P}_{1} \mathrm{P}_{2} \mathrm{P}_{3} \ldots . . \mathrm{P}_{\mathrm{k}-1} \mathrm{P}_{\mathrm{k}}\right) \mathrm{N}=\mathrm{n} \quad \text { ou } \pi \mathrm{N}=\mathrm{n}
$$

Com a aplicação do esquema de seleção, descrito acima, proposto por Finney (1958), ocorreu uma melhoria na eficiência de seleção. Entretanto, Wricke \& Weber (1986) afirmam que a resposta à seleção pode ser ainda mais eficiente, ou seja, as linhagens superiores podem ser melhor avaliadas e melhor selecionadas. Estes autores propõem a seleção Seqüencial, ou seja, a utilização das informações conjuntas da primeira etapa de seleção $\left(\mathrm{P}_{1}\right)$ na segunda etapa $\left(\mathrm{P}_{2}\right)$ e assim por diante nas seguintes etapas de avaliação e seleção. 
Van Sanford et al. (1993) realizaram um estudo para desenvolver um método para avaliar o peso do desempenho em locais primários, em relação aos ambientes em que se deseja recomendar o cultivar, baseado nas correlações entre esses locais. Avaliando diversos genótipos de soja nos Estados Unidos, em Kentucky, de 1987 a 1991, os autores desenvolveram um índice de seleção baseado nas correlações genéticas entre os desempenhos de cultivares em locais primários (Lexington e Princeton) e os ambientes visados. Em quatro dos cinco anos de estudo, um número menor de mudanças na ordenação dos genótipos ocorreu quando a classificação nos locais primários foi baseada no relacionamento entre o desempenho do cultivar nos locais primários e a média total de todos os locais. Correlações para produção entre Lexington e Princeton variaram de ano para ano indicando alterações ambientais, influenciando no desempenho dos genótipos.

Segundo Branch \& Hildebrand (1989), os programas de melhoramento, normalmente, selecionam indivíduos de populações em apenas um local. Esta restrição pode resultar no desenvolvimento de genótipos adaptados às condições ambientais prevalecentes num local em particular. Branch et al, (1991) propuseram um método de seleção Seqüencial para minimizar os efeitos da interação genótipos por ambientes no processo de seleção de linhagens. O método envolve a seleção cíclica em vários ambientes ao contrário da seleção praticada no mesmo local todo ano. O método genealógico, Single Seed Descent (SSD) e o Seqüencial foram testados e comparados em três anos de seleção e avaliação para produção de grãos e resistência a doenças foliares em amendoim. Os resultados demonstraram que o método de seleção Seqüencial foi significativamente superior para a seleção combinada dos caracteres propostos, pois reduziu os efeitos da interação genótipos $x$ ambientes, o que prejudicava o processo de seleção de genótipos superiores.

Guimarães (1985) realizou um trabalho com seleção recorrente em soja onde foram comparados diferentes ciclos de avaliação e seleção mesclados com diferentes ciclos de intercruzamento. A principal conclusão obtida foi que para aumentar a produtividade de grãos de em soja através da utilização da seleção recorrente, a melhor 
estratégia era realizar dois ciclos de avaliação e seleção de linhagens e um ciclo de intercruzamento entre os indivíduos selecionados. Isso mosta a melhor eficiência na seleção das linhagens superiores para a utilização em um programa de cruzamentos, quando esta foi realizada através da avaliação das linhagens em dois anos, quando comparada à seleção das linhagens avaliadas em um único ano.

Para a utilização da estratégia de seleção baseada na avaliação em vários anos é necessário que o genótipo das linhagens sejam reproduzidos integralmente de um ano para outro, caso contrário, as médias obtidas em um ano não seriam correspondentes às obtidas no ano seguinte. Isto acontece com espécies que se reproduzem vegetativamente ou espécies autógamas já homozigóticas, que podem ser multiplicadas com precisão, permitindo a avaliação destas em experimentos com repetições, em vários locais e anos. Portanto, livre dos efeitos da interação genótipos $\mathrm{x}$ ambientes, o valor médio de cada linhagem pode ser obtido com alta precisão, o que permite a identificação e seleção do genótipo superior.

Souza Jr. (1995) relata que a seleção baseada na avaliação em vários anos deve ser efetiva apenas para caracteres de baixa herdabilidade, onde a variância ambiental é muito superior à variância genética e, para os caracteres de alta herdabilidade, onde a variância ambiental é inferior ou igual à variância genética, a eficiência deste tipo de seleção seria reduzida. Entretanto, como a seleção em várias etapas pode ser utilizada a partir da segunda geração de avaliação, pois tem um efeito cumulativo, pode gerar no final uma eficiência acumulada elevada mesmo com valores relativamente baixos em cada etapa.

Para comprovar a eficiência superior do método da seleção baseada na avaliação de vários anos, Souza Jr. (1995) fez uma simulação teórica das eficiências relativas para um processo seletivo com seis etapas, com número de repetições variando de 2 a 12, respectivamente, e dois valores de herdabilidades $(0,14$ e 0,67$)$ representando diferentes caracteres. Os resultados mostraram a elevada eficiência de seleção para caracteres de baixa herdabilidade, como era de se esperar. O efeito cumulativo foi muito expressivo, atingindo $97,6 \%$ na última etapa, indicando que a eficiência do uso 
constante da seleção em várias etapas é quase o dobro daquela baseada nas informações de cada etapa em separado. Para o caráter de alta herdabilidade a eficiência acumulada do método atingiu apenas $9,3 \%$ após seis etapas de seleção, indicando um valor muito pequeno para se considerar o seu uso para estes tipos de caracteres.

Se os recursos para a experimentação não fossem limitados, poder-seia negligenciar os erros no processo de seleção pelo suficiente aumento no tamanho das parcelas dos experimentos e/ou aumento do número de repetições. Enuretanto, a equipe técnica, os recursos financeiros, a área de experimentação, ou a combinação destes fatores, impõem uma severa restrição à quantidade de materiais testados anualmente (Finney, 1958). Portanto, há a necessidade de implantação de estratégias de avaliação e seleção mais eficazes nos programas de melhoramento genético.

Fazendo uma abordagem sobre os custos envolvidos na formação do ganho genético através da seleção em várias etapas, Namkoong (1970) relata que qualquer função de custo poderia ser utilizada. Entretanto, deve ser uma função simples que apresente uma relação linear entre os custos e o número de linhagens selecionadas. Portanto, o custo total ficaria formulado assim:

Custo $=\mathrm{NC}_{1}+\mathrm{P}_{1} \mathrm{NC}_{2}+\left(\mathrm{P}_{1} \mathrm{P}_{2}\right) \mathrm{NC}_{3}+\ldots .+\left(\mathrm{P}_{1} \mathrm{P}_{2} \mathrm{P}_{3} \ldots \mathrm{P}_{\mathrm{k}-1}\right) \mathrm{NC}_{\mathrm{k}}$

onde,

$\mathrm{N}$ : Número inical de linhagens,

$\mathrm{C}_{1}, \mathrm{C}_{2}, \mathrm{C}_{3}$ e $\mathrm{C}_{\mathrm{k}}$ : Custo unitário das etapas 1, 2, 3 e k, respectivamente, $\mathrm{P}_{1}, \mathrm{P}_{2}, \mathrm{P}_{3}$ e $\mathrm{P}_{\mathrm{k}-1}$ : Intensidade de seleção nas etapas 1, 2, 3 e k-1, respectivamente.

Assim sendo, quanto mais eficiente for o método de avaliação e seleção de linhagens, maior será a intensidade de seleção aplicada em cada etapa (P) e menor tempo será gasto para a obtenção do genótipo superior. Consequentemente, os custos totais envolvidos no programa de melhoramento genético serão menores. Portanto, numa economia globalizada, onde o sojicultor brasileiro tem de competir de igual para igual com os maiores e melhores produtores mundiais, há a necessidade de, cada vez mais, tornar os programas de melhoramento genético mais eficientes, através 
do aumento do número de linhagens testadas anualmente, redução dos custos totais e melhoria da estratégia de avaliação e seleção. 


\section{MATERIAL E MÉTODOS}

\subsection{Material genético}

Em janeiro de 1987, foram realizados cruzamentos dialélicos com oito genitores da coleção de soja mantida pelo Setor de Genética Aplicada às Espécies Autógamas do Departamento de Genética da Escola Superior de Agricultura "Luiz de Queiroz", da Universidade de São Paulo, os quais foram selecionados, quanto aos caracteres de alta produção de grãos e alto teor de proteína, principalmente.

Quatro cruzamentos foram escolhidos para a realização deste trabalho, em função da quantidade de linhagens disponíveis. O método de condução das sementes oriundas dos cruzamentos à homozigose foi o SSD (Single Seed Descent). No ano agrícola de 1992/93, foram colhidas plantas individuais na geração $F_{8}\left(F_{7: 8}\right)$ que deram origem às linhagens homozigóticas que compreendem o material utilizado neste trabalho. Os cruzamentos selecionados foram os seguintes:

1: OC-79230 X BR80-8858

2: $\mathrm{BR} 80-8858 \quad \mathrm{X} \quad \mathrm{BR} 80-14853$

3: BR80-14853 X PI-165896

4: BR80-14853 X PI-239235

A descrição dos genótipos utilizados nos cruzamentos escolhidos (Pimentel, 1991), encontra-se a seguir: 
A - OC-79230: Linhagem brasileira, proveniente da OCEPAR, com ciclo aproximado de 60 dias para o florescimento, hábito de crescimento determinado, flor branca, semente amarela, pubescência cinza e hilo marrom.

B - BR80-8858: Linhagem brasileira, proveniente do Centro Nacional de Pesquisa de Soja (CNPSo) da EMBRAPA, com ciclo aproximado de 53 dias para florescimento, hábito de crescimento indeterminado, flor roxa, semente amarela, pubescência e hilo cinza.

C - BR80-14853: Linhagem brasileira proveniente da EMBRAPA/CNPSo, com ciclo aproximado para florescimento de 51 dias, hábito de crescimento indeterminado, flor roxa, semente verde, pubescência marrom e hilo preto.

D - PI-165896: Linhagem norte-americana fornecida pela EMBRAPA/CNPSo, com ciclo aproximado de 47 dias para florescimento, hábito de crescimento determinado, flor roxa, semente preta, pubescência marrom e hilo preto.

E - PI-239235: Linhagem norte-americana fornecida pela EMBRAPA/CNPSo, com ciclo de 55 dias para florescimento, hábito de crescimento indeterminado, flor branca, semente amarela, pubescência e hilo cinza.

\subsection{Caracterização do ambiente}

Os estudos foram realizados, em solo do tipo terra roxa estruturada série "Luiz de Queiroz" (Ranzani et al., 1966), na área experimental do Departamento de Genética da Escola Superior de Agricultura "Luiz de Queiroz", no município de Piracicaba, SP, situada a $22^{\circ} 42^{\prime} 30^{\prime \prime}$ de latitude sul, $47^{\circ} 38^{\prime} 00^{\prime \prime}$ de latitude oeste e a $537 \mathrm{~m}$ de altitude em relação ao nível do mar.

De acordo com a classificação climática de THORNTHWAITE para esta região, a fórmula climática resulta em $\mathrm{C} 2 \mathrm{rA}^{\prime} \mathrm{a}^{\prime}$, ou seja, clima úmido com pequeno déficit de água, megatérmico, e com vegetação o ano todo. 


\subsection{Execução experimental}

\subsubsection{Delineamento e características dos experimentos}

Para a realização deste trabalho, foi obtido o maior número de linhagens possível de cada um dos quatro cruzamentos selecionados. Portanto, havia um número de plantas diferentes, que deram origem a um número diferente de linhagens por cruzamento.

Os experimentos de avaliação das linhagens foram instalados no campo experimental nos anos de 1993/94, 1994/95 e 1995/96. Como o número de linhagens dentro de cada cruzamento era grande, as linhagens do mesmo cruzamento foram divididas em conjuntos. Cada um deles foi constituído por 20 linhagens, os dois genitores do cruzamento em questão e cinco testemunhas, que foram: IAC-12, IACFoscarin-31, Biloxi, BR80-14887, IAC-5 e IAC-8..

Para as avaliações destes experimentos nos três anos já citados, foi utilizado um delineamento em blocos ao acaso, onde o número de repetições foi igual a três. A parcela foi constituída de uma fileira de $1 \mathrm{~m}$ de comprimento com um espaçamento de $0,50 \mathrm{me} 17$ plantas dentro da fileira no estande ideal.

Com base nas avaliações realizadas nos três anos de experimentação, foram testados dois métodos de seleção das linhagens homozigóticas dentro de cada conjunto e cruzamento. No ano de 1997/98, foi instalado um experimento para avaliação das linhagens selecionadas e não selecionadas dentro de cada método de seleção. O delineamento experimental utilizado foi o de blocos casualizados, com seis repetições. A parcela foi constituída de uma fileira de $2 \mathrm{~m}$ de comprimento com um espaçamento de $0,50 \mathrm{~m}$ e 17 plantas $/ \mathrm{m}$ no estande ideal.

O manejo da cultura, como o preparo do solo, a adubação, o controle de plantas daninhas e insetos mastigadores e sugadores foi executado de acordo com as práticas recomendadas pelos órgãos oficiais. 
No momento das semeaduras, que foram realizadas manualmente, foi feito a inoculação das sementes com uma estirpe de Bradyrhizobium japonicum, pulverizando-se no sulco de plantio uma solução do inoculante na forma líquida após a semeadura, seguida da cobertura dos sulcos.

Durante os primeiros dias após a semeadura, dependendo da necessidade, foi realizada a prática da irrigação, através de aspersores suspensos, no sentido de evitar falhas na germinação.

\subsubsection{Caracteres avaliados}

As observações foram realizadas nas diferentes linhagens homozigóticas dos quatro cruzamentos. Os caracteres avaliados foram o número de dias para o florescimento, altura das plantas no florescimento, número de dias para a maturação, altura das plantas na maturação, acamamento e produção de grãos.

Para a execução deste trabalho, foram utilizadas apenas as informações de dois caracteres, um de alta e outro de baixa herdabilidade, isto é, altura de plantas na maturação e produção de grãos, respectivamente. Em ambos, o objetivo foi a seleção para aumentar o caráter, embora não seja necessariamente agronomicamente correta a elevação da altura de plantas. Entretanto, isto foi feito para testar a metodologia. Portanto, os caracteres utilizados neste trabalho foram assim avaliados:

- AM: altura média das plantas da parcela em centímetros, na maturação. Distância compreendida entre a base e o ápice da haste principal na época da maturação. Foram medidas cinco plantas por parcela. Para a realização das análises estatísticas foi utilizada a média das alturas das cinco plantas.

- PG: produção de grãos. Avaliada na maturação através do peso de grãos (g) de cada parcela. 


\subsubsection{Métodos de seleção}

Foram comparados dois métodos de seleção: um baseado nas informações oriundas de apenas um ano de cultivo denominado de Independente e outro baseado no acúmulo de informações ao longo dos anos de avaliações, chamado de Seqüencial.

O método de seleção baseado nas informações obtidas em apenas um ano de experimentação (Independente), consistiu em selecionar $70 \%$ da linhagens superiores no primeiro ano, $50 \%$ das linhagens superiores no segundo ano e $42,9 \%$ das linhagens superiores no terceiro ano, perfazendo uma intensidade de seleção total de $15 \%$. Ou seja, de cada conjunto constituído inicialmente de 20 linhagens, foram selecionadas as 14 linhagens superiores baseadas no primeiro ano (1993/94), das quais, foram selecionadas as sete linhagens superiores com as informações do segundo ano (1994/95) e com as informações do terceiro ano (1995/96), foram selecionadas as três linhagens superiores. No ano 1997/98, foram avaliadas todas as 20 linhagens, comparando-se as três linhagens selecionadas dos conjuntos por este método com as 20 linhagens iniciais, obtendo assim, o ganho observado com seleção.

O segundo método de seleção (Seqüencial) tem como princípio, o aproveitamento das informações obtidas ao longo dos anos de experimentação, de acordo com o método proposto por Wricke \& Weber (1986) e Souza Jr. (1995). Ou seja, inicialmente foram selecionadas $70 \%$ das linhagens superiores com base no primeiro ano de avaliação, de maneira idêntica ao método anterior. Com base nas médias dos dois primeiros anos (1993/94 e 1994/95), no segundo ano foi aplicada uma intensidade de seleção da ordem de $50 \%$, e no terceiro ano foram selecionadas $42,9 \%$ das linhagens superiores com base nas médias dos três anos de avaliação, que, igualmente ao método anterior, perfaz uma intensidade de seleção final de 15\%. Portanto, das 20 linhagens dentro de cada conjunto por cruzamento, foram selecionadas as 14 linhagens superiores baseadas na avaliação do primeiro ano. Com as informações acumuladas destas 14 linhagens nos dois anos de experimentação foram selecionadas as sete linhagens 
superiores que foram avaliadas no ano seguinte (1995/96) para a seleção das três superiores, baseadas no acúmulo de informações dos três anos de avaliações. Estas três linhagens selecionadas por conjunto foram testadas no ano 1997/98, com as 17 linhagens não selecionadas por este método, e assim, foi obtido o ganho observado com seleção.

\subsubsection{Análises de variância}

Inicialmente, foi realizada uma análise de variância em blocos ao acaso para cada conjunto dentro de cada cruzamento, para cada um dos três primeiros anos de experimentação, individualmente. Posteriormente, os diferentes conjuntos de cada cruzamento foram reunidos em uma única análise agrupada. Também foram feitas as análises conjuntas dos três anos.

As análises foram efetuadas com o total de parcelas para o caráter produção de grãos e com médias de parcelas para a altura das plantas na maturação.

As análises de variância individuais foram realizadas de acordo com o delineamento experimental de blocos ao acaso e com o seguinte modelo:

$\mathrm{Y}_{\mathrm{ij}}=\mu+\mathrm{t}_{\mathrm{i}}+\mathrm{r}_{\mathrm{j}}+\mathrm{e}_{\mathrm{ij}}$,

onde:

$Y_{i j}$ é a observação referente à linhagem "i" na repetição "j";

$\mu$ é a média geral;

$t_{i} \quad$ é o efeito aleatório de tratamentos (linhagens); $\mathrm{i}=1,2,3, \ldots \mathrm{L}$;

$r_{j}$ é o efeito aleatório de repetições; $\mathrm{j}=1,2,3, \ldots \mathrm{R}$;

$e_{i j}$ é o erro experimental associado à parcela $\mathrm{ij}$. 
Segundo este modelo, o esquema da análise de variância encontra-se na Tabela 1.

Tabela 1: Esquema da análise de variância individual.

\begin{tabular}{lcccl}
\hline FV & GL & QM & F & E(QM) \\
\hline REPETIÇÕES & $\mathrm{R}-1$ & $\mathrm{Q}_{3}$ & $\mathrm{Q}_{3} / \mathrm{Q}_{1}$ & $\sigma^{2}+\mathrm{T} \sigma_{\mathrm{R}}^{2}$ \\
LINHAGENS & $\mathrm{L}-1$ & $\mathrm{Q}_{2}$ & $\mathrm{Q}_{2} / \mathrm{Q}_{1}$ & $\sigma^{2}+\mathrm{R} \sigma_{\mathrm{L}}^{2}$ \\
RESÍDUO & $(\mathrm{R}-1)(\mathrm{L}-1)$ & $\mathrm{Q}_{1}$ & & $\sigma^{2}$ \\
\hline
\end{tabular}

Em seguida, as análises de variância individuais foram agrupadas, reunindo-se os conjuntos estudados. Assim, para cada cruzamento foi realizada uma análise agrupada. O teste de homocedasticidade dos quadrados médios, proposto por Gomes (1990), foi aplicado, indicando, portanto, que havia a possibilidade de realização das análises agrupadas. As análises agrupadas dos diferentes conjuntos de cada cruzamento seguiram um esquema hierárquico, baseado no seguinte modelo matemático:

$$
Y_{i j k}=\mu+t_{i(k)}+r_{j(k)}+c_{k}+e_{(i j) k},
$$

onde:

$Y_{i j k}$ é a média do tratamento "i" da repetição "j" no conjunto "k";

$c_{k}$ é o efeito de conjuntos; $\mathrm{k}=1,2,3, \ldots \mathrm{C}$.

Os demais parâmetros do modelo têm o mesmo significado do esquema anterior, sendo todos hierárquicos em relação ao efeito de conjuntos $c_{k}$. $O$ esquema da análise de variância agrupada encontra-se na Tabela 2. 
Tabela 2: Esquema da análise de variância agrupada por conjuntos.

\begin{tabular}{lcccc}
\hline FV & $\mathrm{GL}$ & $\mathrm{QM}$ & $\mathrm{F}$ & $\mathrm{E}(\mathrm{QM})$ \\
\hline REPETIÇÕES/CONJUNTOS & $\mathrm{C}(\mathrm{R}-1)$ & $\mathrm{Q}_{3}$ & $\mathrm{Q}_{3} / \mathrm{Q}_{1}$ & $\sigma^{2}+\mathrm{L}_{\mathrm{R}}^{2}$ \\
LINHAGENS/CONJUNTOS & $\mathrm{C}(\mathrm{L}-1)$ & $\mathrm{Q}_{2}$ & $\mathrm{Q}_{2} / \mathrm{Q}_{1}$ & $\sigma^{2}+\mathrm{R}_{\mathrm{L}}^{2}$ \\
RESÍDUO MÉDIO & $\mathrm{C}(\mathrm{R}-1)(\mathrm{L}-1)$ & $\mathrm{Q}_{1}$ & & $\sigma^{2}$ \\
\hline
\end{tabular}

As análises de variância conjuntas dos três primeiros anos foram realizadas de acordo com o seguinte modelo para cada conjunto:

$Y_{i j l}=\mu+t_{i}+r_{j(1)}+a_{1}+(t a)_{i l}+e_{i j(l)}$

onde:

$\mathrm{a}_{1} \quad$ é $\mathrm{o}$ efeito aleatório de anos; $1=1,2, \ldots \mathrm{A}$;

$(\text { ta })_{\text {il }}$ é o efeito aleatório da interação de linhagens com anos;

Os demais parâmetros têm o mesmo significado do esquema anterior. O esquema da análise de variância está apresentado na Tabela 3.

Tabela 3: Esquema da análise de variância conjunta dos três primeiros anos para cada conjunto.

\begin{tabular}{lcccc}
\hline FV & $\mathrm{GL}$ & $\mathrm{QM}$ & $\mathrm{F}$ & $\mathrm{E}(\mathrm{QM})$ \\
\hline ANOS & $\mathrm{A}-1$ & $\mathrm{Q}_{4}$ & $\mathrm{Q}_{3} / \mathrm{Q}_{2}$ & $\sigma^{2}+\mathrm{R} \sigma_{\mathrm{LxA}}^{2}+\mathrm{RL} \sigma_{\mathrm{A}}^{2}$ \\
LINHAGENS & $\mathrm{L}-1$ & $\mathrm{Q}_{3}$ & $\mathrm{Q}_{4} / \mathrm{Q}_{2}$ & $\sigma^{2}+\mathrm{R} \sigma_{\mathrm{LxA}}^{2}+\mathrm{RA} \sigma_{\mathrm{L}}^{2}$ \\
LINHAGENS x ANOS & $(\mathrm{A}-\mathrm{l})(\mathrm{L}-1)$ & $\mathrm{Q}_{2}$ & $\mathrm{Q}_{2} / \mathrm{Q}_{1}$ & $\sigma^{2}+\mathrm{R} \sigma_{\mathrm{LxA}}^{2}$ \\
RESÍDUO MÉDIO & $\mathrm{A}(\mathrm{R}-1)(\mathrm{L}-1)$ & $\mathrm{Q}_{1}$ & & $\sigma^{2}$ \\
\hline
\end{tabular}

As análises de variância conjuntas e agrupadas para conjuntos dos três primeiros anos foram realizadas de acordo com o seguinte modelo: 
$\mathrm{Y}_{\mathrm{ijkl}}=\mu+\mathrm{t}_{\mathrm{i}(\mathrm{k})}+\mathrm{r}_{\mathrm{j}(\mathrm{kl})}+\mathrm{a}_{\mathrm{l}(\mathrm{k})}+\mathrm{c}_{\mathrm{k}}+(\mathrm{ta})_{\mathrm{il}(\mathrm{k})}+\mathrm{e}_{\mathrm{ij}(\mathrm{kl})}$

Os demais parâmetros têm o mesmo significado do esquema anterior, sendo todos hierárquicos em relação ao efeito de conjuntos $\left(c_{k}\right)$. O esquema da análise de variância está na Tabela 4.

Tabela 4: Esquema da análise de variância conjunta agrupada dos três primeiros anos.

\begin{tabular}{lcccc}
\hline FV & $\mathrm{GL}$ & $\mathrm{QM}$ & $\mathrm{F}$ & $\mathrm{E}(\mathrm{QM})$ \\
\hline ANOS / CONJUNTO & $\mathrm{C}(\mathrm{A}-1)$ & $\mathrm{Q}_{4}$ & $\mathrm{Q}_{4} / \mathrm{Q}_{2}$ & $\sigma^{2}+\mathrm{R} \sigma_{\mathrm{LxA}}^{2}+\mathrm{RL} \sigma_{\mathrm{A}}^{2}$ \\
LINHAGENS / CONJ & $\mathrm{C}(\mathrm{L}-1)$ & $\mathrm{Q}_{3}$ & $\mathrm{Q}_{3} / \mathrm{Q}_{2}$ & $\sigma^{2}+\mathrm{R} \sigma_{\mathrm{LxA}}^{2}+\mathrm{RA} \sigma_{\mathrm{L}}^{2}$ \\
(LINHAGENS x ANOS)/CONJ & $\mathrm{C}(\mathrm{A}-1)(\mathrm{L}-1)$ & $\mathrm{Q}_{2}$ & $\mathrm{Q}_{2} / \mathrm{Q}_{1}$ & $\sigma^{2}+\mathrm{R} \sigma_{\mathrm{LxA}}^{2}$ \\
RESÍDUO MÉDIO & $\mathrm{AC}(\mathrm{R}-1)(\mathrm{L}-1)$ & $\mathrm{Q}_{1}$ & & $\sigma^{2}$ \\
\hline
\end{tabular}

É importante ressaltar que o número de linhagens variou entre os cruzamentos, variando portanto, o número de conjuntos por cruzamento, conforme descrito a seguir:

\begin{tabular}{lcc}
\hline Cruzamentos & № de conjuntos & № de linhagens \\
\hline 1 - OC-79230 X BR-80-8858 & 4 & 80 \\
2- BR-80-8858 X BR-80-14853 & 5 & 100 \\
3 - BR-80-14853 X PI-165896 & 4 & 78 \\
4 - BR-80-14853 X PI-239235 & 5 & 97 \\
\hline
\end{tabular}




\subsubsection{Estimativas dos componentes de variância e dos parâmetros derivados}

Com base nas análises de variância agrupadas em cada ano, provenientes da Tabela 2, foram estimados os seguintes parâmetros:

- Variância genética entre linhagens:

$$
\hat{\sigma}_{\mathrm{L}}^{2}=\frac{\mathrm{Q}_{2}-\mathrm{Q}_{1}}{\mathrm{R}}=\sigma_{\mathrm{A}}^{2}
$$

- Variância do erro experimental entre parcelas:

$$
\hat{\sigma}^{2}=Q_{1}
$$

- Herdabilidade entre médias de parcelas :

$$
\hat{\mathrm{h}}_{\mathrm{x}}^{2}=\frac{\sigma_{\mathrm{L}}^{2}}{\sigma_{\mathrm{L}}^{2}+\frac{\sigma^{2}}{\mathrm{R}}}=\frac{\mathrm{Q}_{2}}{\mathrm{R}}
$$

- Coeficiente de variação experimental:

$$
C V_{e}=\left(\frac{\sqrt{\sigma^{2}}}{\bar{x}}\right) 100
$$

- Coeficiente de variação genético:

$$
\mathrm{CV}_{\mathrm{g}}=\left(\frac{\sqrt{\sigma_{\mathrm{L}}^{2}}}{\overline{\mathrm{x}}}\right) 100
$$

Com base nas análises de variância conjuntas provenientes da Tabela 4, foram estimados os seguintes parâmetros:

- Variância genética entre linhagens:

$$
\hat{\sigma}_{\mathrm{L}}^{2}=\frac{\mathrm{Q}_{3}-\mathrm{Q}_{2}}{\mathrm{RA}}=\sigma_{\mathrm{A}}^{2}
$$

- Variância genética da interação entre linhagens e anos:

$$
\hat{\sigma}_{\mathrm{LXA}}^{2}=\frac{\mathrm{Q}_{2}-\mathrm{Q}_{1}}{\mathrm{R}}
$$


- Variância do erro experimental:

$$
\hat{\sigma}^{2}=Q_{1}
$$

- Herdabilidade entre médias de parcelas

$$
\hat{\mathrm{h}}_{\mathrm{x}}^{2}=\frac{\sigma_{\mathrm{L}}^{2}}{\sigma_{\mathrm{L}}^{2}+\frac{\sigma_{\mathrm{LXA}}^{2}}{\mathrm{~A}}+\frac{\sigma^{2}}{\mathrm{RA}}}=\frac{\mathrm{Q}_{3}}{\mathrm{RA}}
$$

- Coeficiente de variação genético:

$$
\mathrm{CV}_{\mathrm{g}}=\left(\frac{\sqrt{\sigma_{\mathrm{L}}^{2}}}{\overline{\mathrm{x}}}\right) 100
$$

3.3.6 Intervalos de confiança associados às estimativas dos parâmetros

Os intervalos de confiança associados às estimativas das variâncias genéticas entre linhagens, variâncias das interações de linhagens com anos, variâncias do erro experimental e dos coeficientes de herdabilidade foram calculadas de acordo com as expressões apresentadas por Barbin (1993).

- Intervalo de confiança (IC) associado à estimativa da variância do erro experimental $\left(\sigma^{2}\right)$ :

$$
\mathrm{IC}=\mathrm{P}\left[\frac{\mathrm{f} \sigma^{2}}{\chi_{\mathrm{f} ; 0,975}^{2}} \leq \sigma^{2} \leq \frac{\mathrm{f} \sigma^{2}}{\chi_{\mathrm{f} ; 0,025}^{2}}\right]=0,95,
$$

em que:

$\sigma^{2}$ : variância do erro experimental,

$\chi^{2}$ : qui-quadrado tabelado,

$f$ : número de graus de liberdade do erro experimental. 
- Intervalo de confiança (IC) associado à estimativa da variância genética de linhagens $\left(\sigma_{L}^{2}\right)$ :

$$
\mathrm{IC}=\mathrm{P}\left[\frac{n t \sigma_{L}^{2}}{\chi_{n t ; 0,975}^{2}} \leq \sigma_{L}^{2} \leq \frac{n t \sigma_{L}^{2}}{\chi_{n t ; 0,025}^{2}}\right]=0,95,
$$

em que:

$\sigma_{L}^{2}$ : variância genética de linhagens,

$\chi^{2}$ : qui-quadrado tabelado e

$n t$ : número de graus de liberdade associados à estimativa da variância genética de linhagens $\left(\sigma_{L}^{2}\right)$.

O valor $n t$ foi obtido através do método de Satterthwaite, que é uma fórmula empregada para calcular o número de graus de liberdade associados a uma estimativa de variância obtida da combinação linear de dois quadrados médios, referentes a duas fontes de variação, com números de graus de liberdade conhecidos (Barbin, 1993):

$$
n t=\frac{\left(Q M_{L}-Q M_{L x A}\right)^{2}}{\frac{Q M_{L}^{2}}{f_{1}}+\frac{Q M_{L \times A}^{2}}{f_{2}}}
$$

em que:

$\mathrm{QM}_{\mathrm{L}}$ : quadrado médio das linhagens,

$\mathrm{QM}_{\mathrm{LxA}}$ : quadrado médio das interações das linhagens com anos,

$f_{l}$ : número de graus de liberdade de linhagens,

$f_{2}$ : número de graus de liberdade da interação de linhagens com anos.

- Intervalo de confiança (IC) associado à estimativa da variância da interação de linhagens com anos $\left(\sigma_{L x A}^{2}\right)$ :

$$
\mathrm{IC}=\mathrm{P}\left[\frac{\mathrm{nt} \sigma_{\mathrm{LxA}}^{2}}{\chi_{\mathrm{nt} ; 0,975}^{2}} \leq \sigma_{\mathrm{LxA}}^{2} \leq \frac{\mathrm{nt} \sigma_{\mathrm{LxA}}^{2}}{\chi_{\mathrm{nt} ; 0,025}^{2}}\right]=0,95,
$$

em que: 
$\sigma_{L x A}^{2}$ : variância da interação de linhagens com anos,

$\chi^{2}$ : qui-quadrado tabelado e

$n t$ : número de graus de liberdade associados à estimativa da variância da interação de linhagens com anos $\left(\sigma_{L x A}^{2}\right)$, isto é, de acordo com Barbin (1993):

$$
n t=\frac{\left(Q M_{L x A}-Q M E\right)^{2}}{\frac{Q M_{L x A}^{2}}{f_{1}}+\frac{Q M_{E}^{2}}{f_{2}}}
$$

em que:

$\mathrm{QM}_{\mathrm{LxA}}$ : quadrado médio das interações das linhagens com anos,

$\mathrm{QM}_{\mathrm{E}}$ : quadrado médio do erro experimental,

$f_{l}$ : número de graus de liberdade das interações das linhagens com anos e

$f_{2}:$ número de graus de liberdade do erro experimental.

- Intervalo de confiança (IC) associado ao coeficiente de herdabilidade $\left(h_{\bar{x}}^{2}\right)$ por ano:

$$
\mathrm{IC}=\mathrm{P}\left\{\left\{1-\left[\left(\frac{\mathrm{Q}_{2}}{\mathrm{Q}_{1}}\right) \cdot \mathrm{F}_{0,975: f_{2}, f_{1}}\right]^{-1}\right\} \leq \mathrm{h}_{\overline{\mathrm{x}}}^{2} \leq\left\{1-\left[\left(\frac{\mathrm{Q}_{2}}{\mathrm{Q}_{1}}\right) \cdot \mathrm{F}_{0,025: f_{2}, f_{l}}\right]^{-1}\right\}\right\}=0,95,
$$

em que:

$\mathbf{h}_{\overline{\mathbf{x}}}^{2}$ : estimativa do coeficiente de herdabilidade,

$\mathrm{Q}_{1}$ : quadrado médio do erro experimental,

$\mathrm{Q}_{2}$ : quadrado médio do efeito de linhagens,

$\mathrm{F}_{0,975}$ : valor da distribuição de $\mathrm{F}$ para a probabilidade de $97,5 \%$,

$\mathrm{F}_{0,025}$ : valor da distribuição de $\mathrm{F}$ para a probabilidade de 2,5\%,

$f_{1}$ : número de graus de liberdade do erro experimental e

$f_{2}$ : número de graus de liberdade associado a linhagens. 
- Intervalo de confiança (IC) associado ao coeficiente de herdabilidade ( $\left.h_{x}^{2}\right)$ na análise conjunta:

$$
\mathrm{IC}=\mathrm{P}\left\{\left\{1-\left[\left(\frac{\mathrm{Q}_{3}}{\mathrm{Q}_{2}}\right) \mathrm{F}_{0,975: f 3, f 2}\right]^{-1}\right\} \leq \mathrm{h}_{\mathrm{x}}^{2} \leq\left\{1-\left[\left(\frac{\mathrm{Q}_{3}}{\mathrm{Q}_{2}}\right) \mathrm{F}_{0,025: f 3, f 2}\right]^{-1}\right\}\right\}=0,95,
$$

em que:

$\mathrm{Q}_{3}$ : quadrado médio do efeito de linhagens,

$\mathrm{Q}_{2}$ : quadrado médio da interação entre linhagens e anos,

$f_{3}$ : número de graus de liberdade associado a linhagens e

$f_{2}$ : número de graus de liberdade da interação de linhagens com anos.

\subsubsection{Resposta observada com seleção}

A resposta observada com seleção foi calculada, para os dois métodos de seleção (Seqüencial e Independente), para ambos os caracteres, através dos ganhos com seleção, que representa em última análise, o quanto a população melhorada foi superior à população original.

$\mathrm{Gs}=\overline{\mathrm{X}}_{\mathrm{M}}-\overline{\mathrm{X}}_{\mathrm{O}}$

Gs: ganho com seleção,

$\overline{\mathrm{X}}_{\mathrm{M}}$ : é a média das linhagens selecionadas,

$\overline{\mathrm{X}}_{\mathrm{O}}$ : é a média das linhagens iniciais ou da população original.

A eficiência de seleção $(\mathrm{EF})$ do método Seqüencial sobre o método Independente, foi calculada em valor absoluto:

$$
\mathrm{EF}=\overline{\mathrm{X}}_{1}-\overline{\mathrm{X}}_{2} \text {, onde: }
$$

$\overline{\mathrm{X}}_{1}$ : é a média das linhagens selecionadas baseadas no método Seqüencial,

$\overline{\mathrm{X}}_{2}$ : é a média das linhagens selecionadas baseadas no método Independente. 
Foi calculada, também, a eficiência de seleção do método Seqüencial sobre a seleção do método Independente em porcentagem relativa, de duas maneiras: (1) eficiência relativa de seleção baseada na média da população original e, (2) eficiência relativa de seleção baseada no ganho com o método de seleção Independente.

1. $E F(\%)=\left(\frac{\bar{X}_{1}-\bar{X}_{2}}{\bar{X}_{0}}\right) 100 \mathrm{e}$,

2. $\mathrm{EF}(\%)=\left(\frac{\mathrm{Gs}_{1}-\mathrm{Gs}_{2}}{\mathrm{Gs}_{2}}\right) 100$, onde:

$\mathrm{Gs}_{1}$ : é o ganho com seleção obtido pelo método Seqüencial,

$\mathrm{Gs}_{2}$ : é o ganho com seleção obtido pelo método Independente. 


\section{RESULTADOS E DISCUSSÃO}

\subsection{Análise Geral dos Dados}

Os resultados do presente trabalho foram obtidos a partir da avaliação de quatro populações homozigóticas de soja, em delineamentos de blocos ao acaso nos anos agrícolas de 1993/94, 1994/95, 1995/96 e 1997/98. Os experimentos foram instalados em um único ambiente, na área experimental do Departamento de Genética da Escola Superior de Agricultura "Luiz de Queiroz" da Universidade de São Paulo. No ano agrícola de 1996/97 o experimento foi perdido devido a problemas na aplicação de herbicidas, comprometendo a avaliação das linhagens.

$\mathrm{Na}$ Tabela 5 são apresentados os valores referentes às médias populacionais para os caracteres produção de grãos e altura das plantas na maturação oriundas dos cruzamentos (1) OC-79230 X BR80-8858, (2) BR80-8858 X BR80-14853, (3) BR80-14853 X PI-165896 e (4) BR80-14853 X PI-239235, em cada um dos quatro anos de avaliação, a média geral das linhagens em cada ano, bem como, a média de cada cruzamento nos três primeiros anos de avaliação, obtidas da análise conjunta de anos.

Para o caráter produção de grãos, as médias encontradas na avaliação do primeiro ano de experimentação, nos quatro cruzamentos, variaram de 178,93 a $255,99 \mathrm{~g} /$ parcela nos cruzamentos 3 e 2, respectivamente; de 135,47 a 152,26 g/parcela nos cruzamentos 3 e 4, respectivamente; na avaliação do segundo ano e, na avaliação do terceiro ano variaram de 144,26 a 250,09 g/parcela nos cruzamentos 3 e 2, respectivamente. Nestes três anos de avaliação e seleção, a parcela experimental foi constituída por uma linha de plantio de $1 \mathrm{~m}$ de comprimento e três repetições. 
No quarto ano de experimentação (1997/98), as médias variaram de 215,33 a 387,53 g/parcela nos cruzamentos 3 e 2, respectivamente. Neste ano, a parcela experimental foi uma linha de $2 \mathrm{~m}$ de comprimento e seis repetições, não sendo possível comparar estas médias com os valores obtidos nos anos anteriores devido ao diferente tamanho da parcela. Entretanto, baseado no desempenho médio dos cruzamentos nos anos de avaliação foi possível ordená-los, sendo os cruzamentos 1 e 2 os mais produtivos.

Para o caráter altura das plantas na maturação, na avaliação do primeiro ano, as médias encontradas nos quatro cruzamentos variaram de 71,56 a $87,91 \mathrm{~cm}$ nos cruzamentos 1 e 4, respectivamente; na avaliação do segundo ano variaram de $57,20 \mathrm{~cm}$ no cruzamento 1 a $69,41 \mathrm{~cm}$ no cruzamento 4; na avaliação do terceiro ano variaram de 85,80 a 96,87cm nos cruzamentos 3 e 4, respectivamente; e na avaliação do quarto ano, com parcela e número de repetições maiores, a variação foi de $74,05 \mathrm{~cm}$ no cruzamento 1 a $96,76 \mathrm{~cm}$ no cruzamento 4 . Ao contrário do caráter anterior, o maior tamanho da parcela não impossibilitou a comparação com os anos anteriores. Assim sendo, os dois cruzamentos que apresentaram as maiores médias quanto a altura das plantas na maturação na avaliação geral foram o 3 e o 4 .

Foi observado para ambos os caracteres, que o melhor cruzamento em um ano não era necessariamente o mesmo nos demais. Assim, através da melhor avaliação dos cruzamentos na safra de 1997/98, foi possível o ranqueamento dos cruzamentos para cada caráter, o que coincide perfeitamente com a ordenação realizada pela análise de média conjunta dos três primeiros anos de experimentação.

No ano agrícola de 1994/95, as médias da produção de grãos e da altura das plantas na maturação dos quatro cruzamentos foram muito inferiores quando comparadas às médias nos demais anos. Este fato pôde ser observado, também, através da análise de média por ano de todas as linhagens em avaliação. A média para a produção de grãos no primeiro e terceiro ano de plantio encontra-se na faixa de 200 $\mathrm{g} /$ parcela, enquanto que, no segundo ano a média está na faixa de $150 \mathrm{~g} /$ parcela, 
representando uma redução de $25 \%$, aproximadamente. Para a altura das plantas na maturação os resultados são similares, sendo o valor médio para a avaliação dos anos 1993/94, 1995/96 e 1997/98 foi aproximadamente de $85 \mathrm{~cm}$, enquanto que, no ano $1994 / 95$ foi de $63 \mathrm{~cm}$, significando uma redução de $25 \%$, aproximadamente.

As médias dos genitores dos cruzamentos, isto é, OC-79230, BR808858, BR80-14853, PI-165896 e PI-239235, para os caracteres produção de grãos e altura das plantas na maturação, estão apresentadas na Tabela 6. Observa-se, através da avaliação do ano 1997/98, que os genitores mais produtivos são BR80-8858 e BR8014853, que são os genitores do cruzamento de maior média do caráter, enquanto que, o genitor menos produtivo é a linhagem introduzida PI-165896, que faz parte do cruzamento que apresenta menor média deste caráter, conforme dados já apresentados na Tabela 5 e discutidos anteriormente.

Para a altura das plantas na maturação, os genitores mais altos são as linhagens PI-165853 e PI-239235, que fazem parte dos dois cruzamentos que apresentaram as maiores médias de altura. Ao contrário, as linhagens que apresentaram as menores médias de altura são genitores do cruzamento OC-79230 X BR80-8858, que apresentou a menor média para este caráter.

Fazendo-se uma comparação das médias entre as linhagens dos cruzamentos e as médias das testemunhas, apresentadas na Tabela 7, observa-se que as médias para o caráter produção de grãos dos cruzamentos 1,2 e 4 foram superiores a todas as testemunhas na avaliação do ano 1993/94. No ano seguinte, a média do melhor cruzamento (4) não suplantou as testemunhas mais produtivas, IAC-5, IAC Foscarin 31 e IAC-12. No terceiro ano de avaliação, apenas o cruzamento 2 apresentou média superior às testemunhas utilizadas, e praticamente igual à testemunha BR80-14887, que apresentou média de 253,29 g/parcela. No experimento da safra 1997/98, os cruzamentos 1,2 e 4 foram superiores às testemunhas, exceto à IAC-8, que apresentou média bem superior. 
Para a altura das plantas na maturação, a comparação não se faz apropriada, visto que as testemunhas empregadas neste trabalho não tem por finalidade a comparação para este caráter.

Os coeficientes de variação experimental $\left(\mathrm{CV}_{\mathrm{e}}\right)$ representam a precisão experimental. Portanto, quanto menor o seu valor, melhor será realizado o processo de avaliação e seleção de linhagens superiores, devido a melhor precisão das médias. Na Tabela 8, estão apresentados os valores dos coeficientes de variação experimental dos caracteres produção de grãos e altura das plantas na maturação para os quatro cruzamentos, obtidos das análises de variância agrupadas.

Foi possível separar os caracteres avaliados em dois grupos, quanto à magnitude da precisão experimental, nos quatro cruzamentos. $O$ caráter que apresentou o menor coeficiente de variação experimental ou a menor precisão experimental foi a altura das plantas na maturação, com o coeficiente de variação experimental variando de $8,1 \%$ a $12,9 \%$ na média dos quatro anos. Estes resultados indicam uma boa precisão nos processos de avaliação e seleção de linhagens superiores. Estes valores coincidem com os encontrados por ZIMBACK (1992). Ao contrário, o caráter produção de grãos apresentou o coeficiente de variação em torno de $23,6 \%$ a $33,8 \%$ na média dos quatro anos, devido ao fato deste caráter ser mais influenciado pelo ambiente que a altura de plantas na maturação. Estes altos valores indicam uma menor precisão na avaliação e seleção de linhagens mais produtivas.

Foi observado que nos dois primeiros anos de experimentação (1993/94 e 1994/95), a precisão experimental média dos quatro cruzamentos não alterou significativamente para ambos caracteres. Os coeficiente de variação experimental encontrados foram de aproximadamente $33,5 \%$ para a produção de grãos e, entre $11 \%$ e $13 \%$ para a altura das plantas na maturação. Entretanto, houve uma melhoria das condições experimentais a partir do ano agrícola de 1995/96, quando o CVe para a produção de grãos reduziu de 33\% em 1994/95 para 26\%, aproximadamente, em 1995/96 e para 23,5\% em 1997/98, assim como, para o caráter altura de plantas na 
maturação onde o CVe decresceu de 12,9\% em 1994/95 para 10,6\% em 1995/96 e na avaliação seguinte para $8,2 \%$.

\subsection{Análise de Variância}

As análises de variância dos caracteres produção de grãos e altura das plantas na maturação dos cruzamentos (1) OC-79230 X BR80-8858, (2) BR80-8858 X BR80-14853, (3) BR80-14853 X PI-165896 e (4) BR80-14853 X PI-239235 em cada um dos anos de avaliação, estão apresentadas nas Tabelas 9 e 10, respectivamente. A variação no número de graus de liberdade deve-se à ocorrência de parcelas perdidas, ao número diferente de linhagens dentro de cada cruzamento e ao número diferente de repetições no ano de 1997/98.

O teste de homocedasticidade dos quadrados médios foi aplicado para avaliar a possibilidade de reunião dos quatro ou cinco conjuntos, dependendo de cada um dos cruzamentos em estudo e, consequentemente, avaliar a possibilidade de realização das análises de variância agrupadas, bem como, realizar as análises conjuntas dos três primeiros anos de experimentação. Foi observado que, o quociente entre o maior e o menor quadrado médio do erro experimental para produção de grãos e altura das plantas na maturação, em cada um dos quatro anos de experimentação, não foi superior ao valor sete. O maior valor verificado foi de 6,67 para o caráter produção de grãos, no cruzamento 1 no ano 1993/94. Para a realização das análises conjuntas dos três primeiros anos de experimentação, em ambos caracteres, em nenhum dos cruzamentos o quociente foi superior a sete. As análises agrupadas e conjuntas foram, portanto, normalmente realizadas, reunindo-se os conjuntos dos cruzamentos nos quatro anos de avaliação e os três primeiros anos de cada cruzamento.

\subsection{Análises Genéticas}

Uma população homozigótica apresenta apenas um componente de variância, a variância genética aditiva. Portanto, as estimativas da variância genética 
serão relatadas como variância genética aditiva, já que as linhagens dos quatro cruzamentos em estudos estão em homozigose.

\subsubsection{Produção de grãos}

Para o caráter produção de grãos, as análises de variância dos quatro cruzamentos, nos anos 1993/94, 1994/95, 1995/96 e 1997/98, revelaram que os quadrados médios para as linhagens dos cruzamentos em cada um dos anos de avaliação foram significativos ( $\mathrm{P} \leq 1 \%$ ), com exceção daqueles referentes aos cruzamentos 1 e 4, que foram significativos ao nível de $5 \%$ de probabilidade, conforme apresentado na Tabela 9. Estes dados indicam a existência de suficiente variabilidade genética nos cruzamentos em questão e, consequentemente, possibilidade de seleção de linhagens mais produtivas.

As análises de variâncias conjuntas para os três primeiros anos de experimentação (1993/94, 1994/95 e 1995/96), nos quatro cruzamentos apresentados na Tabela 11, revelam que os quadrados médios para o efeito de anos foi altamente significativo ( $\mathrm{P} \leq 1 \%$ ) em todos os cruzamentos. Indicando a existência de anos que atuaram diferentemente para o desempenho produtivo das linhagens e confirmando a análise de média discutida anteriormente através da Tabela 5. Os quadrados médios da interação de linhagens com anos de avaliação mostraram-se, também, altamente significativos ( $\mathrm{P} \leq 1 \%$ ) em todos os cruzamentos, demonstrando que o desempenho das linhagens não foi consistente nos vários anos. Os quadrados médios para o efeito de linhagens foi significativo ( $\mathrm{P} \leq 1 \%$ ) para o cruzamento 2 , também significativo a um menor grau de significância (P $\leq 5 \%)$ para o cruzamento 3 . Em ambos os casos indica a existência de variabilidade genética e possibilidade de seleção de linhagens superiores para o caráter. Os quadrados médios para o efeito de linhagens não apresentou significância ao nível de $5 \%$ para os cruzamentos 1 e 4 , indicando uma menor magnitude da variabilidade genética. Convém lembrar que, os quadrados médios dos 
cruzamentos 1 e 4 foram os únicos que apresentaram um menor nível de significância (P $\leq 5 \%$ ) na análise agrupada para conjuntos no ano 1995/96.

$\mathrm{Na}$ Tabela 12 são apresentadas, para os quatro cruzamentos, as estimativas da variância genética aditiva entre linhagens e da variância do erro experimental entre parcelas, com seus respectivos intervalos de confiança, que dão uma idéia dos erros associados às estimativas. As estimativas da variância genética aditiva entre linhagens não apresentaram uma estabilidade nos quatro cruzamentos, na avaliação dos quatro anos. A ordenação dos cruzamentos baseada nas estimativas da variância genética aditiva, também não apresentou uma estabilidade ao longo dos anos. No primeiro ano de avaliação dos cruzamentos, a seqüência decrescente da variância genética aditiva entre linhagens obedeceu a seguinte ordem: cruzamentos $2,4,1$ e 3, sendo o maior valor igual a $2.550,793$ (g/parcela) ${ }^{2}$ e o menor igual a $1.432,636$ $(\mathrm{g} / \text { parcela })^{2}$. No ano seguinte a ordem dos cruzamentos foi 2, 1, 3 e 4, sendo o maior valor igual a 1.354,092 (g/parcela $)^{2}$ e o menor igual a 853,760 (g/parcela) ${ }^{2}$. Em 1995/96, a seqüência decrescente da ordem dos cruzamentos foi 3, 2, 4 e 1, sendo o maior valor igual a 2.229,823 (g/parcela $)^{2}$ e o menor igual a 351,387 (g/parcela) ${ }^{2}$. No ano 1997/98, cuja avaliação foi mais precisa, baseada em parcela de tamanho maior e maior número de repetições, a seqüência dos cruzamentos foi 4, 3, 2 e 1, onde o maior valor igual a $3.698,100(\mathrm{~g} / \text { parcela })^{2}$ e o menor igual a $1.597,765(\mathrm{~g} / \text { parcela })^{2}$.

Através das análises de variância conjuntas dos três primeiros anos de experimentação compiladas na Tabela 14, as estimativas das variâncias genética aditiva entre linhagens apresentaram a seguinte seqüência em ordem decrescente dos cruzamentos: 2, 3, 4 e 1, sendo o maior valor igual a 449,610 (g/parcela) ${ }^{2}$ e o menor igual a 108,125 (g/parcela $)^{2}$. Portanto, em nenhuma das cinco análises realizadas para 0 caráter produção de grãos, quatro individuais por ano e uma conjunta de três anos, ocorreu a mesma ordenação dos cruzamentos com base na variabilidade entre linhagens. Entretanto, pode-se separar os cruzamentos em dois grupos, os de maior variabilidade (3 e 2) e os de menor variabilidade (4 e 1 ). 
Os cruzamentos apresentaram as estimativas das variâncias da interação de linhagens com anos com valores muito próximos, sendo o maior igual a $1.172,481$ (g/parcela $)^{2}$ e o menor igual a $1.109,527(\mathrm{~g} / \text { parcela })^{2}$. Pode-se considerar que a interação de linhagens com anos foi de mesma magnitude para os quatro cruzamentos. Por outro lado, as estimativas das variâncias do erro experimental entre parcelas, com os respectivos limites superiores e inferiores, também relatados na Tabela 14, apresentaram o maior valor igual a 4.516,450 (g/parcela) ${ }^{2}$ para o cruzamento 2 e o menor valor de $2.637,770(\mathrm{~g} / \text { parcela })^{2}$ para o cruzamento 3 .

As estimativas dos coeficientes de variação genético, descritos na Tabela 15, corroboram com a idéia de agrupamento dos cruzamentos pela existência de menor ou maior variabilidade genética. $\mathrm{O}$ coeficiente de variação genético oscilou entre $19,73 \%$ e $22,24 \%$, indicando a liberação moderadamente constante da quantidade da variância genética aditiva nos quatro cruzamentos em 1993/94. No ano seguinte, esta estimativa oscilou de 19,19\% a 25,29\%, também apresentando-se moderadamente constante. Em 1995/96, a oscilação variou de $8,75 \%$ no cruzamento 1 a $32,73 \%$ no cruzamento 3. Na avaliação do ano 1997/98, a estimativa do coeficiente de variação genético variou de $11,23 \%$ no cruzamento 1 a $25,69 \%$ no cruzamento 3 . Na análise conjunta dos três primeiros anos, a estimativa do coeficiente de variação genético variou de aproximadamente $5,50 \%$ para os cruzamentos 1 e 4 , a $9,80 \%$ e $12,06 \%$ para os cruzamentos 2 e 3, respectivamente. Estes resultados indicam uma maior variabilidade nestes dois últimos cruzamentos, coincidindo com os relatos já apresentados anteriormente.

$\mathrm{Na}$ Tabela 16 estão representadas as estimativas dos coeficientes de herdabilidade e seus respectivos intervalos de confiança. Na avaliação do ano 1993/94, as estimativas dos coeficientes de herdabilidade apresentaram uma variação de 48,79\% a $61,60 \%$ para os cruzamentos 3 e 1, respectivamente. No segundo ano, os valores oscilaram entre 53,62\% e 59,73\%. Já, nas avaliações dos anos 1995/96 e 1997/98, as oscilações foram superiores às anteriormente observadas, variando de 33,49\% a 76,35\% e de $59,93 \%$ a $81,13 \%$ nos cruzamento 1 e 3 em ambos os anos, respectivamente. Estes 
resultados são superiores aos valores encontrados por JOHNSON et al. (1955a) e JOHNSON \& BERNARD (1963), e coincidem com os valores encontrados por SHANNON et al. (1972). Através da análise conjunta dos três primeiros anos, as estimativas dos coeficientes de herdabilidade puderam ser agrupadas em dois grupos. $\mathrm{O}$ primeiro, reuniu os cruzamentos 2 e 3 que apresentaram os valores das estimativas do coeficiente de herdabilidade da ordem de $33 \%$. O segundo grupo, composto pelos demais cruzamentos, apresentou os valores da estimativa deste componente da ordem de $13,4 \%$. É notado que os valores referentes às estimativas de herdabilidade obtidos da análise conjunta dos três anos foram muito inferiores aos obtidos no ano de melhor avaliação e melhor precisão experimental, ou seja, em 1997/98. Este fato é decorrente da estimativa obtida da análise conjunta estar isenta do efeito da interação de linhagens com anos, a qual apresenta magnitude elevada em todos os cruzamentos, pois o caráter produção de grãos é altamente influenciado pelo ambiente.

\subsubsection{Altura da planta na maturação}

Para o caráter altura das plantas na maturação, as análises de variância agrupadas para conjuntos dos quatro cruzamentos, nos anos 1993/94, 1994/95, 1995/96 e 1997/98, revelaram que os quadrados médios para as linhagens de todos os cruzamentos em cada um dos anos de avaliação foram altamente significativos ( $\mathrm{P} \leq 1$ \%), conforme apresentados na Tabela 10. Estes dados indicam a existência de suficiente variabilidade genética nos cruzamentos em questão e, consequentemente, possibilidade de seleção de linhagens com altura superior.

As análises de variância conjuntas para os três primeiros anos de experimentação (1993/94, 1994/95 e 1995/96), nos quatro cruzamentos, apresentados na Tabela 11 revelam que os quadrados médios para o efeito de anos foi altamente significativo ( $\mathrm{P} \leq 1 \%$ ) em todos os cruzamentos estudados, indicando a existência de anos que atuaram diferentemente para o desempenho das linhagens. Os quadrados médios da interação de linhagens com anos mostraram-se, também, altamente 
significativos $(\mathrm{P} \leq 1 \%)$ nos quatro cruzamentos, demonstrando que o desempenho das linhagens não foi consistente nos vários anos. Nível de significância idêntico ( $\mathrm{P} \leq 1 \%)$ apresentaram os quadrados médios para o efeito de linhagens em todos os cruzamentos, indicando a existência de variabilidade genética e possibilidade de seleção de linhagens superiores para o caráter.

$\mathrm{Na}$ Tabela 13 são apresentados, para os quatro cruzamentos, as estimativas da variância genética aditiva entre linhagens e da variância do erro experimental entre parcelas, com seus respectivos intervalos de confiança, que dão uma idéia dos erros associados às estimativas. A ordenação dos cruzamentos baseados nas estimativas da variância genética aditiva entre linhagens apresentaram uma boa estabilidade nos quatro cruzamentos na avaliação dos quatro anos. $\mathrm{Na}$ avaliação dos quatro cruzamentos nos anos 1993/94, 1995/96 e 1997/98 a seqüência decrescente das estimativas da variância genética aditiva entre linhagens obedeceu a seguinte ordem dos cruzamentos: (3) BR80-14853 X PI-165896, (4) BR80-14853 X PI-239235, (2) BR808858 X BR80-14853 e (1) OC-79230 X BR80-8858. Os maiores valores desta estimativa foram iguais a $684,788 \mathrm{~cm}^{2}, 145,858 \mathrm{~cm}^{2}$ e $689,644 \mathrm{~cm}^{2}$ para o cruzamento 3 , enquanto os menores valores foram iguais a $20,158 \mathrm{~cm}^{2}, 29,999 \mathrm{~cm}^{2}$ e $103,231 \mathrm{~cm}^{2}$ para o cruzamento 1, respectivamente nos anos citados. Na avaliação do ano 1994/95, ocorreu uma inversão na ordenação decrescente da estimativa da variância genética aditiva entre linhagens dos cruzamentos 2 e 1 . Portanto, neste ano a seqüência foi 3, 4, 1 e 2 , sendo o maior valor igual a $271,245 \mathrm{~cm}^{2}$ e o menor, $40,595 \mathrm{~cm}^{2}$.

Através das análises de variância conjuntas dos três primeiros anos de experimentação, compiladas na Tabela 14 , as estimativas das variâncias genética aditiva entre linhagens para o caráter altura de plantas na maturação apresentaram a seguinte seqüência em ordem decrescente dos cruzamentos: 3, 4, 2 e 1, sendo os valores deste componente de variância, para os referidos cruzamentos, iguais a $288,525 \mathrm{~cm}^{2}, 107,273$ $\mathrm{cm}^{2}, 52,488 \mathrm{~cm}^{2}$ e $21,404 \mathrm{~cm}^{2}$. Portanto, em apenas uma das cinco análises realizadas para o caráter altura das plantas na maturação, quatro individuais por ano e uma conjunta de três anos, não ocorreu a mesma ordenação dos cruzamentos com base na 
variabilidade entre linhagens. Assim sendo, pode-se separar os cruzamentos em dois grupos, os de maior variabilidade ( 3 e 4 ) e os cruzamentos de menor variabilidade ( 2 e 1).

Os cruzamentos apresentaram as estimativas das variâncias da interação de linhagens com anos com valores relativamente discrepantes, sendo o maior igual a $80,830 \mathrm{~cm}^{2}$ para o cruzamento 3 e o menor igual a $8,031 \mathrm{~cm}^{2}$ para o cruzamento 1. Pode-se considerar que a interação de linhagens com anos não foi a mesma para os quatro cruzamentos, ou seja, as linhagens de cada cruzamento tiveram um comportamento diferenciado com relação aos anos. As estimativas das variâncias do erro experimental entre parcelas, com os respectivos intervalos de confiança, também relatados na Tabela 14 , apresentaram como valor superior $98,348 \mathrm{~cm}^{2}$ e como inferior $55,220 \mathrm{~cm}^{2}$.

As estimativas dos coeficientes de variação genético, descritos na Tabela 15, corroboram com a idéia de agrupamento dos cruzamentos pela existência de menor ou maior variabilidade genética. $O$ coeficiente de variação genético oscilou de $6,27 \%$ para o cruzamento 1 a $29,80 \%$ para o cruzamento 3 , indicando a liberação diferenciada da quantidade da variância genética aditiva nos quatro cruzamentos em 1993/94. No ano seguinte, esta estimativa oscilou de $10,71 \%$ para o cruzamento 2 a $23,88 \%$ para o cruzamento 3 . Em $1995 / 96$, a oscilação variou de $6,21 \%$ para o cruzamento 1 a 14,08\% para o cruzamento 3 . Na avaliação do ano 1997/98, a estimativa do coeficiente de variação genético variou de $11,88 \%$ no cruzamento 2 a $29,15 \%$ no cruzamento 3. Através da análise conjunta dos três primeiros anos, as estimativas dos coeficientes de variação genético variaram na faixa de $6,38 \%$ a $9,63 \%$ para os cruzamentos 1 e 2 ; e de $12,24 \%$ a $21,06 \%$ para os cruzamentos 4 e 3 , respectivamente. Estes dados indicam uma maior variabilidade nestes dois últimos cruzamentos, coincidindo com os relatos já apresentados anteriormente.

Na Tabela 16 estão as estimativas dos coeficientes de herdabilidade, que apresentaram uma variação de $58,71 \%$ a $94,38 \%$, nos cruzamentos 1 e 3, 
respectivamente, na avaliação do ano 1993/94. No segundo ano, os valores oscilaram entre $59,82 \%$ e $92,97 \%$, ao passo que, nas avaliações dos anos 1995/96 e 1997/98, as diferenças entre as maiores e menores estimativas dos coeficientes de herdabilidade foram inferiores às anteriormente observadas, variando de $54,64 \%$ a $82,17 \%$ e de $90,89 \%$ a $98,61 \%$, respectivamente. Através da análise conjunta dos três primeiros anos, as estimativas dos coeficientes de herdabilidade apresentaram valores altos e moderadamente semelhantes. Os valores para os cruzamentos 1, 2, 3 e 4 foram respectivamente, $70,84 \% ; 79,23 \% ; 88,40 \%$ e $87,36 \%$. Pode-se observar que os valores referentes às estimativas de herdabilidade obtidos da análise conjunta dos três anos foram inferiores aos obtidos no ano de melhor avaliação e precisão experimental, ou seja, no quarto ano de experimentação. Este fato é decorrente da estimativa obtida da análise conjunta estar isenta do efeito da interação de linhagens com anos. Entretanto, a redução destas estimativas foram inferiores ao ocorrido com o caráter produção de grãos, pois a altura das plantas na maturação é menos influenciada pelo ambiente.

\subsection{Métodos de seleção}

Na Tabela 17 são apresentadas as médias dos caracteres produção de grãos e altura das plantas na maturação das linhagens iniciais, ou seja, o conjunto total de linhagens que integram cada etapa do processo seletivo dentro de cada cruzamento, bem como, a média das linhagens selecionadas em cada etapa de seleção, com seus respectivos diferenciais de seleção, para cada cruzamento nos dois métodos de seleção (Independente e Seqüencial).

Nos dois métodos de seleção empregados em 1993/94, onde foram selecionadas $70 \%$ do número de linhagens de cada cruzamento, as médias das linhagens iniciais e selecionadas foram idênticas. Isto ocorreu pois, a metodologia de seleção empregada em ambos métodos foi a mesma. As médias, em g/parcela, das linhagens iniciais e selecionadas para produção de grãos nos cruzamentos (1) OC-79230 X BR808858, (2) BR80-8858 X BR80-14853, (3) BR80-14853 X PI-165896 e (4) BR80-14853 
X PI-239235 foram 210,47 e 236,03; 255,99 e 288,04; 178,93 e 199,25 e, 222,33 e 249,87, respectivamente. Assim sendo, os diferenciais de seleção foram 25,56 g/parcela, $32,05 \mathrm{~g} /$ parcela, 20,32 g/parcela e 27,54 g/parcela, respectivamente. Para a altura das plantas na maturação, as médias das linhagens iniciais e selecionadas foram $71,56 \mathrm{~cm}$ e $74,24 \mathrm{~cm}$ para o cruzamento $1,77,01 \mathrm{~cm}$ e $81,14 \mathrm{~cm}$, para o cruzamento $2,87,82 \mathrm{~cm}$ e $98,43 \mathrm{~cm}$ para o cruzamento 3 e para o cruzamento $4,87,91 \mathrm{~cm}$ e $92,15 \mathrm{~cm}$. Os diferenciais de seleção foram $2,68 \mathrm{~cm}, 4,13 \mathrm{~cm}, 10,61 \mathrm{~cm}$ e $4,24 \mathrm{~cm}$, para os cruzamentos $1,2,3$ e 4 , respectivamente.

No processo seletivo dos anos subsequentes, as médias nos dois métodos não foram coincidentes, como era de se esperar, já que a seleção das linhagens foi realizada de forma diferente. Mesmo que fossem selecionadas as mesmas linhagens pelos dois métodos, as médias seriam diferentes, pois o método Independente leva em conta apenas a avaliação de um ano e o método Seqüencial baseia-se na avaliação dos anos disponíveis.

As médias das linhagens iniciais do método de seleção Independente em 1994/95 foram compostas pela avaliação neste ano das linhagens selecionadas em 1993/94 e, a média das linhagens selecionadas foram compostas pela seleção das 50\% melhores linhagens avaliadas em 1994/95. Portanto, as médias de produção de grãos, em g/parcela, das linhagens iniciais e selecionadas foram 151,92 e 189,75 para o cruzamento $1 ; 149,44$ e 188,38 , para o cruzamento $2 ; 136,06$ e 161,73 , para o cruzamento 3, e para o cruzamento 4, 152,19 e 177,95 g/parcela. Os diferenciais de seleção encontrados para os mesmos cruzamentos foram iguais a 37,83 g/parcela, 38,94 g/parcela, 25,67 g/parcela e 25,76 g/parcela. Para a altura das plantas na maturação, as médias, em centímetros, das linhagens iniciais e selecionadas foram 58,19 e 64,28 para o cruzamento 1, 61,37 e 66,85 para o cruzamento 2, 74,30 e 84,82 para o cruzamento 3 , e para o cruzamento $4,71,07$ e $76,49 \mathrm{~cm}$. Os diferenciais de seleção foram $6,09 \mathrm{~cm}$, $5,48 \mathrm{~cm}, 10,52 \mathrm{~cm} \mathrm{e} 5,42 \mathrm{~cm}$ para os cruzamentos $1,2,3$ e 4 , respectivamente. 
Para o método de seleção Seqüencial, as médias de produção de grãos das linhagens iniciais e selecionadas em 1994/95 para os cruzamentos 1, 2, 3 e 4 foram 193,42 e $217,72 \mathrm{~g} /$ parcela; 216,66 e $246,73 \mathrm{~g}$ /parcela; 165,49 e $188,28 \mathrm{~g} /$ parcela e, 199,20 e 223,15 g/parcela, respectivamente. Os diferenciais de seleção para os mesmos cruzamentos foram iguais a 24,30 g/parcela, 30,07 g/parcela, 22,79 g/parcela e 23,95 $\mathrm{g} /$ parcela. Para a altura das plantas na maturação, as médias das linhagens iniciais e selecionadas foram $66,04 \mathrm{~cm}$ e $70,14 \mathrm{~cm}$ para o cruzamento $1,70,91 \mathrm{~cm}$ e $76,44 \mathrm{~cm}$ para o cruzamento $2,85,84 \mathrm{~cm}$ e $99,81 \mathrm{~cm}$ para o cruzamento 3 e $81,19 \mathrm{~cm}$ e $87,87 \mathrm{~cm}$ para o cruzamento 4 . Os diferenciais de seleção foram $4,10 \mathrm{~cm}, 5,53 \mathrm{~cm}, 13,97 \mathrm{~cm}$ e $6,68 \mathrm{~cm}$ para os cruzamentos $1,2,3$ e 4 , respectivamente.

Pode-se observar que, tanto para a produção de grãos quanto para a altura das plantas na maturação, em todos os cruzamentos, as médias das linhagens iniciais e selecionadas pelo método Seqüencial foram superiores às respectivas médias obtidas pelo método Independente em 1994/95. Este fato ocorreu devido ao efeito de anos, cujas médias de 1994/95 para ambos caracteres em todos os cruzamentos foram inferiores aos demais. Para o método Independente as médias obtidas referem-se apenas ao ano em questão, cujos valores são menores. Por outro lado, no método Seqüencial as médias obtidas referem-se à avaliação de dois anos, sendo diluído o efeito negativo do ano 1994/95.

O processo seletivo realizado em 1995/96 ocorreu de maneira semelhante à seleção feita em 1994/95, em cada um dos dois métodos, onde a seleção pelo método Independente foi realizada nas linhagens selecionadas da avaliação de 1994/95, baseada apenas no desempenho destas em 1995/96. A seleção realizada pelo método Seqüencial foi realizada nas linhagens selecionada no ano anterior, levando-se em conta o desempenho conjunto das linhagens nos três anos de avaliação, ou seja, 1993/94, 1994/95 e 1995/96. Em 1995/96, foram selecionadas $42,9 \%$ das linhagens avaliadas dentro de cada cruzamento, o que perfaz uma intensidade de seleção final de $15 \%$. 
As médias para o caráter produção de grãos das linhagens iniciais e selecionadas do método de seleção Independente, avaliadas em 1995/96, para o cruzamento 1 foram iguais a 223,07 e 248,07 g/parcela com o diferencial de seleção (ds) de 25,00 g/parcela; para o cruzamento 2 as médias foram 255,99 e 285,96 g/parcela com ds igual a 30,46 g/parcela; para o cruzamento 3 as médias foram 155,82 e 212,43 $\mathrm{g} /$ parcela com ds de 56,61 g/parcela e para o cruzamento 4 as médias foram 197,46 e $216,59 \mathrm{~g} /$ parcela, com ds de 19,13 g/parcela, respectivamente. Para a altura das plantas na maturação, as médias das linhagens iniciais, das selecionadas e os respectivos diferenciais de seleção foram $92,35 \mathrm{~cm}, 97,78 \mathrm{~cm}$ e $5,43 \mathrm{~cm}$ para o cruzamento 1; $94,38 \mathrm{~cm}, 101,02 \mathrm{~cm}$ e $6,64 \mathrm{~cm}$ para o cruzamento $2 ; 95,19 \mathrm{~cm}, 101,46 \mathrm{~cm}$ e $6,27 \mathrm{~cm}$ para o cruzamento 3 e para o cruzamento $4,106,64 \mathrm{~cm}, 120,89 \mathrm{~cm}$ e $14,25 \mathrm{~cm}$.

Na seleção realizada em 1995/96 pelo método Seqüencial, as médias da produção de grãos, em g/parcela, das linhagens iniciais, selecionadas e diferenciais de seleção para a produção de grãos foram 220,47, 234,91 e 14,44; 249,48, 267,16 e 17,$68 ; 176,15,197,06$ e 20,91 e, 214,97, 229,22 e 14,25 g/parcela para os cruzamentos 1, 2, 3 e 4, respectivamente. Para a altura das plantas na maturação, as médias das linhagens iniciais e selecionadas foram $78,01 \mathrm{~cm}$ e $81,62 \mathrm{~cm}$ para o cruzamento 1 , $82,61 \mathrm{~cm}$ e $86,14 \mathrm{~cm}$ para o cruzamento $2,98,67 \mathrm{~cm}$ e $103,48 \mathrm{~cm}$ para o cruzamento 3 e $94,43 \mathrm{~cm}$ e $103,84 \mathrm{~cm}$ para o cruzamento 4 . Os diferenciais de seleção foram $3,61 \mathrm{~cm}$, $3,53 \mathrm{~cm}, 4,81 \mathrm{~cm} \mathrm{e} 9,41 \mathrm{~cm}$, para os cruzamentos $1,2,3$ e 4, respectivamente.

De maneira inversa à observação realizada no ano 1994/95 com relação às médias obtidas de ambos caracteres nos dois métodos de seleção, em 1995/96 as médias para o método Seqüencial foram, no geral, inferiores às respectivas médias do método Independente. Para o método Independente as médias referem-se apenas ao ano em questão, cujos valores são superiores, ou seja, um ano favorável ao desenvolvimento e produtividade da soja, enquanto que, no método Seqüencial as médias referem-se à avaliação de três anos, composto, também, pelo efeito negativo do ano 1994/95, que reduziu a média. 
A avaliação comparativa de todas as linhagens de cada cruzamento com apenas as linhagens selecionadas ao final do processo seletivo realizado em cada um dos dois métodos de seleção, na avaliação experimental de 1997/98, estão compiladas na Tabela 18, para os caracteres produção de grãos e altura de plantas na maturação. Considera-se esta análise como a mais precisa, pois as parcelas experimentais e o número de repetições foram maiores, além de apresentar os menores coeficientes de variação experimental.

As médias para o caráter produção de grãos de todas as linhagens dos cruzamentos 1, 2, 3 e 4, na avaliação de 1997/98, foram iguais a 356,09 g/parcela, $387,53 \mathrm{~g} /$ parcela, 215,33 g/parcela e 346,95 g/parcela, respectivamente. Assim sendo, a ordenação decrescente dos cruzamentos na avaliação deste ano, coincidiu com a ordenação obtida pela análise conjunta dos três primeiros anos, ou seja, cruzamentos 2 , 1, 4 e 3. O ganho com seleção para o método Independente foi negativo com valor de $4,54 \mathrm{~g} /$ parcela para o cruzamento 1 e positivo para os demais, com valores de 34,11 $\mathrm{g} /$ parcela, 41,76 g/parcela e 38,56 g/parcela nos cruzamentos 2,3 e 4, respectivamente. Enquanto que, para o método Seqüencial os ganhos com seleção foram superiores aos obtidos pelo método Independente, nos quatro cruzamentos, apresentando valores de $17,04 \mathrm{~g} /$ parcela, para o cruzamento $1 ; 35,22 \mathrm{~g} /$ parcela para o cruzamento $2 ; 44,68$ g/parcela para o cruzamento 3 , e para o cruzamento 4 , o ganho com seleção para o método Seqüencial foi de $48,11 \mathrm{~g}$ /parcela. As eficiências relativas com seleção foram favoráveis ao método Seqüencial com valores de $21,58 \mathrm{~g} /$ parcela para o cruzamento 1 , de $9,55 \mathrm{~g} /$ parcela para o cruzamento 4 , de 2,92 g/parcela para o cruzamento 3 , e para o cruzamento 2, de 1,11 g/parcela. Portanto, para o caráter produção de grãos, a eficiência relativa com seleção foi favorável ao método Seqüencial, em todos os cruzamentos.

As comparações das frequências das linhagens selecionadas pelos dois métodos de seleção nos cruzamentos 1, 2, 3 e 4, divididas em classes de distribuição para o caráter produção de grãos, na avaliação do ano 1997/98, podem ser visualizadas nas Figuras 1, 2, 3 e 4, respectivamente. Em todas as figuras pode-se observar um maior deslocamento para o lado direito da curva de distribuição na frequência de linhagens 
selecionadas pelo método Seqüencial em comparação ao método Independente. Isto indica uma melhor eficiência deste método na seleção de linhagens mais produtivas, reforçando os resultados da Tabela 18. Entretanto, o deslocamento da curva de distribuição de linhagens selecionadas superiores obtidas pelo método Seqüencial foi mais acentuado nos cruzamentos 1 e 4, respectivamente, assim como, os valores da eficiência relativa de seleção também foram superiores nestes dois cruzamentos.

Para observar de maneira prática o real potencial de seleção do método Seqüencial sobre o método Independente, faz-se necessário uma comparação das linhagens selecionadas em cada cruzamento em ambos os métodos de seleção com a média da testemunha mais produtiva, ou seja, IAC-8 com rendimento de 401,63 g/parcela na avaliação de 1997/98, através da distribuição em classes das linhagens selecionadas apresentadas nas Figuras 1, 2, 3 e 4.

O método Seqüencial mostrou ser mais eficiente na seleção de plantas mais produtivas nos quatro cruzamentos. Entretanto, apresentou-se ainda mais eficiente nos cruzamentos que dispunham de menor variabilidade genética, menor estimativa do coeficiente de variação genético e, consequentemente, menor coeficiente de herdabilidade, que foram os cruzamentos 1 e 4 . Isto ocorreu, devido o método Seqüencial avaliar melhor as linhagens no processo de seleção de linhagens mais produtivas.

Pode-se observar através da distribuição em classes de produção das linhagens do cruzamento 1, apresentada na Figura 1, três linhagens posicionaram-se em classes superiores à classe da testemunha mais produtiva (IAC-8) pelo método Seqüencial e, apenas, uma linhagem posicionou-se em classe superior à testemunha pelo método Independente, reforçando a melhor eficiência do método Seqüencial. Para o cruzamento 4, apresentado na Figura 4, seis linhagens posicionaram-se em classes superiores à classe da testemunha pelo método Independente e pelo método Seqüencial, cinco linhagens; entretanto, a linhagem mais produtiva foi selecionada pelo método Seqüencial. No cruzamento 3, apresentado na Figura 3, nenhuma linhagem foi superior 
à IAC-8. E, na Figura 2 que representa as classes de distribuição das linhagens selecionadas do cruzamento 2 , sete linhagens posicionaram-se em classes superiores à da testemunha mais produtiva em ambos os métodos de seleção. Portanto, de maneira geral, observa-se a maior eficiência relativa do método Seqüencial sobre o método Independente, na seleção de linhagens mais produtivas.

Na Tabela 18, são apresentadas as médias para o caráter altura de plantas na maturação de todas as linhagens dos quatro cruzamentos, na avaliação de 1997/98. Portanto, as médias deste caráter nos cruzamentos $1,2,3$ e 4 foram $74,05 \mathrm{~cm}$, $87,39 \mathrm{~cm}, 90,08 \mathrm{~cm}, 96,76 \mathrm{~cm}$, respectivamente. Assim sendo, a ordenação decrescente dos cruzamentos na avaliação deste ano, coincidiu com a ordenação obtida pelas análises anteriores, ou seja, cruzamentos $4,3,2$ e 1 . Os ganhos com seleção para o método Independente foram positivos nos quatro cruzamentos, ou seja, em todos os cruzamentos houve elevação da altura das plantas selecionadas em comparação com as população inicial; estes aumentos foram na ordem de $10,07 \mathrm{~cm}$ para o cruzamento 1 , de $10,68 \mathrm{~cm}$ para o cruzamento 2 , de $24,39 \mathrm{~cm}$ para o cruzamento 3 , e para o cruzamento 4 , de $16,80 \mathrm{~cm}$. De forma semelhante, o método Seqüencial apresentou os ganhos com seleção positivos nos quatro cruzamentos; entretanto, superiores aos obtidos pelo método Independente. Para o cruzamento 1 , o ganho com seleção foi de $12,74 \mathrm{~cm}$, de $15,80 \mathrm{~cm}$ para o cruzamento 2 , de $26,12 \mathrm{~cm}$ para o cruzamento 3 , e para o cruzamento 4 , o ganho com seleção para o método Seqüencial foi de $17,61 \mathrm{~cm}$. As eficiências relativas com seleção foram, em todos os cruzamentos, favoráveis ao método Seqüencial com valores de $5,12 \mathrm{~cm}$ para o cruzamento 2 , de $2,67 \mathrm{~cm}$ para o cruzamento 1 , de $1,73 \mathrm{~cm}$ para o cruzamento 3 , e para o cruzamento 4 , de $0,81 \mathrm{~cm}$. Portanto, para o caráter produção de grãos, a eficiência relativa com seleção foi favorável ao método Seqüencial, em todos os cruzamentos.

As comparações das frequências das linhagens selecionadas pelos dois métodos de seleção nos cruzamentos 1, 2, 3 e 4, divididas em classes de distribuição para o caráter altura das plantas na maturação, na avaliação do ano 1997/98, podem ser visualizadas nas Figuras 5, 6, 7 e 8, respectivamente. Em todas as figuras pode-se 
observar um maior deslocamento para o lado direito da curva de distribuição na frequência de linhagens selecionadas pelo método Seqüencial em comparação ao método Independente. Isto indica uma melhor eficiência deste método na seleção de linhagens com maior porte, reforçando os resultados apresentados e já discutidos na Tabela 18. Entretanto, o deslocamento da curva de distribuição de linhagens selecionadas superiores obtidas pelo método Seqüencial foi mais acentuado nos cruzamentos 2 e 1, respectivamente, assim como, os valores da eficiência relativa de seleção também foram superiores nestes dois cruzamentos.

De maneira semelhante à produção de grãos, para a altura de plantas na maturação o método Seqüencial mostrou ser mais eficiente na seleção de plantas com maior porte nos quatro cruzamentos. Entretanto, apresentou-se ainda mais eficiente nos cruzamentos que dispunham de menor variabilidade genética, menor coeficiente de variação genético e, consequentemente, menor coeficiente de herdabilidade que foram os cruzamentos 2 e 1 , respectivamente.

Portanto, a melhor eficiência de seleção do método Seqüencial em relação ao método Independente nos cruzamentos com menor variância genética aditiva, menor coeficiente de variação genético e menor herdabilidade, deve-se ao processo de avaliação das linhagens ao longo do tempo ser mais preciso, ou seja, pelo método Seqüencial as linhagens foram melhor avaliadas e, consequentemente, melhor selecionadas.

\subsection{Considerações finais}

Há a necessidade de melhorar a eficiência dos programas de melhoramento genético de soja, bem como, de todas as espécies que têm utilização na alimentação humana e animal, no sentido de desenvolver genótipos mais produtivos, mais adaptados às diversas regiões produtoras do Brasil, resistentes às pragas e doenças e com melhor qualidade nutricional, devido a crescente carência alimentar pela qual 
passa o mundo, aliada aos altos custos de produção e aos mercados cada vez mais competitivos.

A proposta desta tese encaixa-se perfeitamente neste cenário atual, onde o processo seletivo pode ser melhorado pela utilização da seleção baseada na avaliação em vários anos, sem aumentar os custos e o trabalho empregado, proporcionando aos agricultores cultivares mais produtivos e em menor tempo.

Com o estudo comparativo de dois métodos de seleção, um baseado na avaliação em vários anos (Seqüencial) e o outro baseado na avaliação de apenas um ano (Independente), realizado em quatro populações de soja, em dois caracteres, um de alta herdabilidade (altura das plantas na maturação) e o outro de baixa herdabilidade (produção de grãos), em quatro anos de avaliação, foi possível chegar a algumas considerações importantes, descritas a seguir.

As estimativas das interações de linhagens com anos para os caracteres produção de grãos e altura das plantas na maturação apresentaram valores completamente distintos. Para o caráter de menor herdabilidade (produção de grãos) as estimativas destas interações foram da ordem de três a dez vezes maiores que as estimativas das variâncias genética aditiva entre linhagens nos quatro cruzamentos, indicando a grande influência da interação no desempenho das linhagens em questão. Com estas informações, pode-se notar a grande dificuldade em avaliar e selecionar genótipos superiores, devido a alta interferência da interação. Uma metodologia que possa reduzir ou eliminar este efeito seria bastante útil num programa de melhoramento genético.

Para a altura das plantas na maturação, caráter que apresenta maior valor de herdabilidade, as estimativas das interações de linhagens com anos foram da ordem de três a seis vezes inferiores às estimativas das variâncias genética aditiva entre linhagens nos quatro cruzamentos, indicando a menor influência do efeito da interação no desempenho das linhagens em questão. Portanto, o processo de avaliação e seleção de linhagens para caracteres de alta herdabilidade é realizado com maior precisão. 
Os ganhos com seleção obtidos com o método de seleção Seqüencial foram em todos os casos, ou seja, nos quatro cruzamentos e em ambos caracteres, superiores aos ganhos obtidos pelo método de seleção Independente, o que pode ser observado através das equações seguintes que relacionam os fatores que atuam no ganho com seleção.

Seleção Independente: $\mathrm{Gs}=\mathrm{ds}\left(\frac{\sigma_{\mathrm{G}}^{2}}{\sigma_{\mathrm{G}}^{2}+\sigma_{\mathrm{GA}}^{2}+\frac{\sigma^{2}}{\mathrm{R}}}\right)$

Seleção Seqüencial: $\mathrm{Gs}=\mathrm{ds}\left(\frac{\sigma_{\mathrm{G}}^{2}}{\sigma_{\mathrm{G}}^{2}+\frac{\sigma_{\mathrm{GA}}^{2}}{\mathrm{~A}}+\frac{\sigma^{2}}{\mathrm{RA}}}\right)$

Pode-se observar que nos ganhos com seleção obtidos através do método de seleção Seqüencial, os efeitos prejudiciais da interação das linhagens com anos e do componente da variância ambiental são reduzidos, aumentando, assim, os ganhos com seleção. No processo de seleção Independente, estes componentes atuam integralmente, ou seja, tem máxima influência, reduzindo os ganhos com seleção. Entretanto, os ganhos obtidos com seleção foram mais pronunciados, em ambos caracteres, nas populações que apresentaram menor variabilidade genética e, consequentemente, menor coeficiente de herdabilidade.

Em apenas três etapas, a eficiência relativa de seleção do método Seqüencial com base no ganho com o método de seleção Independente foi da ordem de $3 \%$ a $24 \%$ para a produção de grãos e de $5 \%$ a $48 \%$ para a altura das plantas na maturação. Resultados semelhantes foram obtidos por Souza Jr. (1995) em trabalho de simulação, que apresentou eficiências relativas de $4,0 \%$ a $28,8 \%$ para caracter de alta e baixa herdabilidade, respectivamente, após três ciclos de seleção. 


\section{CONCLUSÕES}

Os resultados obtidos no presente trabalho permitiram apontar as seguintes conclusões:

a) Para ambos os caracteres ocorreu interação entre genótipos e anos; entretanto, esta foi bastante pronunciada para a produção de grãos e pouco pronunciada para a altura das plantas na maturação.

b) O método de seleção Seqüencial acarretou em um ganho com seleção maior que o método de seleção Independente para ambos caracteres nas quatro populações.

c) A eficiência do método Seqüencial foi mais acentuada nas populações com menor variabilidade genética e, consequentemente, menor coeficiente de herdabilidade.

d) O método de seleção Seqüencial, por ser mais eficiente, permite a aplicação de intensidades de seleção maiores, reduzindo o custo do programa ou possibilitando a avaliação de um número maior de genótipos com o mesmo custo.

e) O método de seleção Seqüencial é recomendado nos esquemas de melhoramento em que a seleção é feita em várias etapas e os genótipos estão fixados, como é o caso de populações homozigóticas de espécies autógamas. 


\section{REFERÊNCIAS BIBLIOGRÁFICAS}

ALLARD, R.W. Princípios do melhoramento genético de plantas. Trad. de A. Blumenschein, E. Paterniani, J. T. A. Gurgel e R. Vencovsky. Rio de Janeiro: Aliança para o progresso, 1971.

ALLARD, R.W.; BRADSHAW, A.D. Implications of genotype $\mathrm{x}$ environmental interactions in applied plant breeding. Crop Science, Madison, v.4, p.503-8. 1964.

ANAND, S.C.; TORRIE, J.H. Heritability of yield and other traits and interrelations among traits in the $F_{3}$ and $F_{4}$ generations of three soybean crosses. Crop Science, v.3, p.508-511, 1963.

BARBIN, D. Componentes de variância. Piracicaba: Escola Superior de Agricultura "Luiz de Queiróz" - Departamento de Matemática e Estatística, 1993. 108p.

BAYS, I.A. Heritability and association of several quantitative characters in segregating populations of soybeans (Glycine max (L,) Merrill). Mississippi, 1975. 91p. Thesis (Ph.D.) - Mississipi State University.

BONATO, E.R. Herança do tempo para o florescimento e para a maturidade em variantes naturais de soja (Glycine max (L.) Merrill). Piracicaba, 1989. 166p. Tese (Doutorado) - Escola Superior de Agricultura "Luiz de Queiroz", Universidade de São Paulo. 
BONETTI, L. P. Distribuição da soja no mundo; origem, botânica e distribuição, In: MIYASAKA, S.C.; MEDINA, S.C. (Ed). A soja no Brasil. Campinas: ITAL, 1981. p.1-6.

BRANCH, W.D.; HILDEBRAND, G.L. Pod yield comparison of pure-line peanut selections simultaneously developed from Georgia and Zimbabwe breeding programs. Plant Breeding, Berlin, v.102, p.260-3. 1989.

BRANCH, W.D.; KIRBY, J.S.; WYNNE, J.C.; HOLBROOK, C.C.; ANDERSON, W.F. Sequential vs. pedigree selection method for yield and leafspot resistance in peanut. Crop Science, Madison, v.31, n.2, p.274-6, 1991.

BRIM, C.A. Quantitative genetics and breeding. In: BERNARD, R.L.; WEISS, M.G. (Ed). Soybeans: improvement, production and uses. 2.ed. Madison: American Society ofAgronomy, 1973. cap.5, p.155-185.

BURTON, J.W. Breeding soybeans for improved protein quantity and quality. In: World Soybean Research Conference, 3., Ames, 1984. Proceedings, edited by R. SHIBLES. Boulder, Westview, 1984. p. 361-7.

BURTON, J. W. Quantitative genetics: results relevant to soybean breeding. In: WILCOX, J.R., (Ed). Soybeans: improvement, production and uses. 2.ed. Madison: American Society of Agronomy, 1987. cap.6, p.211-47.

BURTON, J.W. Breeding soybeans cultivars for increased seed protein percentage. In: World Soybean Research Conference, 4., Buenos Aires, 1989. Proceedings, edited by A.J. PASCALE. Buenos Aires, Orientación Gráfica, 1989. p. 1079-85.

BURTON, J.W. \& BRIM, C.A. Recurrent selection in soybeans. III. Selection for increased percent oil in seeds. Crop Science, v.21, p.31-34, 1981.

BYTH, D.E.; WEBER, C.A.; CALDWEL, B.E. Correlated truncation selection for yield in soybeans. Crop Science, v.9, p.699-702, 1969. 
CHAUHAN, V.S.; SINGH, B.B. Heterosis and genetics variability in relation to genetic divergence in soybean. Indian Journal of Genetic and Plant Breeding, v.42, n.3, p.324-328, Nov. 1982.

COWEN, N.M.; RODGERS, D.M.; FREY, K.J. Comparison of selection methods in oats (Avena sativa L.). Agronomy-abstracts, p.60, 1983.

CRUZ, C.D.; REGAZZI, A.J. Modelos biométricos aplicados ao melhoramento genético. Viçosa: Imprensa Universitária da UFV, 1994. 390p.

DUDLEY, J.W. \& MOLL, R.H. Interpretation and use of estimates of heritability and genetic variances in plant breeding. Crop Science, v.11, p.257-262, 1969.

ELGERSMA, A. Spaced plant traits related to seed yield in plots of perennial ryegrass (Lolium perenne L.). Euphytica, v.51, p.151-61. 1990.

EMBRAPA. Centro Nacional de Pesquisa de Soja. Recomendações técnicas para a cultura da soja na região Central do Brasil 1997/98. Londrina, 1998. 182p. (Embrapa-soja. Documento, 120).

ERICKSON, L.R.; BEVERSDORF, W.D.; BALL, S.T. Genotype $\mathrm{x}$ environment interactions for protein in Glycine $\max \times$ Glycine soja crosses. Crop Science, Madison, v.22, p.1099-101. 1982.

FALCONER, D.S. Introdução à genética quantitativa. Trad. de M. A. e Silva e J. C. Silva. Viçosa, UFV, Impre. Univ., 1987. 279p.

FEHR, W.R. Breeding methods for cultivar development. In: WILCOX, J. R., ed. Soybeans: improvement, production and uses. 2. Ed. Madison: ASA/CSSA/SSSA, 1987. p.249-293.

FEHR, W.R. Principles of cultivar development. v.1. Iowa State University. Macmillan Publishing Company. New York, 1987.487p. 
FEHR, W.R. \& WEBER, C.R. Mass selection by seed size and specific gravity in soybean populations. Crop Science, v.8, p.551-554, 1968.

FINNEY, D.J. Plant selection for yield improvement. Euphytica, Dordrecht, v.7, p.83-106. 1958.

FREIRE FILHO, F. R. Análise genética de um dialelo entre genótipos precoces de soja (Glycine max (L.) Merrill). Piracicaba, 1988. 224p. Tese (Doutorado) - Escola Superior de Agricultura “Luiz de Queiroz", Universidade de São Paulo.

GIECO, J.O. Interação genótipos $\mathrm{x}$ ambientes e implicações para o melhoramento da soja. Piracicaba, 1997. 98p. (Mestrado - Escola Superior de Agricultura "Luiz de Queiroz"(USP).

GOMES, F. P. Curso de estatística experimental. Piracicaba: Nobel, 1990. Cap. 8, p. 126-150: Análise de grupos de experimentos.

GOMES, R.L.F. Análise genética de progênies $\mathrm{F}_{6}$ e $\mathrm{F}_{7: 6}$ de soja obtidas de cruzamentos dialélicos. Piracicaba, 1995. 140p. Tese (Doutorado) - Escola Superior de Agricultura “Luiz de Queiroz", Universidade de São Paulo.

GUIMARÃES, E.P. Genetic improvement of soybean from populations developed by alternative recurrent selection strategies. Ames, 1985. 116p. (Doctor of Philosophy - Department of Agronomy - Iowa State University).

GUPTA, V.P.; GARG, I.K.; RANA, N.D. Genotype x environment interaction in soybean: I. Individual regression analysis. Soybean Genetics Newsletter, Ames, v.9, p.45-6. 1982a.

GUPTA, V.P.; GARG, I.K.; RANA, N.D. Genotype x environment interaction in soybean: II. Join regression analysis. Soybean Genetics Newsletter, Ames, v.9, p.47-50. $1982 b$. 
HADLEY, H.H.; HYMOWITZ, T. Speciation and cytogenetics. In: CALDWELL, B.E., ed. Soybeans: improvement, production and uses. Madison: American Society of Agronomy, 1973. Cap. 3, p.97-116. (Agronomy, 16).

HANSON, W.D. Heritability. In: HANSON, W.D. \& ROBINSON, H.F., (ed.) Statistical genetics and plant breeding. Washington, National Academy of Sciences. 1963. p.125-139.

HANSON, W.D.; LEFFEL, R.C.; HOWELL, R.W. Genetic analysis of energy production in the soybean. Crop Science, v.1, p.121-126, 1961.

HARTWIG, E.E. Breeding soybeans for high protein content and quality. In: INTERNATIONAL ATOMIC ENERGY AGENCY. New approaches to breeding for improved plant protein. Vienna, IAEA, 1969. P. 67-70.

HIROMOTO, D.M.; VELLO, N.A. The genetic base of Brazilian soybean (Glycine $\max ($ L.) Merrill) cultivars. Revista Brasileira de Genética, v.9, n.2, p.295-302, 1986.

HOLBROOK, C.C.; BURTON, J.W.; CARTER JUNIOR, T.E. Evaluation of recurrent restricted index selection for increasing yield while holding seed protein constant in soybean. Crop Science, v.29, p.324-329, 1989.

HYMOWITZ, T. On the domestication of soybean. Economic Botany, v.24, n.4, p.408-421, Oct./Dec. 1970.

JOHNSON, H.W. \& BERNARD, R.L. Soybean genetics and breeding. In: NORMAN, A.G., (ed.) The soybean genetics, breeding, physiology, nutrition, management. New York, Academic Press, 1963. p. 1-73.

JOHNSON, H.W.; ROBINSON, H.F.; COMSTOCK, R.E. Estimates of genetic and environmental variability in soybeans. Agronomy Journal, v.47, p.314-318, 1955a. 
JOHNSON, H.W.; ROBINSON, H.P.; COMSTOCK, R.E. Genotypic and phenotypic correlations in soybeans and their implications in selection. Agronomy Journal, v.47, p.477-483, 1955 b.

KIIHL, R.A.S.; ALMEIDA, L.A. Situação atual e perspectivas do melhoramento genético da soja no Brasil. In: SIMPÓSIO SOBRE A CULTURA E PRODUTIVIDADE DA SOJA, 1., Piracicaba, 1991. Anais. Piracicaba: FEALQ, 1992, p.38-40.

KWON, S.H. \& TORRIE, J.H. Heritability of and interrelationships among traits of two soybean populations. Crop Science, v.4, p.196-198, 1964.

LAM-SÁNCHEZ, A.; DURIGAN, J.F.; ASSIS, G.M. de. Respostas de genótipos de soja (Glycine max (L.) Merrill) ao retardamento de colheita quanto aos conteúdos de proteína e óleo da semente. Científica, v.17, p.121-125, 1989.

LI, F.S. Study on origin and evolution of soybean. Soybean Science, v.13, n.1, p.61-6, 1994. Resumo em CAB Abstracts on CD-ROM, 1993-94.

LIN, M.S.; NELSON, R.L. Relationship between plant height and flowering date in determinate soybean. Crop Science, v.28, n.1, p.27-30, Jan./Feb. 1988.

LOPES, A.C.A. Potencialidade de cruzamentos óctuplos de soja com ênfase na produtividade de grãos. Piracicaba, 1996. 102p. (Mestrado - Escola Superior de Agricultura "Luiz de Queiroz"(USP).

LUEDDERS, V.D. Genetic improvement in yield of soybeans. Crop Science, v.17, n.6, p.971-972, Nov./Dec. 1977.

MILLER, J.E. \& FEHR, W.R. Direct and indirect selection for protein in soybeans. Crop Science, v.19, p.101-106, 1979. 
MIRANDA, M.A.C. de. Seleção recorrente divergente para peso de sementes e porcentagem de óleo em soja com o uso de machoesterilidade genética. Piracicaba, 1994. 112p. Tese (Doutorado) - Escola Superior de Agricultura "Luiz de Queiroz", Universidade de São Paulo.

MIYASAKA, S. Evolução da cultura. In: FUNDAÇÃO CARGILL. A soja no Brasil central. 2. Ed. Campinas: 1982. p.5-20.

NAMKOONG, G. Optimum allocation of selection intensity in two stages of truncation selection. Biometrics, v. 26, p.465-76, 1970.

PACOVA, B.E.V. Análise genética de progênies segregantes de soja apropriadas para o consumo humano. Piracicaba, 1992. 217p. Tese (Doutorado) - Escola Superior de Agricultura “Luiz de Queiroz”, Universidade de São Paulo.

PIMENTEL, A.M. Cruzamentos dialélicos em soja com ênfase em teor de proteína e produção de grãos. Piracicaba, 1991. 150p. (Mestrado - Escola Superior de Agricultura "Luiz de Queiroz"(USP).

PRADO, L.C. Perspectivas para o melhoramento de linhagens homozigóticas de soja, com ênfase em produção de grãos e teor de proteína. Piracicaba, 1994. 128p. Dissertação (Mestrado) - Escola Superior de Agricultura "Luiz de Queiroz", Universidade de São Paulo.

RAMALHO, M.A.P.; SANTOS, J. B. dos.; ZIMMERMANN, M.J.O.de. Genética quantitativa em plantas autógamas: aplicações ao melhoramento do feijoeiro. Goiânia: UFG, 1993. cap.3, p.29-77: Componentes de médias, variâncias e covariâncias.

RANZANI, G.; FREIRE, O.; KINJO, T. Carta de solos do município de Piracicaba. Piracicaba, ESALQ/Centro de Estudos de Solos, 1966. 86p. (mimeografado). 
RASMUSSON, D.C.; LAMBERT, J.W. Variety $\mathrm{x}$ environment interaction in barley variety tests. . Crop Science, Madison, v.1, p.261-2. 1961.

ROMAGOSA, I.; FOX, P.N. Genotype x environment interaction and adaptation. In: Plant Breeding: Principles and prospects. Chapman \& Hall Editors. London, 1994, Chapter 20, p. 373-90.

ROSE, J.L.; BUTLER, D.G.; RYLEY, M.J. Yield improvement in soybeans using recurrent selection. Australian Journal Agricultural Research, v.43, n.1, p.135144, 1992.

SANTOS, C.A.F. Análise de trilha e estimativas de parâmetros genéticos em progênies $\mathrm{F}_{6}$ de um cruzamento de soja (Glycine max (L.) Merrill). Viçosa, 1994. 71p. Dissertação (M. S.) - Universidade Federal de Viçosa.

SEBERN, N.A. \& LAMBERT, J.W. Effect of stratification for percent protein in two soybean populations. Crop Science, v.24, p.225-228, 1984.

SHANNON, J.G.; WILCOX, J.R.; PROBST, A.H. Estimated gains from selection for protein and yield in the F4 generation of six soybean populations. Crop Science, v.12, p.824-826, 1972.

SIMPSON, A.M. Jr. \& WILCOX, J.R. Genetic and phenotypic association of agronomic characteristics in four high protein soybean population. Crop Science, v.23, p.1077-1081, 1983.

SMITH, R.R. \& WEBER, C.R. Mass selection by specific gravity for protein and oil in soybean populations. Crop Science, v.8, p.373-377, 1968.

SOUZA JÚNIOR., C.L. Componentes da variância genética e suas implicações no melhoramento vegetal. FEALQ, 134p. 1989. 
SOUZA JÚNIOR., C.L. Melhoramento de espécies de reprodução vegetativa. Piracicaba, 1995. 41p. (ESALQ/USP Departamento de Genética, Publicação Didática).

ST. MARTIN, S.K. Effective population size for the soybean improvement program in maturity groups 00 to IV. Crop Science, v.22, n.1, p. 151-152, Jan./Fev. 1982.

SUMARNO, H.; FEHR, W.R. Response to recurrent selection for yield in soybeans. Crop Science, v.22, n.2, p.295-299, Mar./Apr. 1982.

THORNE, J.C. \& FEHR, W.R. Incorporation of high-protein, exotic germplasm into soybean populations by 2- and 3-way crosses. Crop Science, v.10, p.652-655, 1970.

TOLEDO, J.F.F. Genética quantitativa das características de interesse para o melhoramento de soja; previsão e exploração do potencial genético de cruzamentos de soja. In: EMBRAPA. Centro nacional de Pesquisa de Soja. Resultados de pesquisa de soja 1987/88. Londrina, 1988. 407p. (EMBRAPA-CNPSo. Documento, 36).

TOLEDO, J.F.F.; KIIHL, R.A.S. Genética quantitativa das características de interesse para o melhoramento de soja; avaliação do potencial genético de cruzamentos de soja. In: EMBRAPA. Centro nacional de Pesquisa de Soja. Resultados de pesquisa de soja 1988/89. Londrina: 1989. p.224-231.

TOLEDO, J.F.F.; ALMEIDA, L.A.; KחHL, R.A.S.; MENOSSO, O.G. Ganho genético em soja no Estado do Paraná, via melhoramento. Pesquisa Agropecuária Brasileira, v.25, n.1, p.89-94, Jan. 1990.

VAN SANFORD, D. A.; PFEIFFER, T. W.; CORNELIUS, P. L. Selection index based on genetic correlations among environments. Crop Science, Madison, v.33, n.6, p.1244-8, 1993. 
VELLO, N.A. Ampliação da base genética do germoplasma e melhoramento da soja na ESALQ/USP. In: SIMPÓSIO SOBRE A CULTURA E PRODUTIVIDADE DA SOJA, 1, Piracicaba, 1991. Anais. Piracicaba: FEALQ, p.60-81, 1992.

VELLO, N.A.; FEHR, W.R.; BAHRENFUS, J.B. Genetic variability and agronomic performance of soybean populations developed from plant introductions. Crop Science, v.24, n.3, p.511-514, May/June 1984.

VELLO, N.A.; HIROMOTO, D.M.; AZEVEDO FILHO, A.J.B.V. Coefficient of parentage and breeding of Brazilian soybean germplasm, Revista Brasileira de Genética, v.11, n.3, p.679-697, Sept. 1988.

VERNETTI, F.J. Genética da soja - Caracteres quantitativos. In: VERNETTI, F.J. Soja: genética e melhoramento. Campinas: Fundação Cargill, 1983. p.727-740.

WEBER, C.R. \& MORTHY, B.R. Heritable and non heritable relationships and variability of oil contrast and agronomic characters in the F2 generation of soybean crosses. Agronomy Journal, v.44, p.202-209, 1952.

WEISS, M.G.; WEBER, C.R.; WILLIAMS, L.F.; PROBST, A.H. Correlation of agronomic characters and temperature with seed compositional characters in soybeans, as influenced by variety and time of planting. Agronomy Journal, v.44, p. 289-97, 1952.

WILCOX, J.R. An efficient recurrent selection breeding method for soybean. In: WORLD SOYBEAN RESEARCH CONFERENCE, 5., Chiang, 1994. Abstracts. Chiang Mai: 1994, p.1.

WRICKE, G.; WEBER, W.E. Quantitative genetics and selection in plant breeding. Walter de Gruyter, 1986. 406p. 
XIANGXUN, M.; SHUMING, W.; AIPING, L.; MINGXIANG, H. Protein and oil content of soybean seed as influenced by years and location. Soybean Genetics Newsletter, Ames, v.18, p.11 3-6. 1992.

YANG, R.C.; BAKER, R.J. Genotype-Environment interactions in two wheat crosses. Crop Science, Madison, v.31, p.83-7. 1991.

ZIMBACK, L. Cruzamentos em cadeia entre genótipos adaptados e exóticos de soja com ênfase na produção de óleo. Piracicaba, 1992. 178p. (Doutorado - Escola Superior de Agricultura "Luiz de Queiroz"/USP). 
T A B E L A S 
Tabela 5. Média da produção de grãos (PG) e da altura de plantas na maturação (AM) das linhagens dos cruzamentos (1) OC-79230 X BR80-8858, (2) BR80-8858 X BR80-14853, (3) BR80-14853 X PI-165896 e (4) BR80-14853 X PI-239235, obtidas das análises em cada um dos anos de experimentação, bem como, a média geral das linhagens de todos cruzamentos em cada ano de experimentação (Média) e a média de cada cruzamento nos três primeiros anos de avaliação (Conjunta). Dados em g/parcela e em centímetros, respectivamente.

\begin{tabular}{|c|c|c|c|c|c|c|}
\hline CARACTER & ANO & 1 & 2 & 3 & 4 & Média \\
\hline \multirow{5}{*}{$\mathbf{P} \mathbf{G}$} & $1993 / 94^{1}$ & 210,47 & 255,99 & 178,93 & 222,33 & 220,09 \\
\hline & $1994 / 95^{1}$ & 151,44 & 145,53 & 135,47 & 152,26 & 146,52 \\
\hline & $1995 / 96^{1}$ & 214,14 & 250,09 & 144,26 & 192,09 & 202,98 \\
\hline & $1997 / 98^{2}$ & 356,09 & 387,53 & 215,33 & 346,95 & 331,02 \\
\hline & Conjunta ${ }^{1}$ & 192,29 & 216,30 & 151,78 & 187,98 & 189,27 \\
\hline \multirow{5}{*}{$\mathbf{A} \mathbf{M}$} & $1993 / 94$ & 71,56 & 77,01 & 87,82 & 87,91 & 81,09 \\
\hline & 1994/95 & 57,20 & 59,51 & 68,97 & 69,41 & 63,81 \\
\hline & 1995/96 & 88,18 & 89,44 & 85,80 & 96,87 & 90,41 \\
\hline & $1997 / 98$ & 74,05 & 87,39 & 90,08 & 96,76 & 87,51 \\
\hline & Conjunta & 72,52 & 75,21 & 80,66 & 84,62 & 78,38 \\
\hline
\end{tabular}

${ }^{1}$ : Dados obtidos de uma parcela constituída por uma linha de um metro de comprimento.

2 : Dados obtidos de uma parcela constituída por uma linha de dois metros de comprimento. 
Tabela 6. Média da produção de grãos (PG) e da altura de plantas na maturação (AM) de cada genitor dos cruzamentos (1) OC-79230 X BR80-8858, (2) BR80-8858 X BR80-14853, (3) BR80-14853 X PI-165896 e (4) BR80-14853 X PI-239235, obtidas das análises em cada um dos anos de experimentação. Dados em g/parcela e em centímetros, respectivamente.

\begin{tabular}{|c|c|cccc|}
\hline CARACTER & GENITORES & $1993 / 94^{1}$ & $1994 / 95^{1}$ & $1995 / 96^{1}$ & $1997 / 98^{2}$ \\
\hline & OC-79230 & 123,82 & 166,99 & 224,08 & 296,63 \\
& BR80-8858 & 196,76 & 162,26 & 274,57 & 477,91 \\
& PR80-14853 & 192,78 & 164,53 & 214,49 & 402,11 \\
& PI-165896 & 146,73 & 79,42 & 63,95 & 31,74 \\
& PI-239235 & 219,64 & 126,58 & 143,57 & 192,37 \\
\hline \multirow{3}{*}{ AM } & OC-79230 & 68,09 & 62,25 & 82,92 & 64,65 \\
& BR80-8858 & 62,84 & 55,13 & 80,00 & 75,68 \\
& BR80-14853 & 64,89 & 59,10 & 84,14 & 80,52 \\
& PI-165896 & 100,73 & 81,33 & 83,33 & 105,41 \\
& PI-239235 & 127,71 & 75,67 & 124,33 & 121,56 \\
\hline
\end{tabular}

${ }^{1}$ : Dados obtidos de uma parcela constituída por uma linha de um metro de comprimento.

2 : Dados obtidos de uma parcela constituída por uma linha de dois metros de comprimento. 
Tabela 7. Média da produção de grãos (PG) e da altura de plantas na maturação (AM) de cada testemunha utilizada na avaliação dos cruzamentos (1) OC-79230 X BR808858, (2) BR80-8858 X BR80-14853, (3) BR80-14853 X PI-165896 e (4) BR8014853 X PI-239235, obtidas das análises em cada um dos anos de experimentação. Dados em g/parcela e em centímetros, respectivamente.

\begin{tabular}{|c|c|c|c|c|c|}
\hline CARACTER & TESTEMUNHAS & $1993 / 94^{1}$ & $1994 / 95^{1}$ & $1995 / 96^{1}$ & $1997 / 98^{2}$ \\
\hline \multirow{6}{*}{ P G } & IAC -12 & 165,33 & 170,44 & 235,92 & 332,27 \\
\hline & IAC Foscarin 31 & 176,10 & 169,09 & 236,87 & 331,54 \\
\hline & BILOXI & 201,31 & 145,77 & 164,05 & - \\
\hline & BR80-14887 & 197,37 & 130,16 & 253,29 & - \\
\hline & IAC-5 & - & 167,20 & 202,68 & 242,21 \\
\hline & IAC-8 & - & - & - & 401,63 \\
\hline \multirow{6}{*}{$\mathbf{A M}$} & IAC - 12 & 78,04 & 61,35 & 88,98 & 77,90 \\
\hline & IAC Foscarin 31 & 103,37 & 70,37 & 102,98 & 119,41 \\
\hline & BILOXI & 123,35 & 78,37 & 94,22 & - \\
\hline & BR80-14887 & 70,42 & 63,17 & 90,98 & - \\
\hline & IAC-5 & - & 52,20 & 76,88 & 63,57 \\
\hline & IAC-8 & - & - & - & 107,68 \\
\hline
\end{tabular}

${ }^{1}$ : Dados obtidos de uma parcela constituída por uma linha de um metro de comprimento.

${ }^{2}$ : Dados obtidos de uma parcela constituída por uma linha de dois metros de comprimento. 
Tabela 8. Coeficientes de variação experimental (CVe) obtidos da análise de variância dos cruzamentos (1) OC-79230 X BR80-8858, (2) BR80-8858 X BR80-14853, (3) BR80-14853 X PI-165896 e (4) BR80-14853 X PI-239235, em cada um dos anos de experimentação, bem como, a média de cada ano para os quatro cruzamentos, para os caracteres produção de grãos (PG) e altura de plantas na maturação (AM). Dados em porcentagem.

\begin{tabular}{|c|c|c|c|c|c|c|}
\hline CARACTER & ANO & 1 & 2 & 3 & 4 & Média \\
\hline \multirow{4}{*}{ P G } & 1993/94 & 28,32 & 32,85 & 37,54 & 34,98 & 33,42 \\
\hline & 1994/95 & 38,09 & 39,53 & 30,30 & 27,29 & 33,80 \\
\hline & $1995 / 96$ & 21,37 & 23,27 & 31,55 & 27,59 & 25,95 \\
\hline & $1997 / 98$ & 22,49 & 20,19 & 30,34 & 21,22 & 23,56 \\
\hline \multirow{4}{*}{ A $\mathbf{M}$} & 1993/94 & 9,11 & 11,74 & 12,59 & 11,08 & 11,13 \\
\hline & $1994 / 95$ & 12,36 & 15,20 & 11,38 & 12,60 & 12,89 \\
\hline & $1995 / 96$ & 9,58 & 10,25 & 12,45 & 10,27 & 10,64 \\
\hline & $1997 / 98$ & 10,64 & 7,41 & 8,48 & 6,12 & 8,16 \\
\hline
\end{tabular}




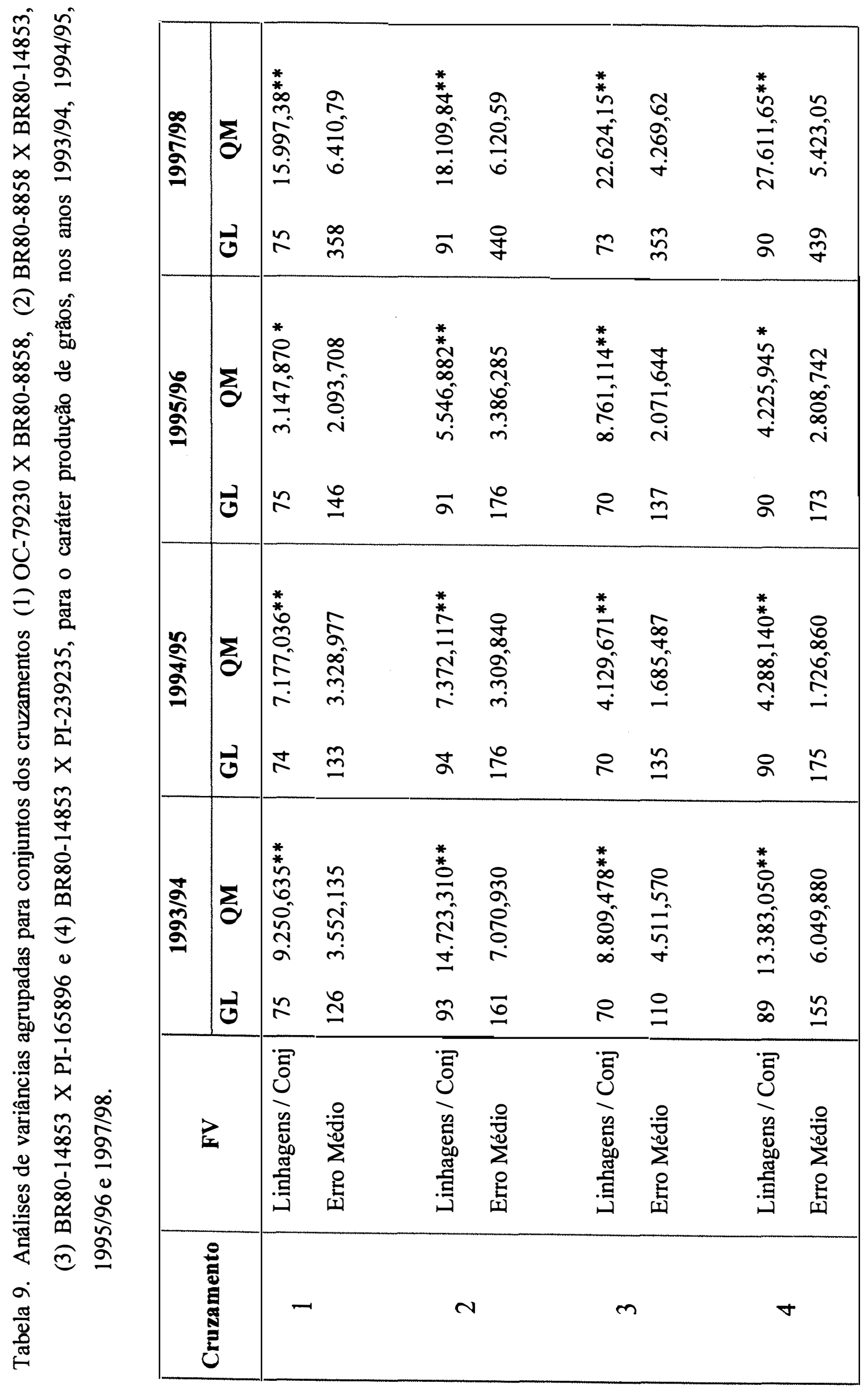




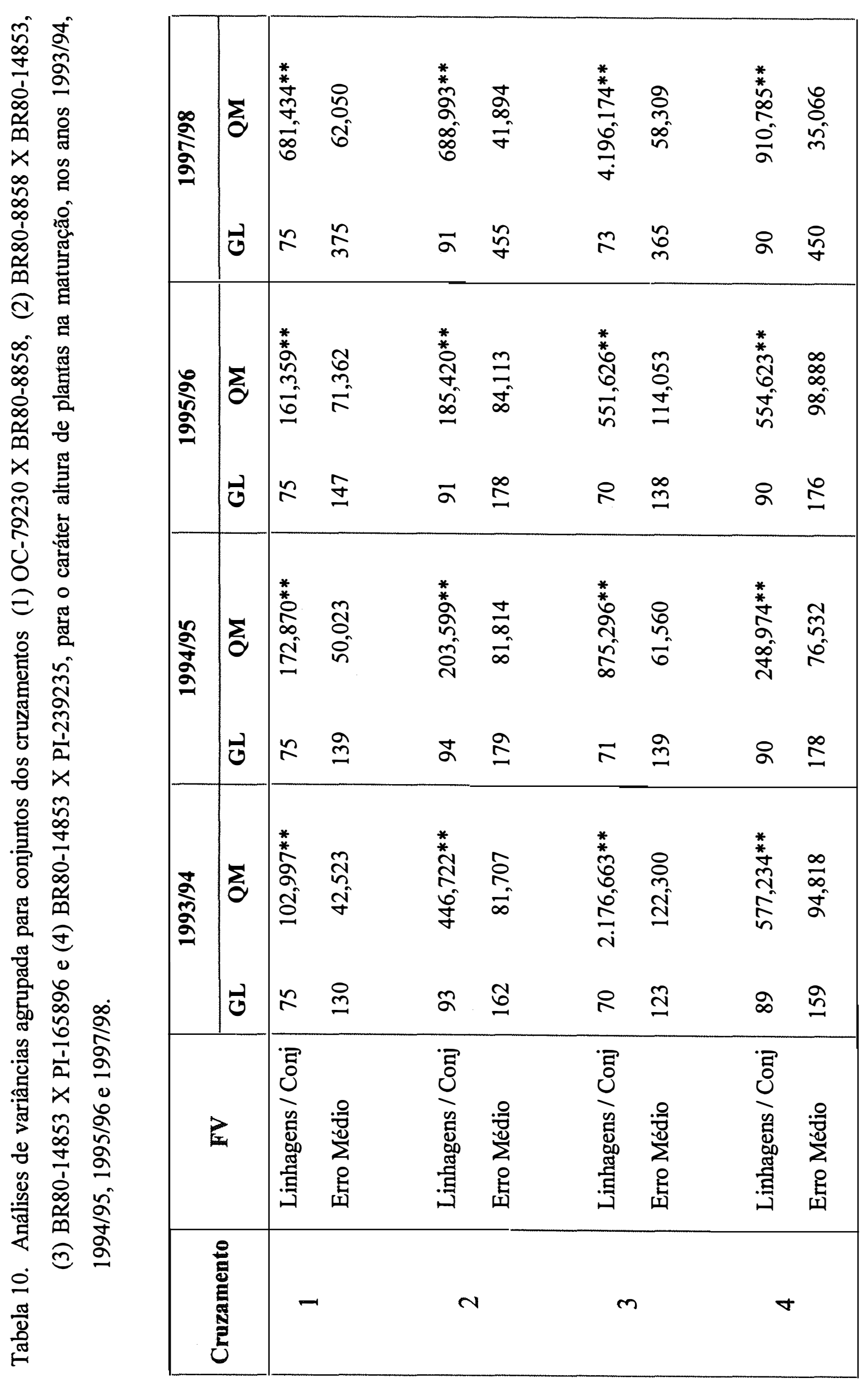




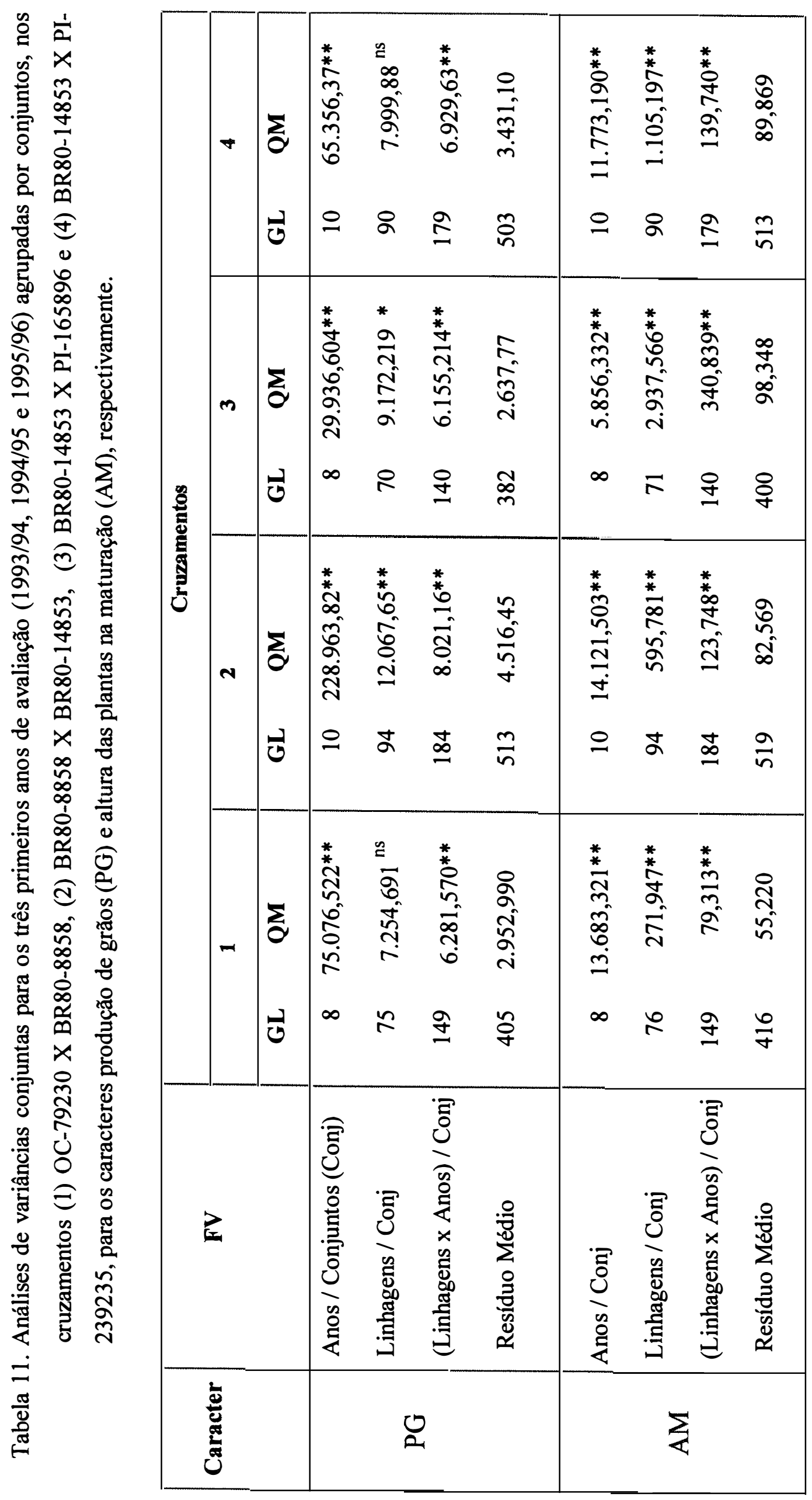


Tabela 12. Estimativas das variâncias genética aditiva entre linhagens $\left(\hat{\sigma}_{L}^{2}\right)$ e variâncias do erro experimental entre parcelas $\left(\hat{\sigma}^{2}\right)$, com seus respectivos intervalos de confiança da produção de grãos, nos cruzamentos (1) OC-79230 X BR80-8858, (2) BR80-8858 X BR80-14853, (3) BR80-14853 X PI-165896 e (4) BR80-14853 X PI-239235, para os anos 1993/94, 1994/95, 1995/96 e 1997/98.

\begin{tabular}{|c|c|c|c|c|c|}
\hline Cruzamento & Estimativas & $1993 / 94$ & $1994 / 95$ & $1995 / 96$ & $1997 / 98$ \\
\hline \multirow{6}{*}{1} & LS & $3.567,392$ & $2.736,167$ & $1.455,450$ & $3.000,714$ \\
\hline & $\hat{\sigma}_{L}^{2}$ & $1.899,499$ & $1.282,686$ & 351,387 & $1.597,765$ \\
\hline & LI & $1.178,040$ & 741,843 & 153,607 & 990,909 \\
\hline & LS & $4.622,596$ & $4.299,918$ & $2.671,083$ & $7.464,250$ \\
\hline & $\hat{\sigma}^{2}$ & $3.552,135$ & $3.328,977$ & $2.093,708$ & $6.410,790$ \\
\hline & LI & $2.815,572$ & $2.654,146$ & $1.685,644$ & $5.566,312$ \\
\hline \multirow{6}{*}{2} & LS & $5.109,948$ & $2.543,080$ & $1.962,395$ & $3.294,585$ \\
\hline & $\hat{\sigma}_{L}^{2}$ & $2.550,793$ & $1.354,092$ & 720,199 & $1.998,208$ \\
\hline & LI & $1.525,719$ & 839,787 & 370,330 & $1.340,849$ \\
\hline & LS & $8.910,542$ & $4.126,836$ & $4.222,151$ & $7.017,288$ \\
\hline & $\hat{\sigma}^{2}$ & $7.070,930$ & $3.309,840$ & $3.386,285$ & $6.120,590$ \\
\hline & LI & $5.748,869$ & $2.714,147$ & $2.776,833$ & $5.385,990$ \\
\hline \multirow{6}{*}{3} & LS & $3.563,138$ & $1.603,109$ & $3.650,511$ & $4.774,386$ \\
\hline & $\hat{\sigma}_{L}^{2}$ & $1.432,636$ & 814,728 & $2.229,823$ & $3.059,088$ \\
\hline & LI & 767,905 & 492,141 & $1.503,032$ & $2.127,352$ \\
\hline & LS & $5.988,786$ & $2.172,662$ & $2.665,157$ & $4.976,773$ \\
\hline & $\hat{\sigma}^{2}$ & $4.511,570$ & $1.685,487$ & $2.071,644$ & $4.269,620$ \\
\hline & LI & $3.521,738$ & $1.345,949$ & $1.656,889$ & $3.703,635$ \\
\hline \multirow{6}{*}{4} & LS & $4.730,696$ & $1.525,389$ & $1.733,582$ & $5.521,826$ \\
\hline & $\hat{\sigma}_{L}^{2}$ & $2.444,390$ & 853,760 & 472,401 & $3.698,100$ \\
\hline & LI & $1.490,330$ & 545,197 & 215,524 & $2.650,166$ \\
\hline & LS & $7.659,765$ & $2.154,543$ & $3.509,102$ & $6.232,249$ \\
\hline & $\hat{\sigma}^{2}$ & $6.049,880$ & $1.726,860$ & $2.808,742$ & $5.423,050$ \\
\hline & LI & $4.900,301$ & $1.415,300$ & $2.299,491$ & $4.771,496$ \\
\hline
\end{tabular}


Tabela 13. Estimativas das variâncias genética aditiva entre linhagens $\left(\hat{\sigma}_{L}^{2}\right)$ e variâncias do erro experimental entre parcelas $\left(\hat{\sigma}^{2}\right)$, com seus respectivos intervalos de confiança da altura de plantas na maturação, nos cruzamentos (1) OC-79230 X BR80-8858, (2) BR80-8858 X BR80-14853, (3) BR80-14853 X PI-165896 e (4) BR80-14853 X PI-239235, para os anos 1993/94, 1994/95, 1995/96 e 1997/98.

\begin{tabular}{|c|c|c|c|c|c|}
\hline Cruzamento & Estimativas & $1993 / 94$ & $1994 / 95$ & 1995/96 & $1997 / 98$ \\
\hline \multirow{6}{*}{1} & LS & 39,012 & 69,093 & 61,264 & 151,932 \\
\hline & $\hat{\sigma}_{L}^{2}$ & 20,158 & 40,949 & 29,999 & 103,231 \\
\hline & LI & 12,290 & 27,080 & 17,756 & 74,723 \\
\hline & LS & 55,098 & 64,230 & 90,961 & 71,985 \\
\hline & $\hat{\sigma}^{2}$ & 42,523 & 50,023 & 71,362 & 62,050 \\
\hline & LI & 33,820 & 40,069 & 57,494 & 54,045 \\
\hline \multirow{6}{*}{2} & LS & 179,696 & 71,751 & 64,346 & 150,963 \\
\hline & $\hat{\sigma}_{L}^{2}$ & 121,672 & 40,595 & 33,769 & 107,850 \\
\hline & LI & 87,859 & 26,091 & 20,770 & 80,916 \\
\hline & LS & 102,887 & 101,809 & 104,737 & 47,919 \\
\hline & $\hat{\sigma}^{2}$ & 81,707 & 81,814 & 84,113 & 41,894 \\
\hline & LI & 66,470 & 67,196 & 69,048 & 36,942 \\
\hline \multirow{6}{*}{3} & LS & $1.007,853$ & 400,600 & 234,156 & 987,352 \\
\hline & $\hat{\sigma}_{L}^{2}$ & 684,788 & 271,245 & 145,858 & 689,644 \\
\hline & LI & 495,678 & 195,866 & 99,569 & 509,047 \\
\hline & LS & 159,700 & 79,044 & 146,587 & 67,787 \\
\hline & $\hat{\sigma}^{2}$ & 122,300 & 61,560 & 114,053 & 58,309 \\
\hline & LI & 96,684 & 49,310 & 91,289 & 50,695 \\
\hline \multirow{6}{*}{4} & LS & 237,492 & 93,464 & 225,154 & 202,944 \\
\hline & $\hat{\sigma}_{L}^{2}$ & 160,805 & 57,481 & 151,912 & 145,953 \\
\hline & LI & 116,117 & 38,915 & 109,423 & 110,038 \\
\hline & LS & 119,670 & 95,298 & 123,297 & 40,140 \\
\hline & $\hat{\sigma}^{2}$ & 94,818 & 76,532 & 98,888 & 35,066 \\
\hline & LI & 76,995 & 62,825 & 81,090 & 30,900 \\
\hline
\end{tabular}


Tabela 14. Estimativas das variâncias genética aditiva entre linhagens $\left(\hat{\sigma}_{L}^{2}\right)$, variâncias da interação de linhagens com anos $\left(\hat{\sigma}_{L \times A}^{2}\right)$, variâncias do erro experimental entre parcelas $\left(\hat{\sigma}^{L}\right)$, com seus respectivos intervalos de confiança da produção de grãos (PG) e da altura de plantas na maturação (AM) dos cruzamentos (1) OC-79230 X BR80-8858, (2) BR80-8858 X BR80-14853, (3) BR80-14853 X PI-165896 e (4) BR80-14853 X PI-239235, obtidas das análises de variância conjuntas dos anos 1993/94, 1994/95 e 1995/96.

\begin{tabular}{|c|c|c|c|c|c|}
\hline \multirow[b]{2}{*}{ Caracter } & \multirow{2}{*}{ Estimativas } & \multicolumn{4}{|c|}{ Cruzamento } \\
\hline & & 1 & 2 & 3 & 4 \\
\hline \multirow{9}{*}{$\mathrm{PG}$} & LS & $108.124,56$ & $1.498,700$ & $1.625,980$ & $118.916,67$ \\
\hline & $\hat{\sigma}_{L}^{2}$ & 108,125 & 449,610 & 335,223 & 118,917 \\
\hline & LI & 21,522 & 212,716 & 139,202 & 23,670 \\
\hline & LS & $1.829,354$ & $2.043,823$ & $1.882,274$ & $1.883,896$ \\
\hline & $\hat{\sigma}_{I x A}^{2}$ & $1.109,527$ & $1.168,237$ & $1.172,481$ & $1.166,177$ \\
\hline & LI & 744,521 & 755,529 & 800,392 & 792,842 \\
\hline & LS & $3.405,976$ & $5.124,440$ & $3.055,789$ & $3.898,009$ \\
\hline & $\hat{\sigma}^{2}$ & $2.952,990$ & $4.516,450$ & $2.637,770$ & $3.431,100$ \\
\hline & LI & $2.585,018$ & $4.010,960$ & $2.300,295$ & $3.043,617$ \\
\hline \multirow{9}{*}{ A M } & LS & 35,825 & 78,313 & 435,982 & 154,900 \\
\hline & $\hat{\sigma}_{L}^{2}$ & 21,404 & 52,448 & 288,525 & 107,273 \\
\hline & LI & 14,226 & 37,585 & 205,075 & 78,699 \\
\hline & LS & 21,883 & 30,017 & 116,378 & 34,665 \\
\hline & $\hat{\sigma}_{L \times A}^{2}$ & 8,031 & 13,726 & 80,830 & 16,624 \\
\hline & LI & 4,130 & 7,837 & 59,423 & 9,730 \\
\hline & LS & 63,566 & 93,613 & 113,539 & 101,967 \\
\hline & $\hat{\sigma}^{2}$ & 55,220 & 82,569 & 98,348 & 89,869 \\
\hline & LI & 48,422 & 73,377 & 86,024 & 79,811 \\
\hline
\end{tabular}


Tabela 15. Estimativas dos coeficientes de variação genético (CVg) dos cruzamentos (1) OC-79230 X BR80-8858, (2) BR80-8858 X BR80-14853, (3) BR80-14853 X PI165896 e (4) BR80-14853 X PI-239235, em cada um dos anos de experimentação e das análises conjuntas dos três primeiros anos; dos caracteres produção de grãos (PG) e altura de plantas na maturação (AM). Dados em porcentagem.

\begin{tabular}{|c|c|c|c|c|c|}
\hline CARACTER & ANO & 1 & 2 & 3 & 4 \\
\hline \multirow{5}{*}{$\mathbf{P} \mathbf{G}$} & 1993/94 & 20,71 & 19,73 & 21,15 & 22,24 \\
\hline & 1994/95 & 23,65 & 25,29 & 21,07 & 19,19 \\
\hline & $1995 / 96$ & 8,75 & 10,73 & 32,73 & 11,31 \\
\hline & 1997/98 & 11,23 & 11,53 & 25,69 & 17,53 \\
\hline & Conjunta & 5,41 & 9,80 & 12,06 & 5,80 \\
\hline \multirow{5}{*}{$\mathbf{A} \mathbf{M}$} & 1993/94 & 6,27 & 14,32 & 29,80 & 14,42 \\
\hline & 1994/95 & 11,19 & 10,71 & 23,88 & 10,92 \\
\hline & 1995/96 & 6,21 & 6,50 & 14,08 & 12,72 \\
\hline & $1997 / 98$ & 13,72 & 11,88 & 29,15 & 12,49 \\
\hline & Conjunta & 6,38 & 9,63 & 21,06 & 12,24 \\
\hline
\end{tabular}


Tabela 16. Estimativas dos coeficientes de herdabilidade entre médias de progênies $\left(h_{x}^{2}\right)$ e seus respectivos intervalos de confiança, dos cruzamentos (1) OC-79230 X BR808858, (2) BR80-8858 X BR80-14853, (3) BR80-14853 X PI-165896 e (4) BR8014853 X PI-239235, em cada um dos anos de experimentação, bem como, das análises conjuntas dos três primeiros anos para os caracteres produção de grảos (PG) e altura de plantas na maturação (AM). Dados em porcentagem.

\begin{tabular}{|c|c|c|c|c|c|c|c|}
\hline Caracter & Cruzamento & Estimativas & 1993/94 & $1994 / 95$ & $1995 / 96$ & $1997 / 98$ & Conjunta \\
\hline & & $\begin{array}{l}\text { LS } \\
h_{x}^{2} \\
\mathbf{L I}\end{array}$ & $\begin{array}{l}74,16 \\
61,60 \\
41,71\end{array}$ & $\begin{array}{l}68,68 \\
53,62 \\
29,66\end{array}$ & $\begin{array}{r}54,67 \\
33,49 \\
-0,12\end{array}$ & $\begin{array}{l}71,29 \\
59,93 \\
41,70\end{array}$ & $\begin{array}{r}40,89 \\
13,41 \\
-30,20\end{array}$ \\
\hline & & $\begin{array}{l}\mathbf{L S} \\
h_{\bar{x}}^{2} \\
\mathbf{L I}\end{array}$ & $\begin{array}{l}66,29 \\
51,97 \\
30,35\end{array}$ & $\begin{array}{l}68,24 \\
55,10 \\
35,28\end{array}$ & $\begin{array}{l}56,95 \\
38,95 \\
11,60\end{array}$ & $\begin{array}{l}75,05 \\
66,20 \\
52,61\end{array}$ & $\begin{array}{r}52,83 \\
33,53 \\
4,40\end{array}$ \\
\hline & & $\begin{array}{l}\mathbf{L S} \\
h_{x}^{2} \\
\mathbf{L I}\end{array}$ & $\begin{array}{l}66,23 \\
48,79 \\
20,72\end{array}$ & $\begin{array}{l}72,57 \\
59,19 \\
37,60\end{array}$ & $\begin{array}{l}84,09 \\
76,35 \\
63,88\end{array}$ & $\begin{array}{l}86,53 \\
81,13 \\
72,41\end{array}$ & $\begin{array}{r}54,76 \\
32,89 \\
-2,39\end{array}$ \\
\hline & & $\begin{array}{l}\mathbf{L S} \\
h_{x}^{2} \\
\mathbf{L I}\end{array}$ & $\begin{array}{l}68,50 \\
54,79 \\
33,89\end{array}$ & $\begin{array}{l}71,64 \\
59,73 \\
41,58\end{array}$ & $\begin{array}{r}53,24 \\
33,54 \\
3,52\end{array}$ & $\begin{array}{l}85,52 \\
80,36 \\
72,42\end{array}$ & $\begin{array}{r}38,90 \\
13,38 \\
-25,52\end{array}$ \\
\hline & & $\begin{array}{l}\mathbf{L S} \\
h_{x}^{2} \\
\mathbf{L I}\end{array}$ & $\begin{array}{l}72,14 \\
58,71 \\
37,44\end{array}$ & $\begin{array}{l}80,36 \\
71,06 \\
56,32\end{array}$ & $\begin{array}{l}69,84 \\
55,77 \\
33,45\end{array}$ & $\begin{array}{l}93,47 \\
90,89 \\
86,77\end{array}$ & $\begin{array}{l}80,06 \\
70,84 \\
56,24\end{array}$ \\
\hline & 2 & $\begin{array}{l}\mathbf{L S} \\
h_{x}^{2} \\
\mathbf{L I}\end{array}$ & $\begin{array}{l}87,15 \\
81,71 \\
73,48\end{array}$ & $\begin{array}{l}71,54 \\
59,82 \\
42,12\end{array}$ & $\begin{array}{l}67,98 \\
54,64 \\
34,35\end{array}$ & $\begin{array}{l}95,51 \\
93,92 \\
91,48\end{array}$ & $\begin{array}{l}85,26 \\
79,23 \\
70,13\end{array}$ \\
\hline & 3 & $\begin{array}{l}\mathbf{L S} \\
h_{x}^{2} \\
\mathbf{L I}\end{array}$ & $\begin{array}{l}96,25 \\
94,38 \\
91,36\end{array}$ & $\begin{array}{l}95,25 \\
92,97 \\
89,29\end{array}$ & $\begin{array}{l}86,08 \\
79,32 \\
68,42\end{array}$ & $\begin{array}{l}99,01 \\
98,61 \\
97,97\end{array}$ & $\begin{array}{l}92,17 \\
88,40 \\
82,34\end{array}$ \\
\hline & 4 & $\begin{array}{l}\mathbf{L S} \\
h_{\frac{2}{x}}^{2} \\
\mathbf{L I}\end{array}$ & $\begin{array}{l}88,53 \\
83,57 \\
76,01\end{array}$ & $\begin{array}{l}78,33 \\
69,26 \\
55,44\end{array}$ & $\begin{array}{l}87,44 \\
82,17 \\
74,14\end{array}$ & $\begin{array}{l}97,16 \\
96,15 \\
94,60\end{array}$ & $\begin{array}{l}91,08 \\
87,36 \\
81,68\end{array}$ \\
\hline
\end{tabular}




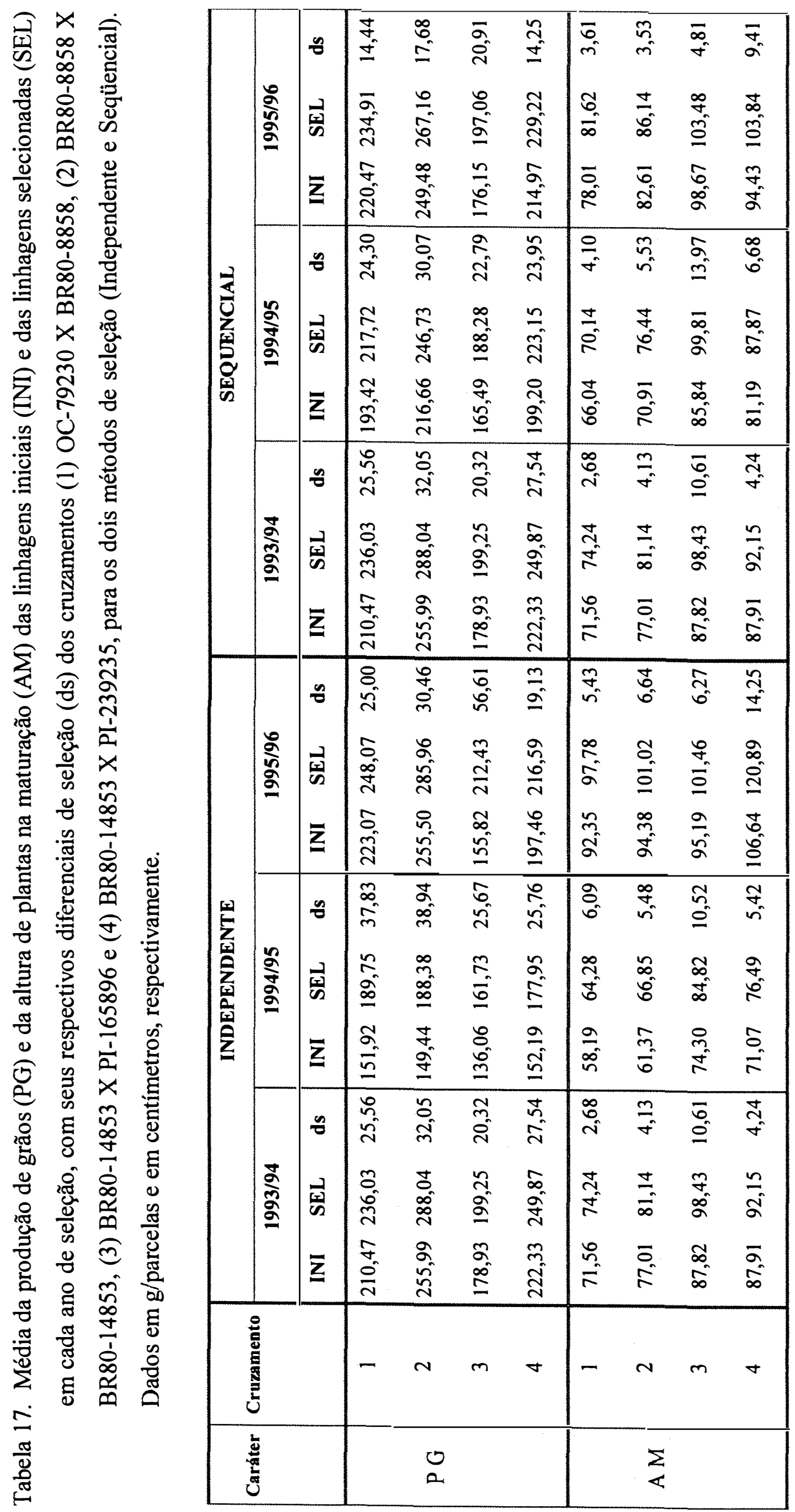




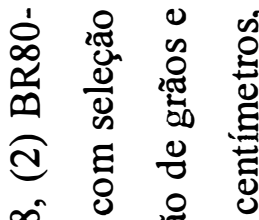

年

○े 敢 는

舀

×

잉 n 0 की

กิ ฏ ํํํ ह

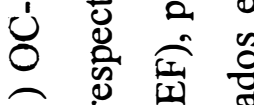

己

\& 0 జ

䒕

งึ

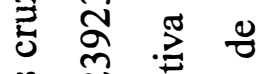

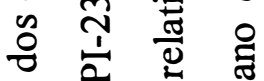

ค

四

急

.ำ 㐘 :

\& Ð

范

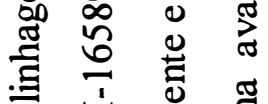

它 戛

$\begin{array}{lll}0 & x & 0 \\ 0 & m & 0 \\ 0\end{array}$

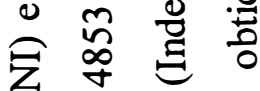

党

ฮี

๘

ఫี

용 욤

:

$\sum_{i}^{\infty} i_{\infty}^{\infty} \underset{\infty}{0}$

$\infty$

$\frac{\pi}{\pi}$

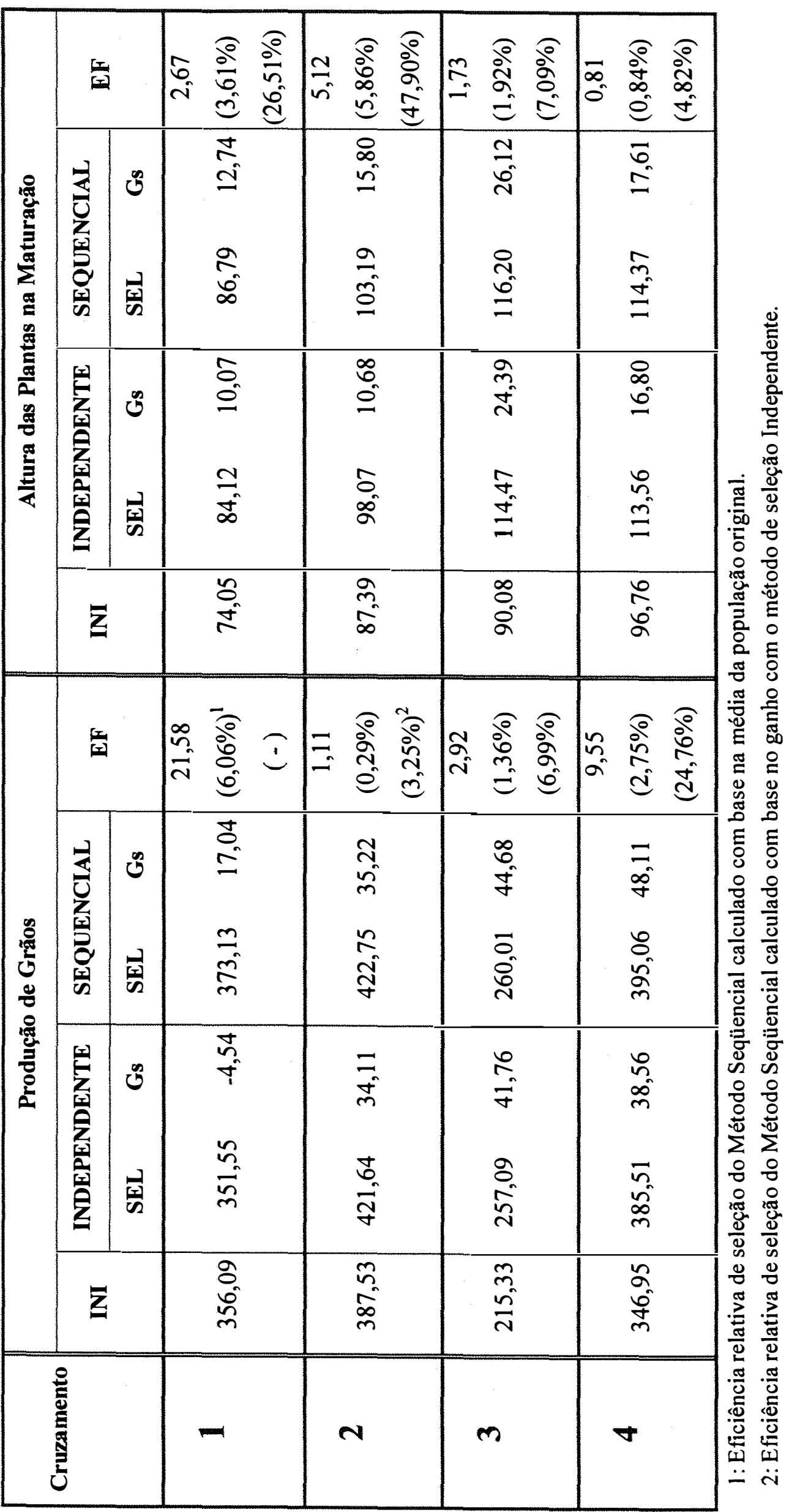




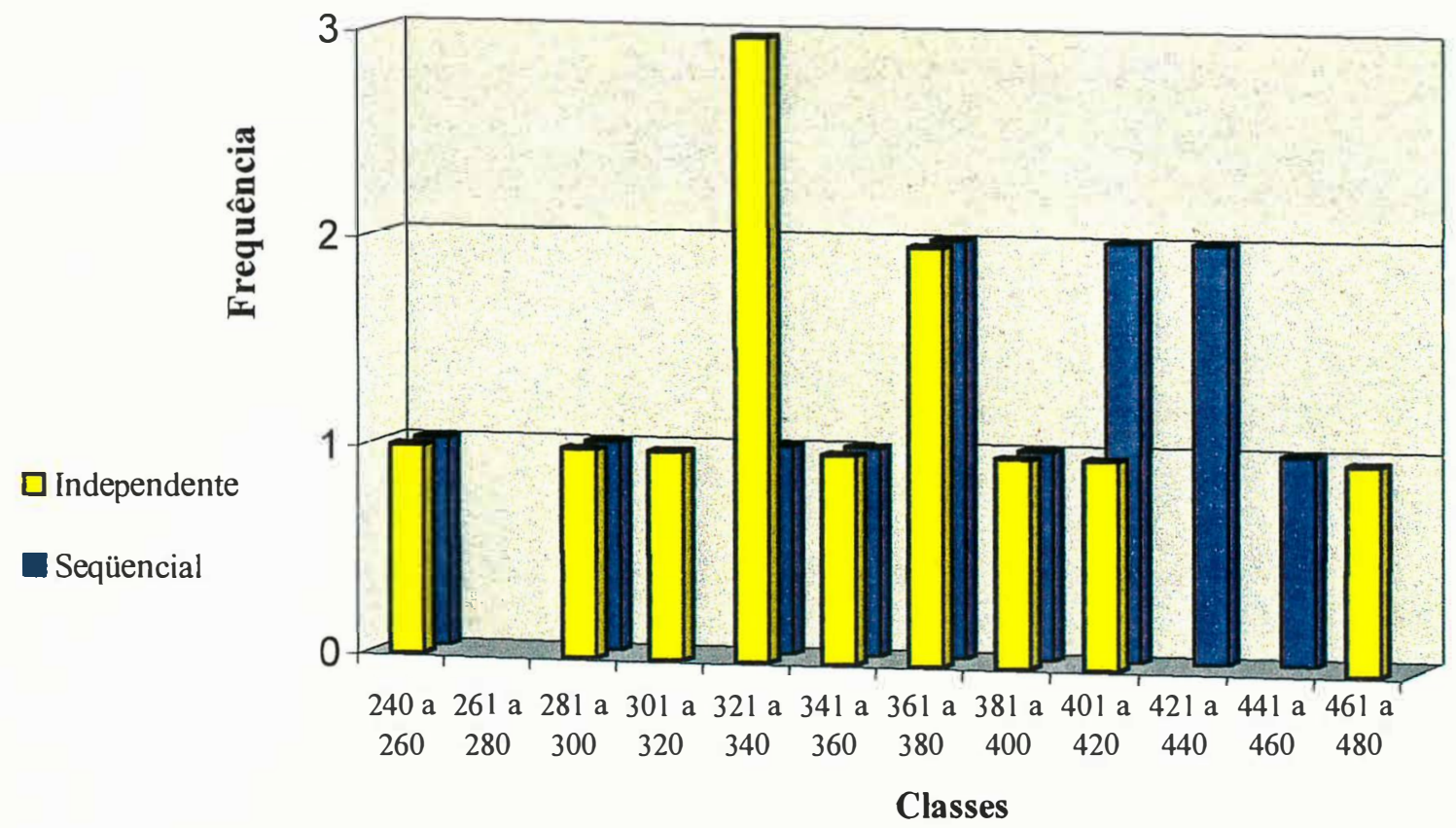

Figura 1. Freqüência de linhagens selecionadas no cruzamento OC-79230 X BR80-8858 pelos dois métodos de seleção (Independente e Seqüencial), divididas em classes de distribuição, para o caráter produção de grãos na avaliação do ano 1997/98, dados em gramas.

$\square$ Independente

Seqüencial

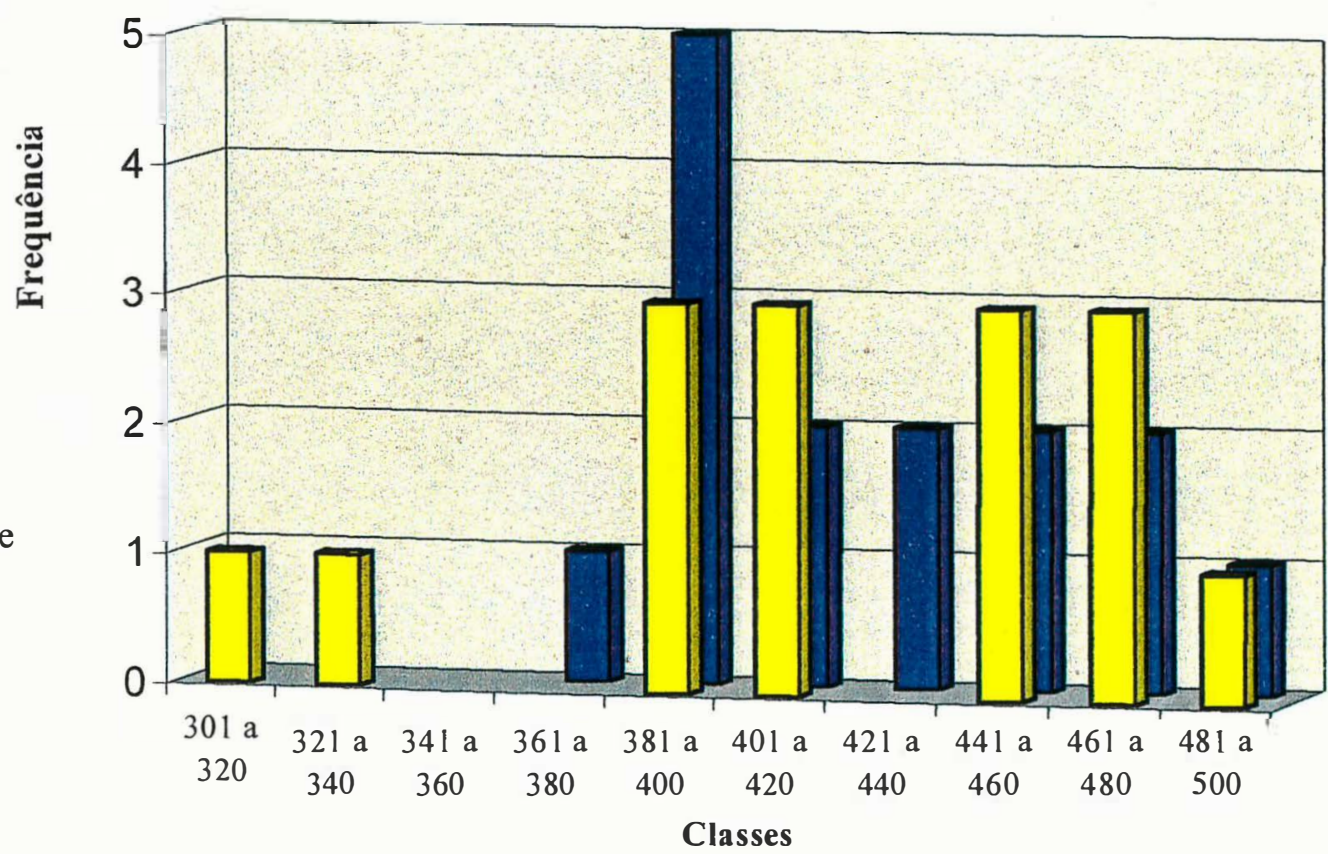

Figura 2. Freqüência de linhagens selecionadas no cruzamento BR80-8858 X BR80-14853 pelos dois métodos de seleção (Independente e Seqüencial), divididas em classes de distribuição, para o caráter produção de grãos na avaliação do ano 1997/98, dados em gramas. 


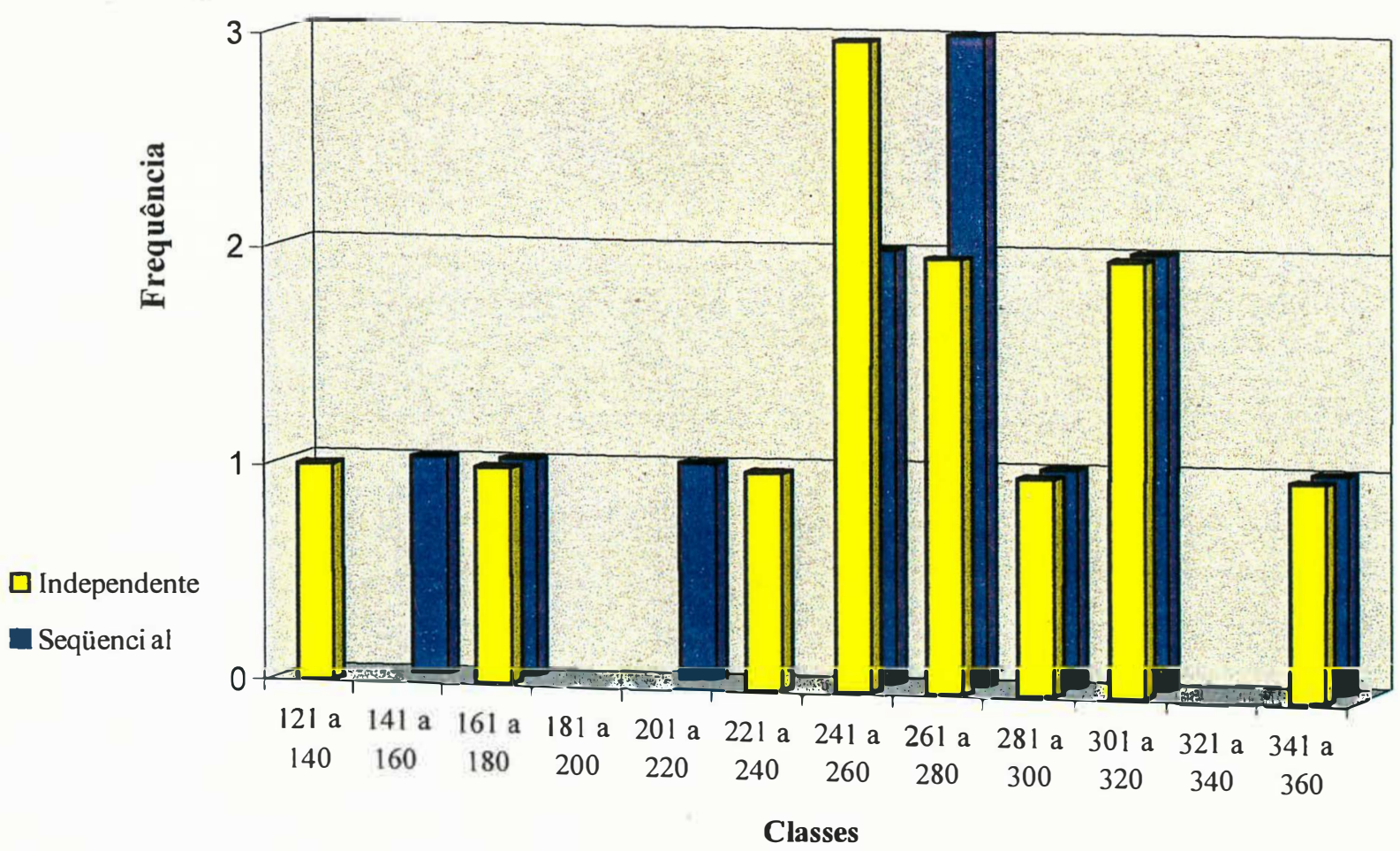

Figura 3. Freqüência de linhagens selecionadas no cruzamento BR80-14853 X PI-165896 pelos dois métodos de seleção (Independente e Seqüencial), divididas em classes de distribuição, para o caráter produção de grãos na avaliação do ano 1997/98, dados em gramas.

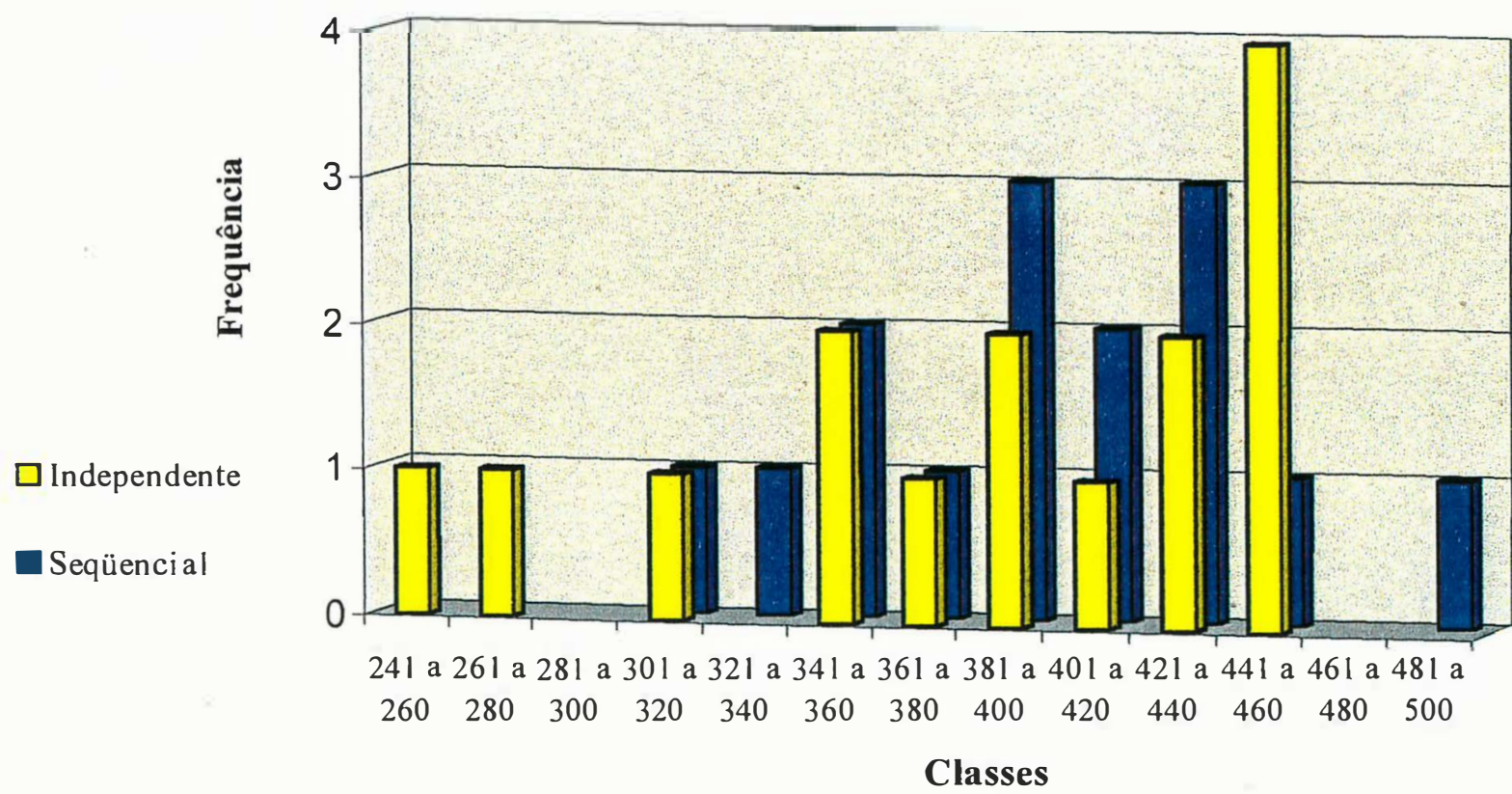

Figura 4. Freqüência de linhagens selecionadas no cruzamento BR80-14853 X PI-239235 pelos dois métodos de seleção (Independente e Seqüencial), divididas em classes de distribuição, para o caráter produção de grãos na avaliação do ano 1997/98, dados em gramas. 


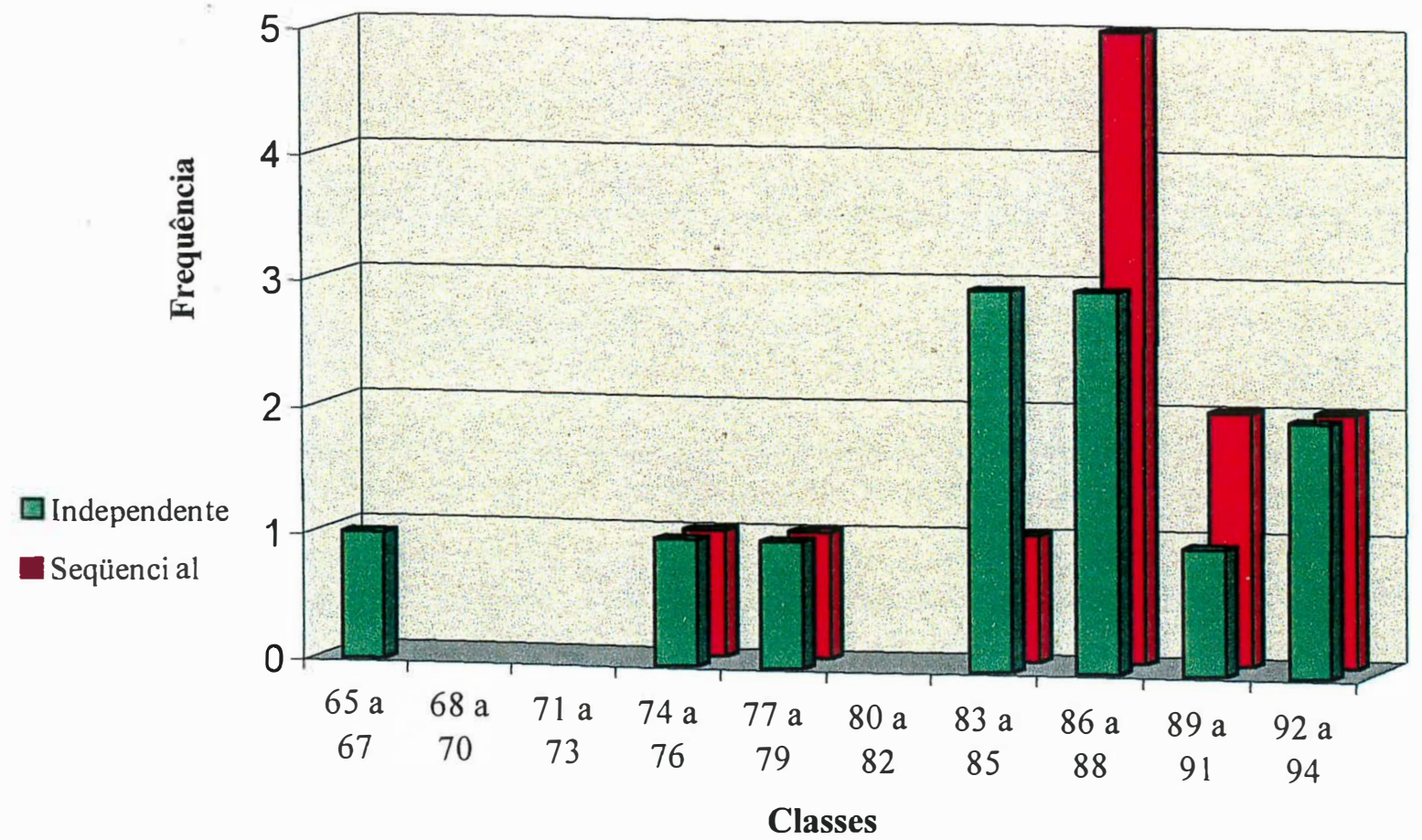

Figura 5. Freqüência de linhagens selecionadas no cruzamento OC-79230 X BR80-8858 pelos dois métodos de seleção (Independente e Seqüencial), divididas em classes de distribuição, para o caráter altura de plantas na maturação na avaliação do ano 1997/98, dados em centímetros.

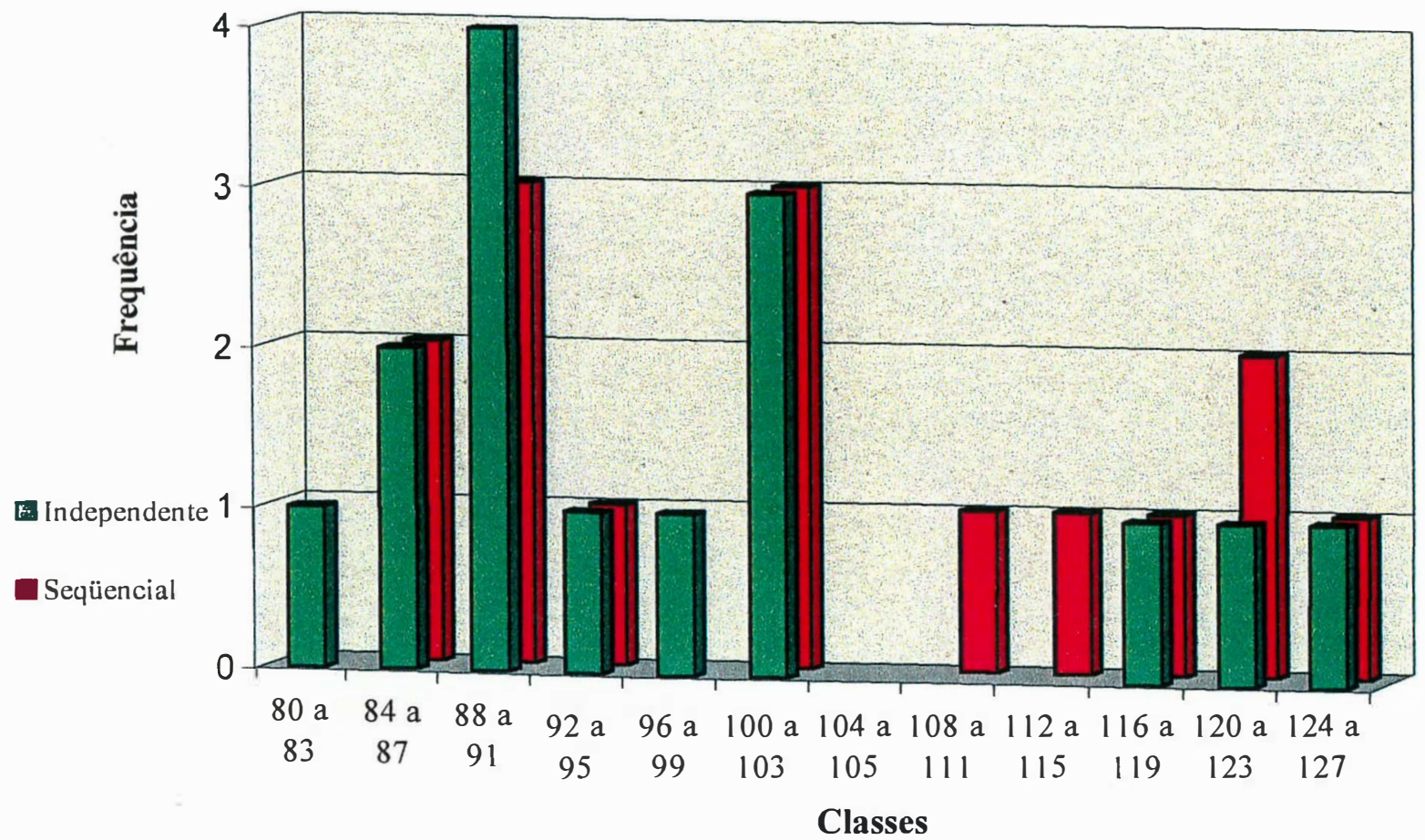

Figura 6. Freqüência de linhagens selecionadas no cruzamento BR80-8858 X BR80-14853 pelos dois métodos de seleção (Independente e Seqüencial), divididas em classes de distribuição, para o caráter altura de plantas na maturação na avaliação do ano 1997/98, dados em centímetros. 


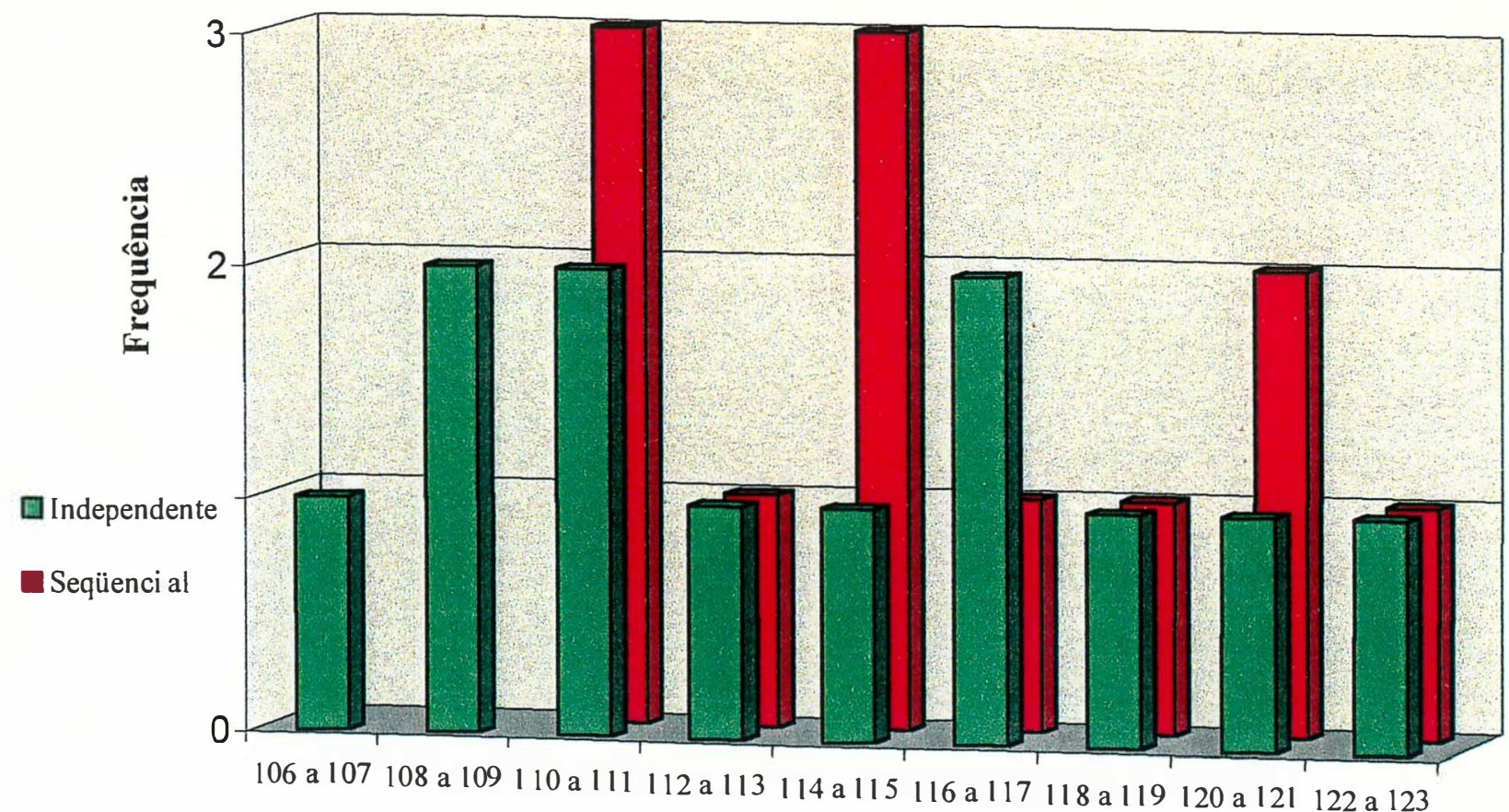

\section{Classes}

Figura 7. Freqüêncià de linhagens selecionadas no cruzamento BR80-14853 X PI-165896 pelos dois métodos de seleção (Independente e Seqüencial), divididas em classes de distribuição, para o caráter altura de plantas na maturação na avaliação do ano 1997/98, dados em centímetros.

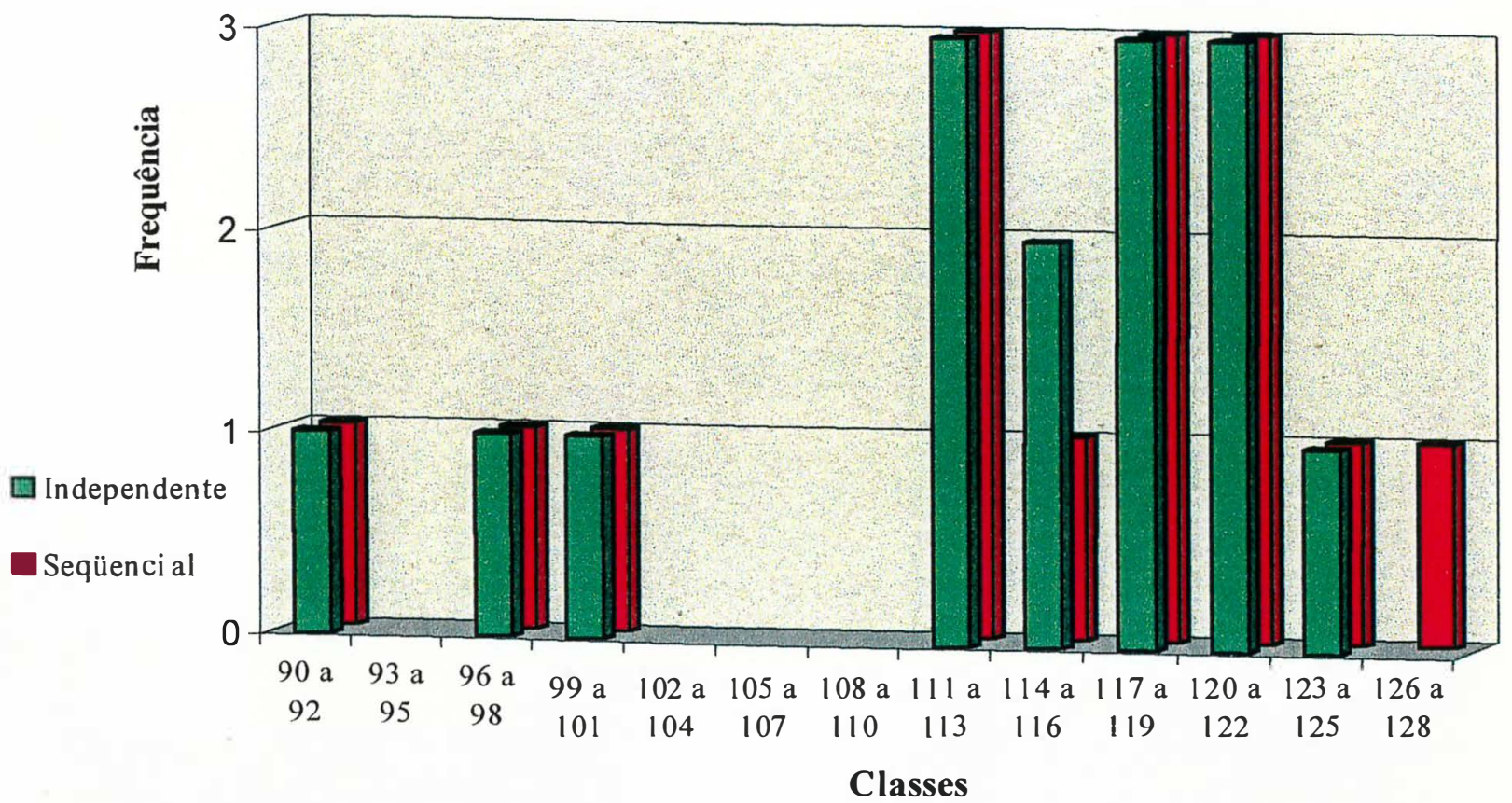

Figura 8. Freqüência de linhagens selecionadas no cruzamento BR80-14853 X PI-239235 pelos dois métodos de seleção (Independente e Seqüencial), divididas em classes de distribuição, para o caráter altura de plantas na maturação na avaliação do ano 1997/98, dados em centímetros. 